\title{
A Satellite Model of Southwestern Willow Flycatcher (Empidonax traillii extimus) Breeding Habitat and a Simulation of Potential Effects of Tamarisk Leaf Beetles (Diorhabda spp.), Southwestern United States
}

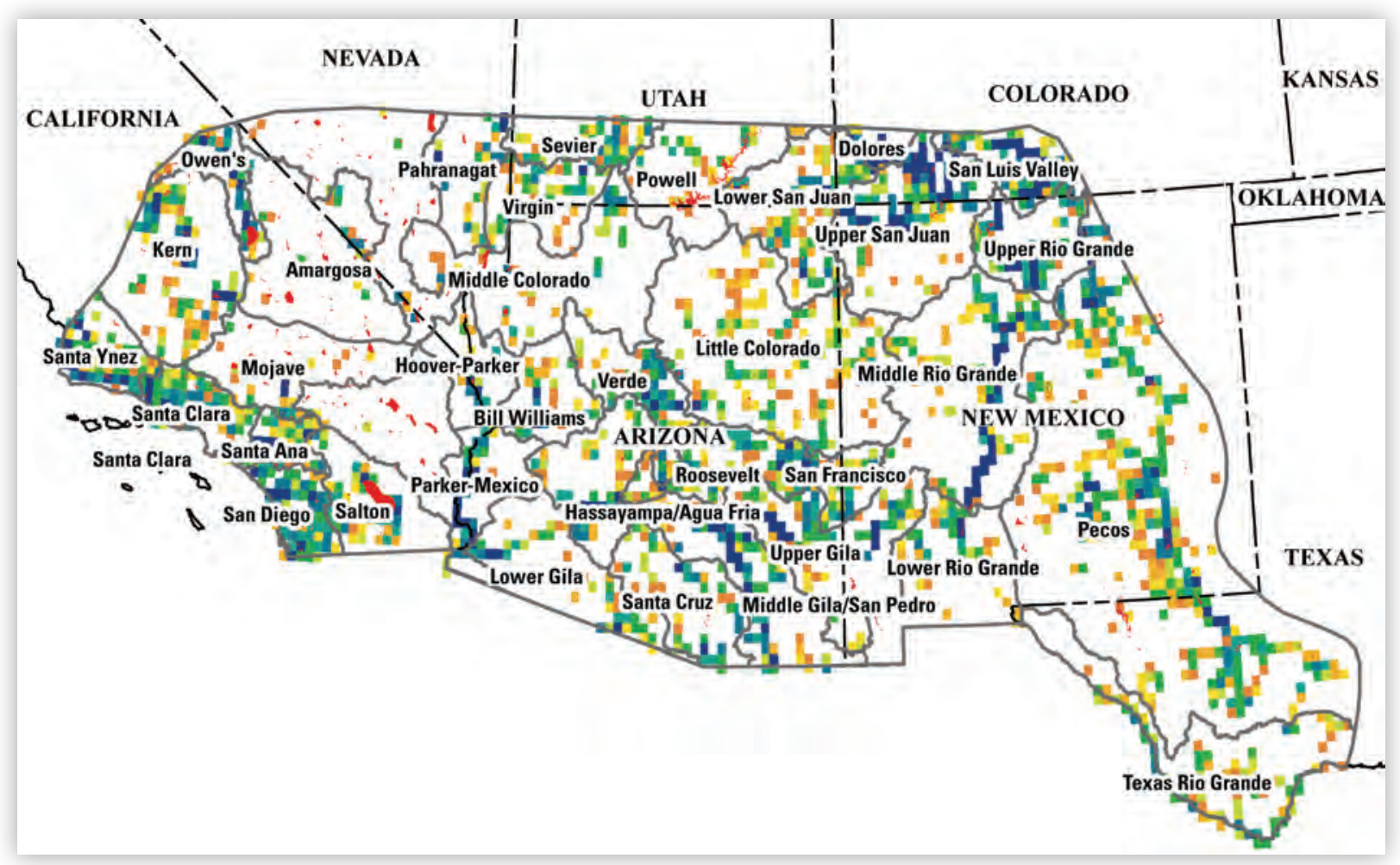

Open-File Report 2016-1120 



\section{A Satellite Model of Southwestern Willow Flycatcher (Empidonax traillii extimus) Breeding Habitat and a Simulation of Potential Effects of Tamarisk Leaf Beetles (Diorhabda spp.), Southwestern United States}

By James R. Hatten

Open-File Report 2016-1120

U.S. Department of the Interior

U.S. Geological Survey 


\section{U.S. Department of the Interior \\ SALLY JEWELL, Secretary}

\section{U.S. Geological Survey \\ Suzette M. Kimball, Director}

U.S. Geological Survey, Reston, Virginia: 2016

For more information on the USGS—-the Federal source for science about the Earth,

its natural and living resources, natural hazards, and the environment-visit

http://www.usgs.gov/ or call 1-888-ASK-USGS (1-888-275-8747).

For an overview of USGS information products, including maps, imagery, and publications, visit http://www.http://www.store.usgs.gov.

Any use of trade, firm, or product names is for descriptive purposes only and does not imply endorsement by the U.S. Government.

Although this information product, for the most part, is in the public domain, it also may contain copyrighted materials as noted in the text. Permission to reproduce copyrighted items must be secured from the copyright owner.

\section{Suggested citation:}

Hatten, J.R., 2016, A satellite model of Southwestern Willow Flycatcher (Empidonax traillii extimus) breeding habitat and a simulation of potential effects of tamarisk leaf beetles (Diorhabda spp.), Southwestern United States: U.S. Geological Survey Open-File Report 2016-1120, 88 p., http://dx.doi.org/10.3133/ofr20161120.

ISSN 2331-1258 (online)] 


\section{Contents}

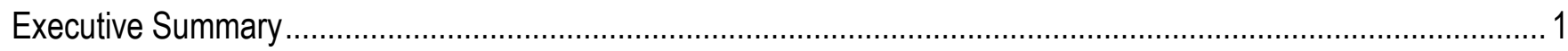

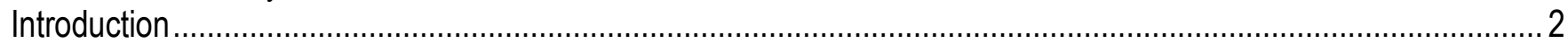

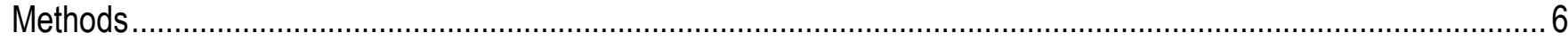

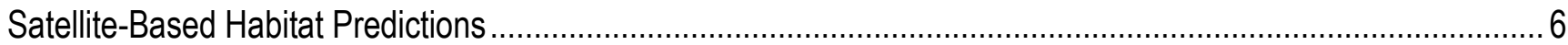

Geospatial Database

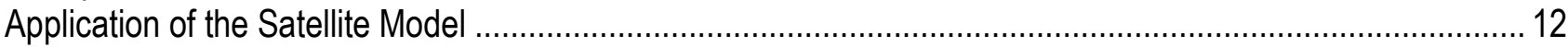

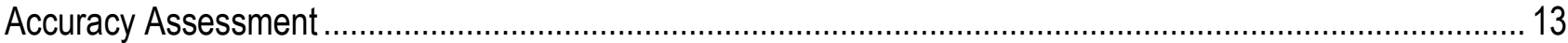

Summarization and Display of Model Results ………………............................................................ 14

Habitat Change Detection ........................................................................................................... 14

Tamarisk Leaf Beetle Impact Assessment ........................................................................................... 14

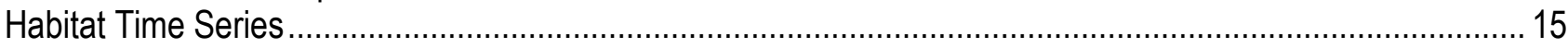

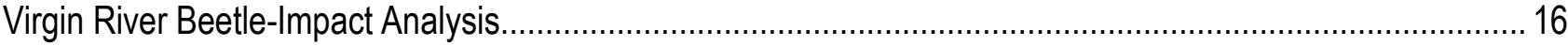

Lower Colorado River Beetle-Impact Simulation .................................................................................. 18

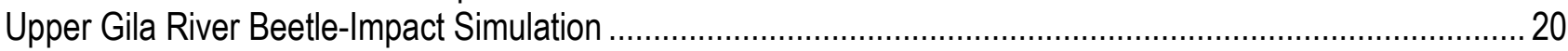

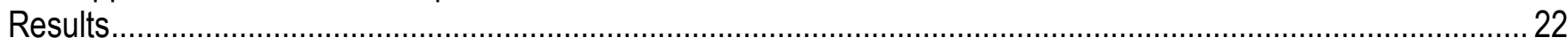

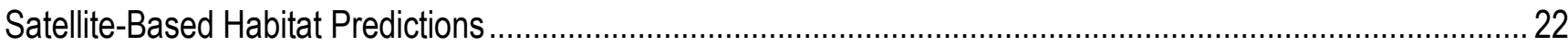

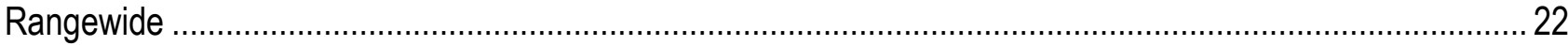

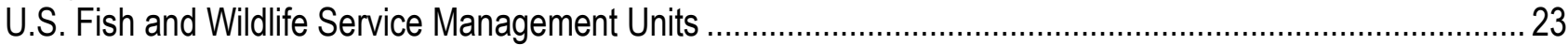

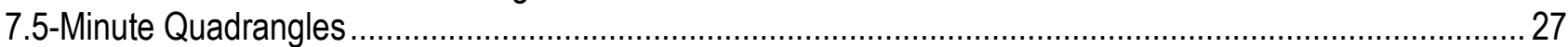

U.S. Fish and Wildlife Service Critical-Habitat Reaches.......................................................................... 32

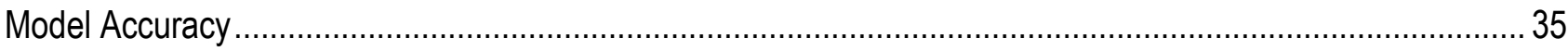

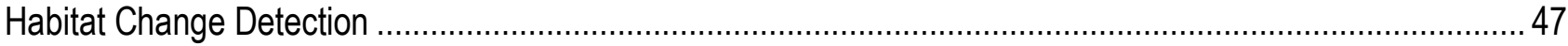

Tamarisk Leaf Beetle Impact Assessment ............................................................................................. 51

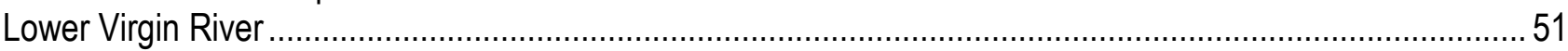

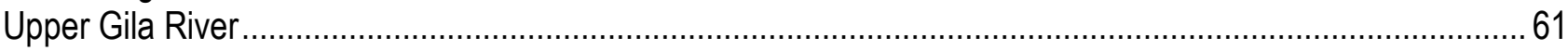

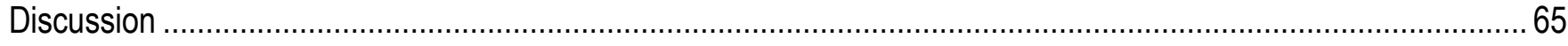

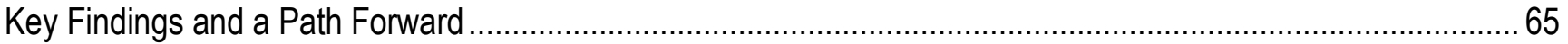

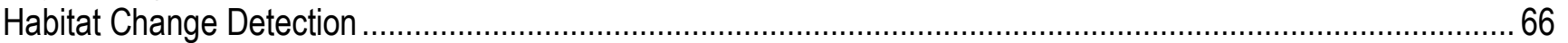

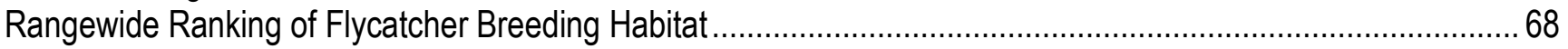

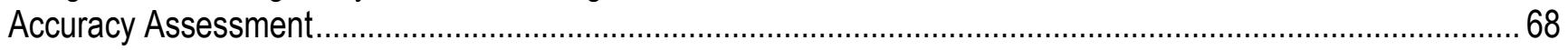

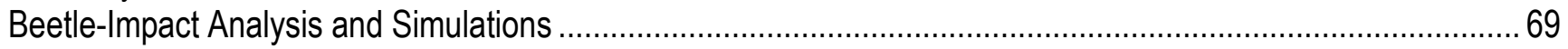

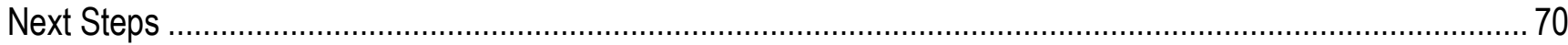

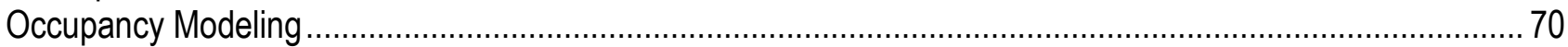

Automated Cloud-Based Mapping......................................................................................................

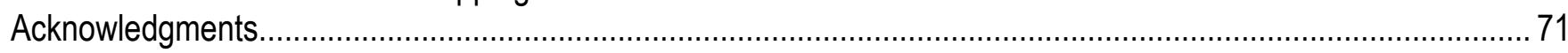

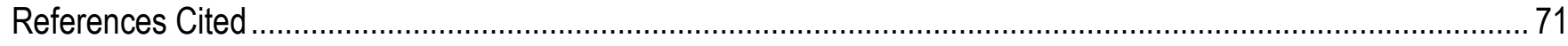

Appendix A. Metadata for Landsat Scenes Used in Regionwide Mapping and Habitat Time Series .......................75

Appendix B. Normalized Difference Vegetation Index (NDVI) Conversions for Landsat 8 ...................................... 83

\section{Figures}

Figure 1. Maps showing location of the project area and the 35 U.S. Fish and Wildlife Service Southwestern Willow Flycatcher management unit boundaries, designated critical-habitat reaches, and waterbodies considered by the satellite model for regionwide modeling, Southwestern United States. 
Figure 2. Map showing yearly distribution of tamarisk beetles (Diorhabda spp.) throughout

Western United States, 2007-14. (Map produced by the Tamarisk Coalition.)

Figure 3. Map showing paths and rows of 57 Landsat scenes overlapping breeding range of

Southwestern Willow Flycatcher, Southwestern United States.

Figure 4. Map showing all fourth-order or larger streams and waterbodies, plus lakes greater than 1 square

kilometer, and two elevation zones (1) below 1,524 m, and (2) above 1,524 m.

Figure 5. Map showing urban and agriculture areas identified and masked (that is, excluded) from the satellite model.

Figure 6. Maps showing effects of masking on output from satellite model at confluence of the Colorado and Gila Rivers, Arizona and California .......

Figure 7. Map showing locations of 758 Southwestern Willow Flycatcher (SWFL) territories that were used for model verification overlaid on 35 U.S. Fish and Wildlife Service management unit boundaries, Southwestern United States, summer 2014

Figure 8. Map showing boundary (polygon with seven segments) of lower Virgin River where a

habitat time series was calculated and a change detection was done, Nevada and Arizona, 1986-2015

Figure 9. Map showing Lower Colorado River boundary, tamarisk patches and structure (I-VI), U.S. Fish and Wildlife Service (FWS) Southwestern Willow Flycatcher (SWFL) management unit boundaries overlaid on a normalized difference vegetation index (NDVI) image obtained July 2015, California, Nevada, and Arizona.

Figure 10. Map showing project boundary, nine river reaches used in tamarisk leaf beetle-impact simulation, and nine vegetation classes, upper Gila River, Arizona, 1986-2015.

Figure 11. Graph showing area of predicted flycatcher breeding habitat below 1,524-meter elevation and for all elevations by State. Number above each bar is area of predicted habitat in square kilometers.................. 22 Figure 12. Graphs showing area of predicted flycatcher breeding habitat in U.S. Fish and Wildlife Service management units below and above 1,524-meter elevation, Southwestern United States, 2013-15.................... 24

Figure 13. Graph showing changes in predicted flycatcher breeding habitat in U.S. Fish and Wildlife Service management units below and above 1,524-meter elevation and for all elevations, 2013-15

Figure 14. Map showing area of predicted flycatcher breeding habitat (averaged across 2013-15) at

all elevations in 6,521 U.S. Geological Survey 7.5-minute quadrangles, Southwestern United States.

Figure 15. Graph showing changes in predicted flycatcher habitat for the 50 top-ranked

U.S. Geological Survey 7.5-minute quadrangles below 1,524-meter elevation, 2014-15.

Figure 16. Maps showing predicted flycatcher breeding habitat at $(A)$ Paraje Well and San Marcial, New Mexico, June 2013, and (B) San Carlos Reservoir, south-central Arizona .

Figure 17. Graph showing density of flycatcher territories $(n=747)$ in 2014 in five probability

classes output by the satellite model.

Figure 18. Flycatcher habitat suitability maps of the upper Owens River, California........................................... 37

Figure 19. Flycatcher habitat suitability maps of Alamo Lake, Arizona

Figure 20. Flycatcher habitat suitability maps of Rio Grande (Elephant Butte Reservoir), New Mexico....

Figure 21. Fflycatcher habitat suitability maps of Havasu National Wildlife Refuge (Topock Marsh), Arizona and California.

Figure 22. Flycatcher habitat suitability maps of the Santa Margarita and San Luis Rey Rivers

(Camp Pendleton), California.

Figure 23. Map showing relative changes in predicted flycatcher habitat, as determined from a satellite model at a 40-percent probability threshold, Southwestern United States, 2013-15.

Figure 24. Map showing changes in predicted flycatcher habitat at Lake McMillan, Texas,

June 2014-June 2015

Figure 25. Map showing changes in predicted flycatcher habitat in Fort Craig and San Marcial quadrangles, New Mexico, 2014-15. 
Figure 26. A habitat time series of the lower Virgin River (see fig. 8), Nevada and Arizona, produced by running the satellite model repeatedly from 1986 to 2015 (2012 omitted)

Figure 27. Map showing changes in predicted flycatcher habitat along the lower Virgin River, Nevada and Arizona, 2010-2015, as determined from a satellite model at a 40-percent probability threshold.

Figure 28. Graph showing changes in area of predicted flycatcher habitat in the lower Virgin River, Nevada and Arizona (fig. 27), 2010-2015.

Figure 29. Graph showing changes in NDVI values in four zones from 2010 (June 22) to 2015 (June 25-) in the lower Virgin River, Nevada and Arizona.

Figure 30. Graph showing changes in predicted flycatcher habitat inside seven zones (fig. 27) along the lower Virgin River, Nevada and Arizona, 2010-2015

Figure 31. Graph showing simulation results showing how tamarisk leaf beetles may affect flycatcher habitat at northern part (Topock Marsh) of Havasu National Wildlife Refuge along lower Colorado River, Arizona and California

Figure 32. Map showing simulation results showing how tamarisk leaf beetles may affect flycatcher habitat at Cibola National Wildlife Refuge along lower Colorado River, Arizona and California 59

Figure 33. Graph showing three states of flycatcher habitat related to tamarisk leaf beetle-impact simulation along lower Colorado River, Arizona and California

Figure 34. Graph showing changes in predicted flycatcher habitat along the lower Colorado River, by U.S. Fish and Wildlife Service management units(see fig. 9), after simulating a tamarisk leaf beetle infestation, Arizona and California

Figure 35. A habitat time series of predicted flycatcher habitat for upper Gila River, Arizona, from 1986 to 2015 , plus the area of predicted flycatcher habitat after simulating a tamarisk leaf beetle infestation in $2015(2015 b)$

Figure 36. Map showing changes in predicted flycatcher habitat along the upper Gila River after conducting a tamarisk leaf beetle-impact simulation

Figure 37. Graph showing three states of flycatcher habitat produced by a tamarisk leaf beetle-impact simulation along the upper Gila River.

Figure 38. Graph showing simulated changes (percent) in predicted flycatcher habitat within 9 zones along the upper Gila River

Figure 39. Drought maps portray a drought that intensifies to the west and decreases in the eastern portion of the study area from 2013 to 2015 (U.S. Department of Agriculture, 2015).

\section{Tables}

Table 1. Changes in predicted flycatcher habitat in U.S. Fish and Wildlife Service management units,

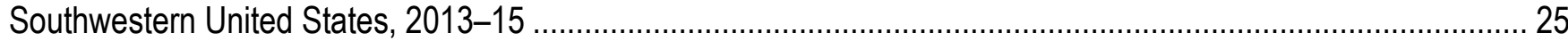

Table 2. Top-ranked 50 7.5-minute U.S. Geological Survey quadrangles by average area (hectares) of predicted flycatcher habitat, Southwestern United States, 2013-15.

Table 3. Predicted flycatcher habitat in 87 U.S. Fish and Wildlife Service critical-habitat reaches (Unit name), located within 6 recovery units and 35 management units, Southwestern United States, 2013-15

Table 4. Area of predicted flycatcher habitat before and after tamarisk leaf beetle-impact analysis was done for the lower Virgin River, Nevada and Arizona, 2010 and 2015

Table 5. Changes in predicted Southwestern Willow Flycatcher habitat along lower Colorado River, California, Nevada, and Arizona, after a beetle-impact simulation was done in 2015.

Table 6. Area of predicted flycatcher habitat before and after a tamarisk leaf beetle-impact simulation was done for the upper Gila River, Arizona. 


\section{Conversion Factors}

Inch/Pound to International System of Units

\begin{tabular}{|c|c|c|}
\hline Multiply & By & To obtain \\
\hline \multicolumn{3}{|c|}{ Area } \\
\hline acre & 0.4047 & hectare (ha) \\
\hline acre & 0.4047 & square hectometer $\left(\mathrm{hm}^{2}\right)$ \\
\hline acre & 0.004047 & square kilometer $\left(\mathrm{km}^{2}\right)$ \\
\hline \multicolumn{3}{|c|}{ International System of Units to Inch/Pound } \\
\hline Multiply & By & To obtain \\
\hline \multicolumn{3}{|c|}{ Length } \\
\hline meter $(\mathrm{m})$ & 3.281 & foot $(\mathrm{ft})$ \\
\hline kilometer (km) & 0.6214 & mile (mi) \\
\hline \multicolumn{3}{|c|}{ Area } \\
\hline square meter $\left(\mathrm{m}^{2}\right)$ & 0.0002471 & acre \\
\hline square meter $\left(\mathrm{m}^{2}\right)$ & 10.76 & square foot $\left(\mathrm{ft}^{2}\right)$ \\
\hline hectare (ha) & 2.471 & acre \\
\hline hectare (ha) & 0.003861 & square mile $\left(\mathrm{mi}^{2}\right)$ \\
\hline square hectometer $\left(\mathrm{hm}^{2}\right)$ & 2.471 & acre \\
\hline square kilometer $\left(\mathrm{km}^{2}\right)$ & 247.1 & acre \\
\hline square kilometer $\left(\mathrm{km}^{2}\right)$ & 0.3861 & square mile $\left(\mathrm{mi}^{2}\right)$ \\
\hline
\end{tabular}

\section{Datums}

Vertical coordinate information is referenced to the North American Vertical Datum of 1988 (NAVD 88).

Horizontal coordinate information is referenced to the North American Datum of 1983 (NAD 83).

Elevation, as used in this report, refers to distance above the vertical datum.

\section{Abbreviations}

$\mathrm{Cl} \quad$ confidence interval

FWS U.S. Fish and Wildlife Service

GAP Gap Analysis Program

GIS geographic information system

NDVI normalized difference vegetation index

Reclamation Bureau of Reclamation

TOA top-of-atmosphere 


\title{
A Satellite Model of Southwestern Willow Flycatcher (Empidonax traillii extimus) Breeding Habitat and a Simulation of Potential Effects of Tamarisk Leaf Beetles (Diorhabda spp.), Southwestern United States
}

\author{
By James R. Hatten
}

\section{Executive Summary}

The study described in this report represents the first time that a satellite model has been used to identify potential Southwestern Willow Flycatcher (Empidonax traillii extimus) (hereinafter referred to as "flycatcher") breeding habitat rangewide for 2013-15. Fifty-seven Landsat scenes were required to map the entire range of the flycatcher, encompassing parts of six States and more than 1 billion 30meter pixels. Predicted flycatcher habitat was summarized in a hierarchical fashion from largest to smallest: regionwide, State, U.S. Fish and Wildlife Service (FWS) management unit, 7.5-minute quadrangle, and critical-habitat reach. The term "predicted habitat" is used throughout this report to distinguish areas the satellite model predicts as suitable flycatcher habitat from what may actually exist on the ground. A rangewide accuracy assessment was done with 758 territories collected in 2014, and change detection was done with yearly habitat maps to identify how and where habitat changed over time. Additionally, effects of tamarisk leaf beetles (Diorhabda spp.) on flycatcher habitat were summarized for the lower Virgin River from 2010 to 2015, and simulations of how tamarisk leaf beetles may affect flycatcher habitat in the lower Colorado and upper Gila Rivers were done for 2015. Model results indicated that the largest areas of predicted flycatcher habitat at elevations below 1,524 meters were in New Mexico and Arizona, areas followed in descending order by California, Texas, Nevada, Utah, and Colorado. By FWS management unit, the largest area of flycatcher habitat during all 3 years were the Middle Rio Grande (New Mexico), followed by the Upper Gila (Arizona and New Mexico) and Middle Gila/San Pedro (Arizona) management units. The area of predicted flycatcher habitat varied considerably in 7.5-minute quadrangles, ranging from 0 to1,398 hectares (ha). Averaged across 3 years, the top three producing quadrangles were Paraje Well (New Mexico), San Marcial (New Mexico), and San Carlos Reservoir (Arizona). The top three FWS critical-habitat reaches in 2015 were Rio Grandemiddle (9,544 ha), San Pedro River (1,779 ha), and Gila River-mid San Carlos (1,356 ha); this ranking did not change in 2013 or 2014. Change detection among years showed a large shift in predicted flycatcher habitat influenced by drought patterns, with California habitat decreasing and New Mexico habitat increasing. An accuracy assessment indicated that 88 percent of territories were correctly classified at a 40 percent probability threshold, with an exponential relationship between territory densities and five probability classes. A spatially explicit analysis indicated that beetles decreased predicted flycatcher habitat 94.2 percent from 2010 to 2015 along the lower Virgin River, with only 5.8 percent persisting. In contrast, beetle simulations indicated that 64.1 percent of habitat will persist along the lower Colorado River and 45 percent will persist along the upper Gila River. This project shows that the satellite model adequately predicts flycatcher habitat rangewide, but it lacks the ability to predict 
which patches will be occupied in a given year. The next logical step is the development of an occupancy model that ties the habitat predictions of the satellite model to patch occupancy so managers can better allocate their resources for survey and restoration activities. Finally, the methods presented in this report seem well suited for automated mapping applications and cloud-based resources.

\section{Introduction}

The Southwestern Willow Flycatcher (Empidonax traillii extimus, hereinafter referred to as "flycatcher") is a federally endangered species that occurs patchily along rivers and streams in the Southwestern United States during May-September (U.S. Fish and Wildlife Service, 1995, 2002). The flycatcher breeding habitat is characterized by a mosaic of relatively dense tree and shrub growth, typically in association with surface water or saturated soil, interspersed with more open areas, open water, or shorter, sparser vegetation along rivers, streams, or other wetlands. Plant species composition, vegetation height and density, and patch size vary greatly, but most occupied sites typically consist of dense vegetation in the interior of the patch and within 3-4 m of the ground (Sogge and Marshall, 2000; U.S. Fish and Wildlife Service, 2002; Sogge and others, 2010). Because habitat loss and degradation are the main factors contributing to the decline of the species, the flycatcher recovery plan emphasizes the increase and improvement of breeding habitat through restoration of native breeding habitat and the management of exotic vegetation (U.S. Fish and Wildlife Service, 2002). The estimated rangewide breeding population of flycatchers as of the last compilation in 2007 was roughly 1,299 territories distributed among 288 known sites (Durst and others, 2008).

In 2013, the U.S. Fish and Wildlife Service (FWS) designated revised critical habitat for the flycatcher under the Endangered Species Act (U.S. Fish and Wildlife Service, 2013). A total of about 1,975 stream kilometers were designated as critical habitat, located in 6 states, 38 counties, 24 management units, and 6 recovery units. Identified by stream segment, the lateral extent includes riparian areas and streams in the 100-year floodplain, encompassing about 84,569 ha (fig. 1). The FWS would like to acquire the ability to locate, map, and monitor potential flycatcher breeding habitat rangewide, including areas not designated as critical habitat. Most flycatcher habitat is inherently dynamic, with individual riparian patches subject to cycles of creation, growth, and loss because of drought, flooding, fire, and other disturbances. Former breeding patches can lose suitability quickly, whereas new habitat can develop in a few years, especially in reservoir drawdown zones (Paradzick and Hatten, 2004; Paxton and others, 2007). Because the distribution and extent of flycatcher habitat changes over time, an accurate understanding and assessment of current habitat suitability requires upto-date information on vegetation characteristics and other variables associated with occupied sites. 


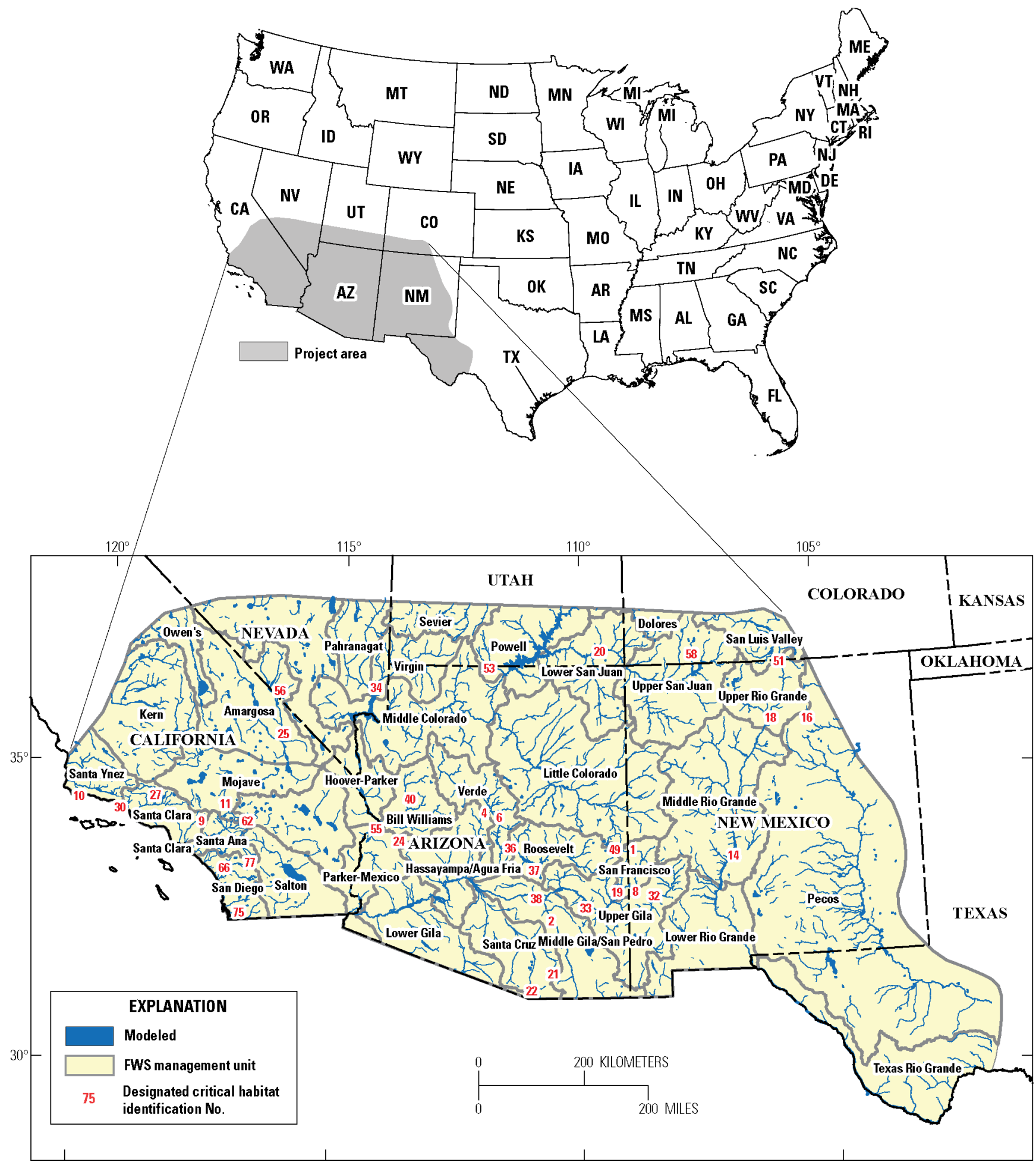

Figure 1. Maps showing location of the project area and the 35 U.S. Fish and Wildlife Service Southwestern Willow Flycatcher management unit boundaries, designated critical-habitat reaches, and waterbodies considered by the satellite model for regionwide modeling, Southwestern United States. 
The Arizona Game and Fish Department developed a flycatcher remote sensing/geographic information system (GIS) habitat model (hereinafter referred to as the "satellite model") that uses Landsat Thematic Mapper imagery and a 30-m-resolution digital elevation model (Hatten and Paradzick, 2003). The satellite model was developed with presence/absence survey data acquired along the San Pedro and Gila Rivers, and from Salt River and Tonto Creek inlets to Roosevelt Lake in southern Arizona. The satellite model uses a logistic regression equation to divide riparian vegetation into a continuous range of probabilities extending from almost 0 to 99 percent, with higher probabilities most likely to contain a flycatcher territory. The model has been successfully tested at Alamo Lake, Arizona (Hatten and Paradzick, 2003); applied statewide in Arizona with 2001 imagery (Dockens and others, 2004); and projected along the Rio Grande River, New Mexico (Hatten and Sogge, 2007). In each case, the satellite model performed within expectations by identifying riparian areas with the highest densities of flycatcher territories. In a follow-up study, the satellite model explained 79 percent of the fluctuation in the flycatcher breeding population at Roosevelt Lake from 1996 to 2005 (Paxton and others, 2007; Hatten and others, 2010).

A secondary objective of this project was to identify how and where the recently introduced tamarisk leaf beetle (Diorhabda spp.) is affecting flycatcher habitat in the Southwestern United States. In 2001, tamarisk leaf beetles (hereinafter referred to as "beetle") were released by the U.S. Department of Agriculture Animal and Plant Health Inspection Service at 10 sites in six States (California, Nevada, Utah, Colorado, Wyoming, and Texas) to control invasive tamarisk (Tamarix spp.) (Bean and others, 2013). Tamarisk, which is an introduced phreatophyte and a common nesting substrate for flycatchers and other birds (Sogge and others, 2008; Paxton and others, 2011), spread rapidly following its release over a century ago and is now a dominant riparian species throughout the West (Chew, 2013). Feeding by the beetle larvae defoliates the tamarisk during the growing season and reduces plant vigor, sometimes resulting in plant mortality within 5 years (Hultine and others, 2009, 2015). Since their introduction, beetles have spread naturally into most drainages of the upper Colorado River Basin (Jamison and others, 2015), southern Utah and Nevada, and the main stem lower Colorado River in Arizona (fig. 2). 


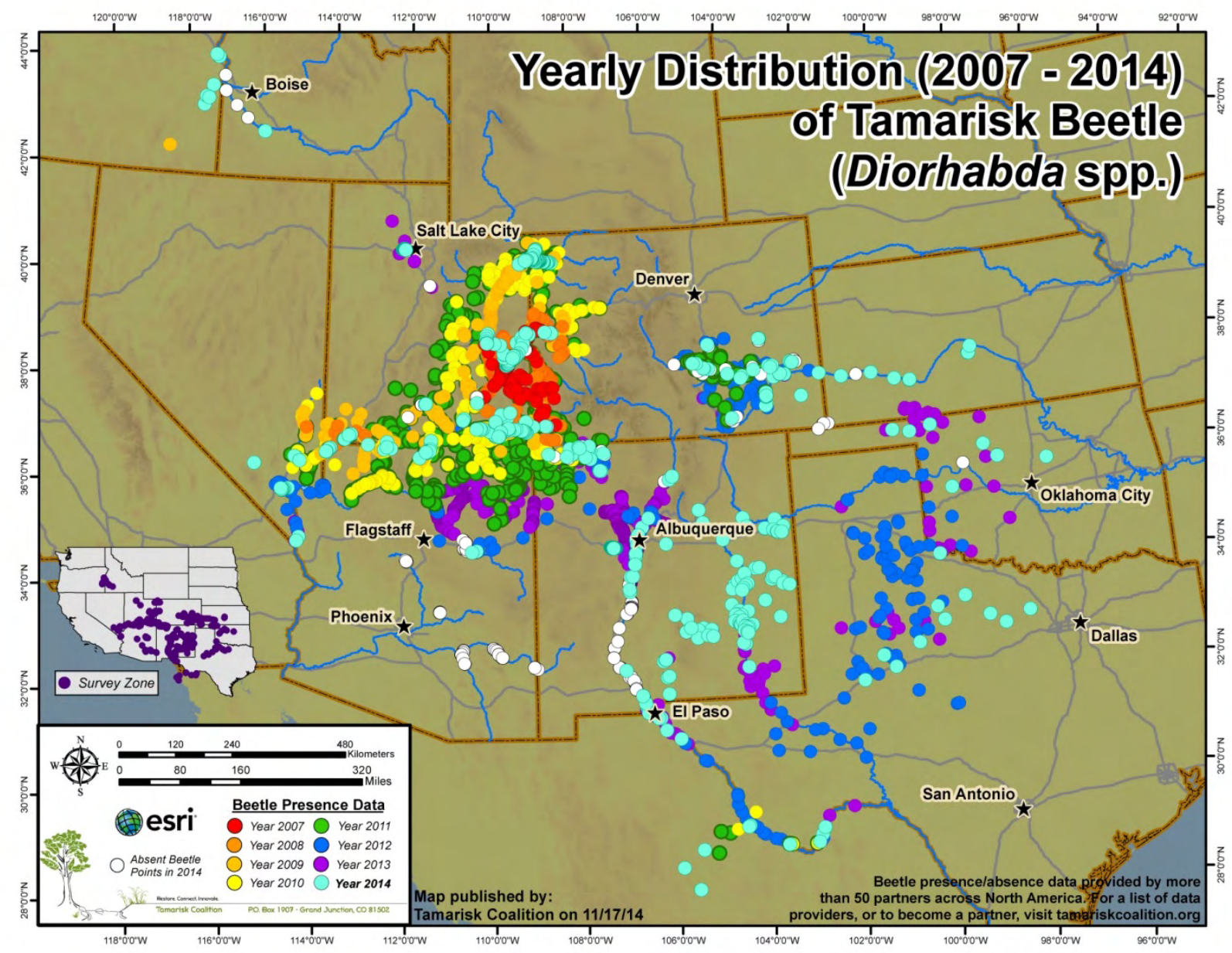

Figure 2. Map showing yearly distribution of tamarisk beetles (Diorhabda spp.) throughout Western United States, 2007-14. (Map produced by the Tamarisk Coalition.)

The northern tamarisk leaf beetle (D. carinulata) has colonized sites in the northern part of the Rio Grande and the subtropical tamarisk beetle (D. sublineata) is spreading from western Texas, colonizing the southern part of the Rio Grande from Hatch, New Mexico, south to the Mexico border (Johnson and Jamison, 2015). The beetle species originating from western Texas are known to have additional generations (4-5 generations), leading to an increase in distribution and defoliation as population growth expands throughout the Rio Grande corridor. The beetle is expected to be prevalent throughout the Lower Colorado, Rio Grande, and Gila River systems within the next 2-3 years ( J. Tracy, Texas A\&M University, written commun., April 2016), where tamarisk is widely used for breeding by flycatchers and other riparian birds. The pace and extent of beetle expansion may cause widespread damage to flycatcher breeding habitat over the coming decades (Paxton and others, 2011; Bean and others, 2013; Sogge and others, 2013), as it already has caused along the lower Virgin River (Bateman and others, 2013; Nagler and others, 2014). The ability to simulate potential effects of beetles on flycatcher habitat years in advance would provide managers with a head start in restoring and enhancing river reaches before their arrival, thereby minimizing damage to critical flycatcher habitat. 
In the face of so much dynamism, the only effective way to locate, map, and monitor flycatcher habitat rangewide is with a combination of remote sensing, field surveys, and GIS technology (U.S. Fish and Wildlife Service, 2002; Hatten and others, 2010). The satellite model has broad application for identifying and classifying flycatcher breeding habitat rangewide. However, details of flycatcher habitat characteristics can vary in different parts of the range, especially between low- and high-elevation sites. Additionally, the distinctness of riparian patches and adjacent natural and human-influenced habitat differs across the range. Therefore, applying the satellite model rangewide requires significant development of a geospatial database, testing and refinement of techniques used to automate the application and processing of satellite imagery, and model verification in different parts of flycatcher range. This project had three distinct objectives:

1. To identify, map, and monitor flycatcher breeding habitat rangewide with a published satellite model (Hatten and Paradzick, 2003);

2. To identify, quantify, and monitor beetle damage to flycatcher breeding habitat with the satellite model; and

3. To develop a methodology to simulate beetle impacts to flycatcher habitat so managers can identify potential restoration and enhancement strategies in advance.

\section{Methods}

\section{Satellite-Based Habitat Predictions}

\section{Geospatial Database}

The satellite model requires 57 Landsat scenes in order to map "predicted flycatcher breeding habitat" rangewide (fig. 3), comprising about 1.1 billion $900-\mathrm{m}^{2}$ pixels $\left(1,002,839 \mathrm{~km}^{2}\right)$. The word "predicted" is used throughout this report to distinguish areas the satellite model predicts as suitable flycatcher habitat from what areas may actually exist on the ground. Additionally, 30 Landsat scenes were used (1986-2015) when producing habitat time series at numerous locations. Producing a rangewide map and developing habitat time series required careful attention to image preparation and numerical adjustments because of differences in Landsat sensors and acquisition dates (Hatten and others, 2010; Hatten, 2014), which was accomplished in several steps. First, differences in predicted habitat owing to seasonal effects were minimized by selecting images that were acquired as close to June 21 as possible. It was not possible to select the same date each year because clouds sometimes obscured the view, or image quality sometimes varied because of satellite malfunctions. In such circumstances, the next available Landsat scene was selected, which was 16 days prior to or after the target date, because Landsat reimages the Earth every 16 days. Each image was previewed before selection with the U.S. Geological Survey GLOVIS tool (U.S. Geological Survey, 2005). The same sensor (Landsat 5 Thematic Mapper) was operational from 1986 to 2011, so those scenes were entered directly into the satellite model without applying any adjustments to the imagery (see appendix A (A1-A3) for Landsat imagery metadata related to rangewide modeling from 2013 to 2015). 
When using Landsat 8 imagery, adjustments were made for a numerical scaling issue (Landsat 5 is 8 bit and Landsat 8 is 16 bit) and for differences in normalized difference vegetation index (NDVI) values because of slight differences in the red and reflected infrared bands. Specifically, Landsat 8 scenes were adjusted (years 2013-15) to top-of-atmosphere (TOA) reflectance to correct the numerical scaling issue between the two sensors (Chander and others, 2009). Landsat 8 NDVI values then were adjusted with a two-step linear regression so they matched Landsat 5 values; without these two adjustments, the satellite model will not work correctly with Landsat 8 imagery (see Chander and others, 2009, for TOA corrections and appendix B for details about the two-step regression for NDVI).

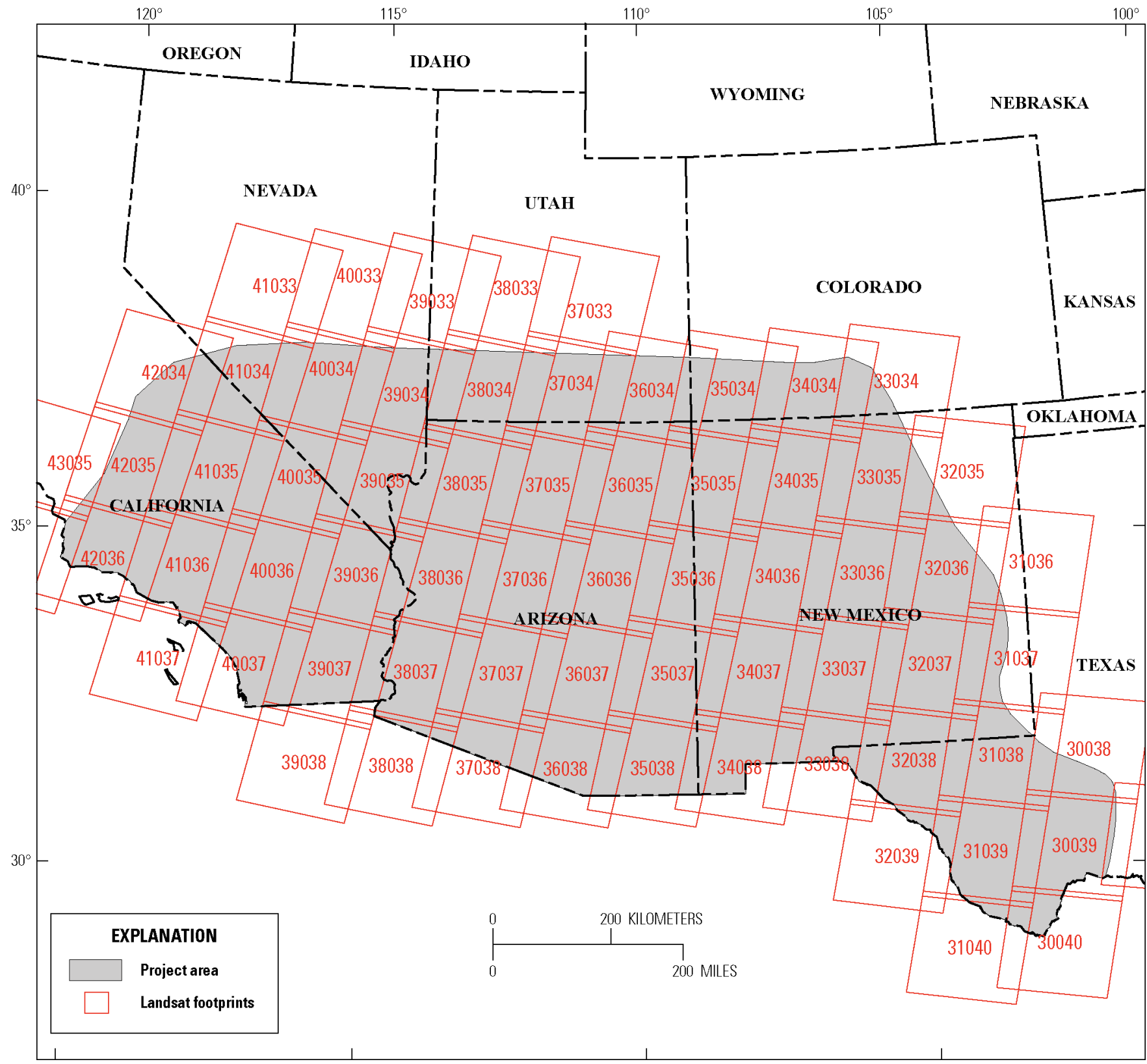

Figure 3. Map showing paths and rows of 57 Landsat scenes overlapping breeding range of Southwestern Willow Flycatcher, Southwestern United States. 
The scale of the modeling required development of new techniques to identify potential flycatcher habitat and to create the most specific and accurate maps possible.

1. Riparian areas where flycatcher territories may occur were identified by buffering streams, rivers, and waterbodies according to their size,

2. All urban and agricultural areas were masked (excluded) because flycatchers do not breed in such areas,

3. Anthropogenic features (for example, circles, rectangles, lines) were identified and masked on Landsat scenes that were missed with the distance-to-water mask, and

4. All potentially suitable areas above or below 1,524-m elevation were identified and attributed because this is an important elevation boundary (Hatten and Paradzick, 2003).

A variable-width buffer was created for modeling purposes in several steps. First, the river/stream reaches and waterbodies nearest the 288 known flycatcher sites were identified by overlaying flycatcher sites and the NHDPlus2 stream network (McKay and others, 2012). This exploratory analysis indicated that most flycatcher sites were adjacent to stream or river reaches greater than third order (fourth to ninth order) and lakes greater than $1 \mathrm{~km}^{2}$. Second, given that larger-order streams or rivers have larger floodplains, and thus more riparian area that may contain a flycatcher territory, a variable-width buffer was created for modeling. Specifically, the order of the stream or river was multiplied by $100 \mathrm{~m}$, and waterbodies larger than $1 \mathrm{~km}^{2}$ were buffered by $1 \mathrm{~km}$. Thus, for modeling purposes, buffers were $400 \mathrm{~m}$ for fourth-order streams , $900 \mathrm{~m}$ for ninth-order rivers, and $1 \mathrm{~km}$ for waterbodies greater than $1 \mathrm{~km}^{2}$. Third, all areas outside of buffer zones were masked so they would not be considered by the satellite model. These variable-width buffers adjacent to streams, rivers, and waterbodies represent the initial areas considered for modeling (fig. 4), comprising about 6 percent of the project area $\left(59,887 \mathrm{~km}^{2}\right)$.

Pinyon pine (Pinus edulis) and juniper (Juniperus spp.) were masked inside riparian buffer zones with high-resolution imagery because the satellite model commonly confuses them with riparian vegetation above 1,524-m elevation (Hatten and Sogge, 2007). Spectral confusion between pines and riparian vegetation usually is not a problem below 1,524-m elevation (Hatten and Paradzick, 2003), but for this project, all elevations were considered in order to include a small number of flycatcher sites in Colorado (Durst and others, 2008). Because high-elevation flycatcher habitat is problematic and results in more classification errors, the area of predicted flycatcher habitat was tracked above and below the 1,524-m elevation boundary throughout the rangewide analysis, by management unit (fig. 4).

All urban and agricultural areas within proximity-to-water buffers were masked because flycatcher territories do not occur in such areas (fig. 5). This processing operation involved several steps to accomplish. First, all urban and agricultural features identified in the Southwest and South-Central U.S. Geological Survey Gap Analysis Program (GAP) layers (Lowry and others, 2005) were extracted and masked. Second, the urban and agricultural mask was updated by digitizing omitted areas that were clearly visible on high-resolution digital aerial photographs. Omitted areas typically were agricultural fields that had increased in size in the last decade, or urban boundaries. Third, areas that were incorrectly classified as urban or agricultural were identified and the mask in such areas was removed, thereby including them in the modeling arena. 


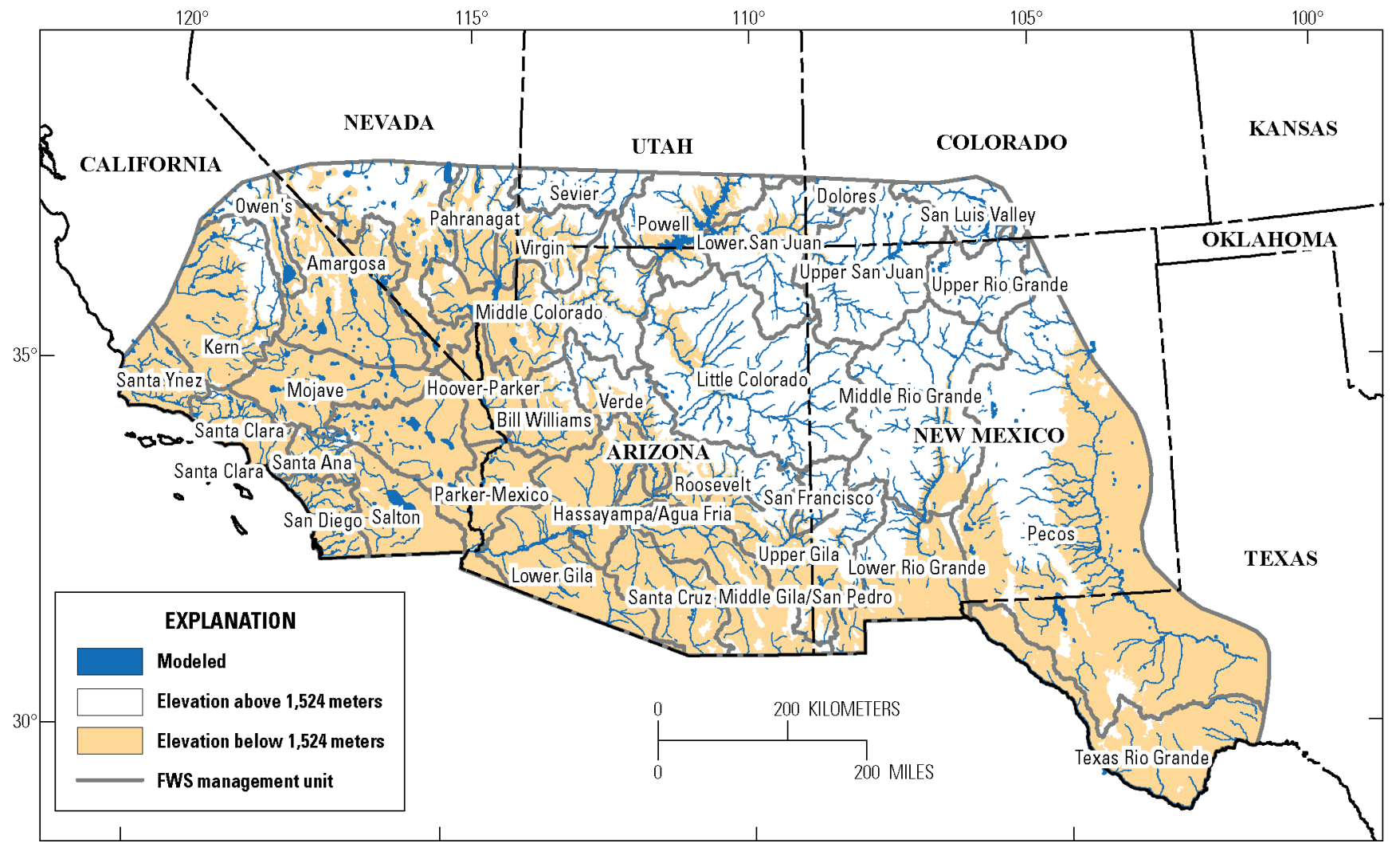

Figure 4. Map showing all fourth-order or larger streams and waterbodies, plus lakes greater than 1 square kilometer, and two elevation zones (1) below 1,524 m, and (2) above 1,524 m.

The final masking step was an ocular assessment, whereby areas that were not organic in shape (for example, circles, lines, squares) were visually identified with the aid of high-resolution aerial orthophotographs and GIS, and excluded (fig. 6). This was primarily a refinement of the GAP layer because agricultural areas oftentimes become spectrally confused with riparian areas along their interface. Although such areas were difficult to discern with 30-m resolution Landsat imagery, they were visible with 1-m resolution aerial photography, making their identification and digitization possible. Additionally, I excluded from the masks numerous agricultural fields that the Bureau of Reclamation (Reclamation) converted from agricultural plantations to native vegetation in hopes of providing flycatcher habitat; such areas retained a non-organic shape and were initially masked. Finally, all urban footprints that had enlarged since the last GAP assessment were identified and masked because they were not classified as urban at that time; such adjustments were necessary because flycatchers do not breed in urbanized areas. 


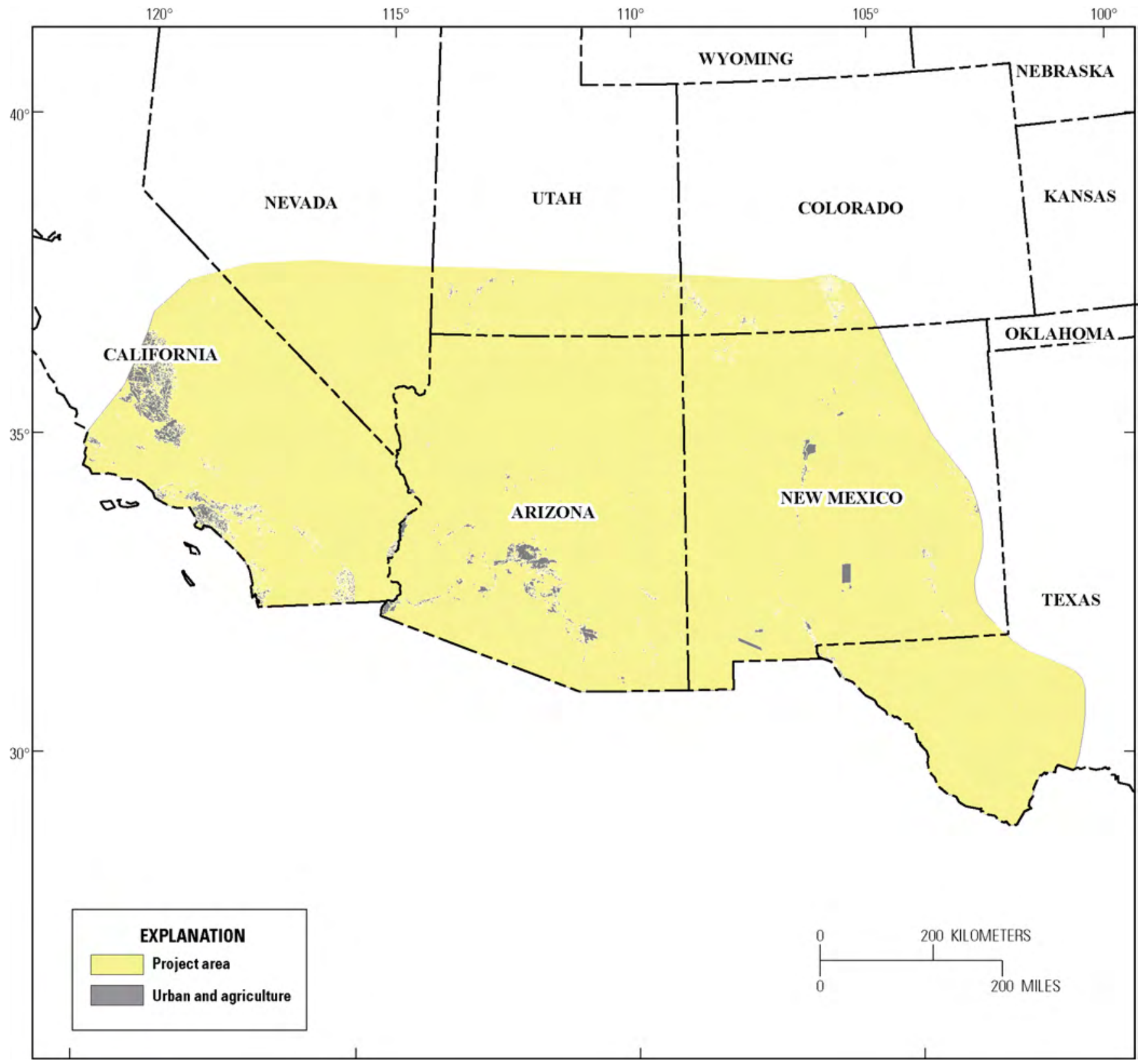

Figure 5. Map showing urban and agriculture areas identified and masked (that is, excluded) from the satellite model. 

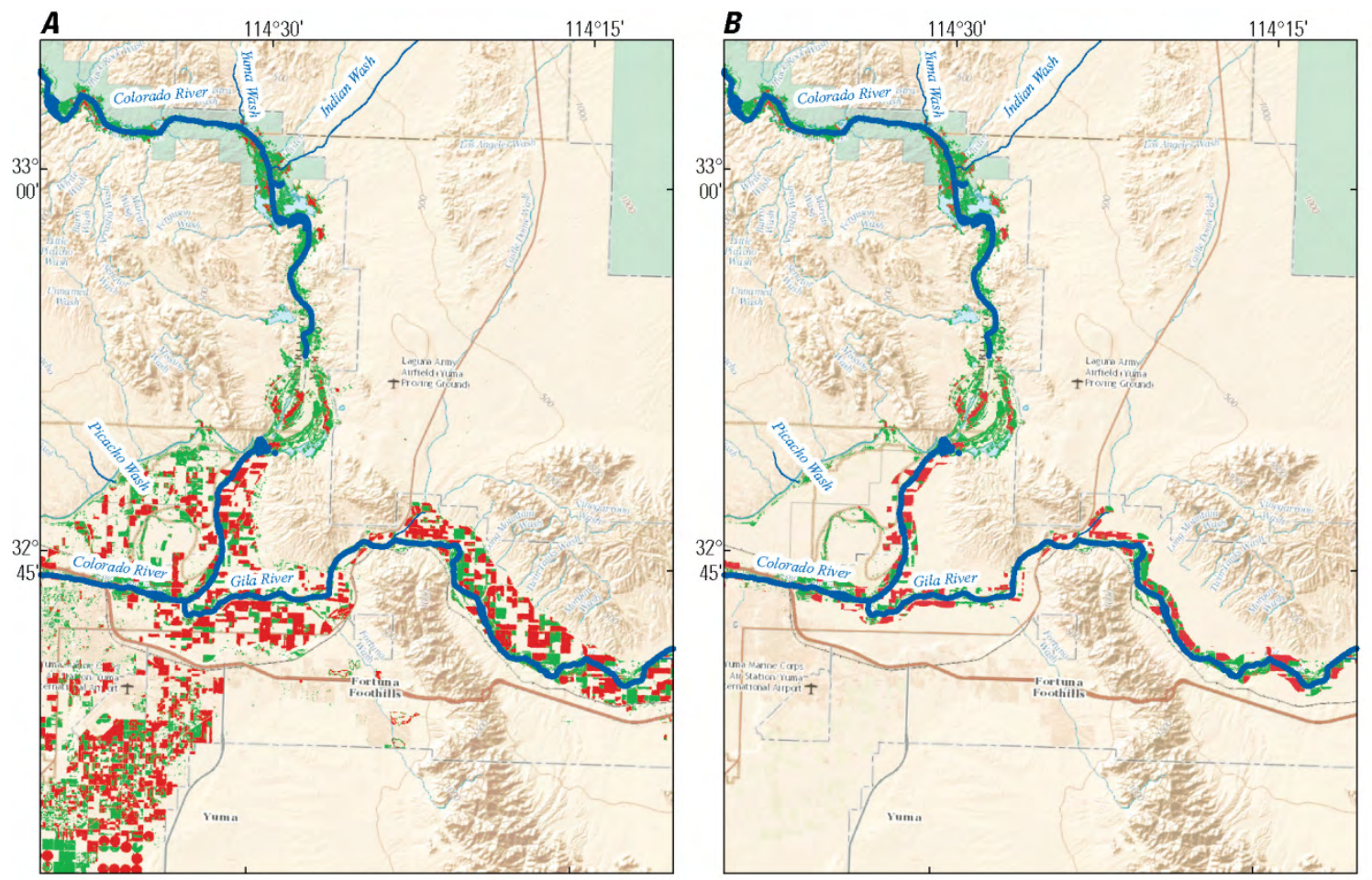

EXPLANATION
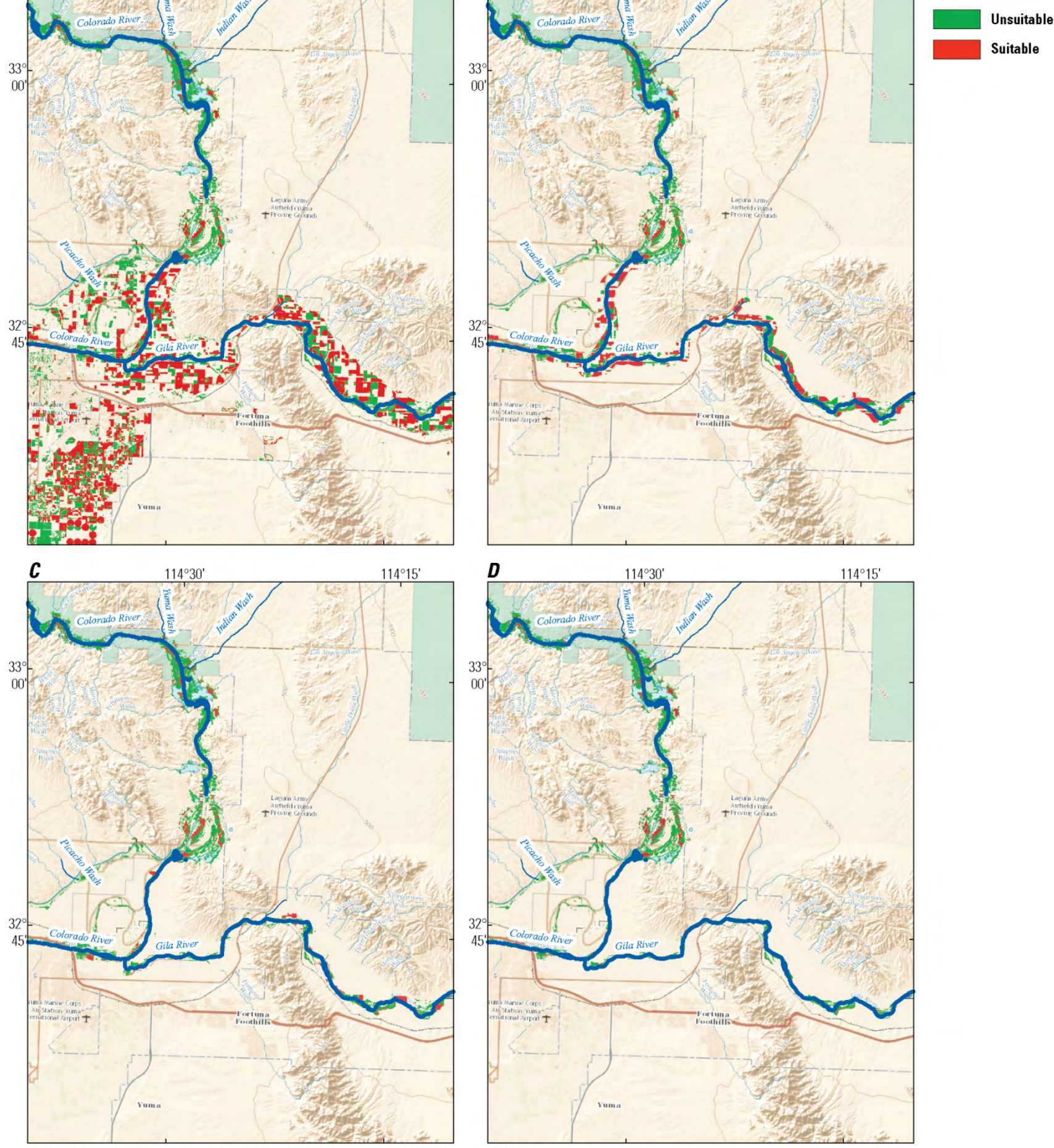

Base map from USGS The National Map: National Boundaries Dataset National Elevation Dataset Geographic Names Information System, National Hydrography Dataset, National Land Cover Database, National Structures Dataset, and National Transportation Dataset;

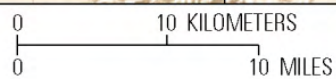

U.S. Census Bureau - TIGER/Line; HERE Road Data

Figure 6. Maps showing effects of masking on output from satellite model at confluence of the Colorado and Gila Rivers, Arizona and California. (A) No mask applied. (B) Distance-to-water mask applied. (C) Urban-agriculture mask applied. (D) Ocular mask applied. In these maps, the masks are additive from $B$ to $D$. 


\section{Application of the Satellite Model}

Four steps were completed to project and test the satellite model rangewide (Hatten and Paradzick, 2003):

1. Four GIS variables derived from Landsat Thematic Mapper (TM) imagery and 30-m resolution digital elevation models (DEMs) were created;

2. A logistical regression model was populated with four GIS variables and a probability grid was created;

3. Riparian vegetation was divided into probability classes;

4. Model accuracy (sensitivity and specificity) was assessed within five probability classes and at a 40-percent probability threshold, with flycatcher territory locations collected throughout flycatcher range.

The satellite model uses a logistical regression equation developed by Hatten and Paradzick (2003) to calculate the probability of flycatcher habitat with the following equation:

$$
\text { Habitat probability }=\exp ^{(\text {logit })} / 1+\exp ^{(\text {logit })}
$$

where

logit is $1.483($ NDVI) +0.098 (NDVIBEST) +0.034 (FLOODPL) +0.648 (NDVISTD) -6.074 , whereby the four variables are defined as follows:

1. $\mathrm{NDVI}=$ dense vegetation $(\mathrm{NDVI}>0.33)$ within a $30 \times 30-\mathrm{m}$ cell $(0.09 \mathrm{ha})$;

2. NDVIBEST $=$ amount (percent) of densest vegetation (NDVI $>0.41$ ) within a $120-\mathrm{m}$ radius (4.5-ha neighborhood);

3. FLOODPL = amount (percent) of floodplain or flat terrain $(<2.5$ degrees $)$ within a $360-\mathrm{m}$ radius (41-ha neighborhood);

4. NDVISTD $=$ the standard deviation in NDVI (12 classes) within a $120-\mathrm{m}$ radius (4.5-ha neighborhood).

The three vegetation variables are extracted from Landsat TM imagery, and the FLOODPLAIN variable is extracted from a 30-meter resolution DEM.

A set of custom GIS scripts were used to extract and process the information necessary to populate the satellite model (Hatten and Paradzick, 2003). Given the large size of the project area, each Landsat scene was individually processed. Once completed, all 57 scenes were mosaicked together to form a continuous probability grid for classification and mapping purposes. The immense size of the project area required the division of the floodplain variable into 57 tiles that matched the Landsat footprints. As each Landsat scene was entered into the model, the script supplied the correct floodplain tile to complete the modeling process. Custom scripts also were used to reclassify the continuous probability grids into binary and five-probability-class format. Finally, the individual map tiles were mosaicked together to form a continuous habitat map for the entire range. The probability threshold was set at 40 percent to match the original habitat map (Hatten and Paradzick, 2003), but this threshold can easily be changed should the need arise. For example, if flycatchers occupied areas that were in a higher probability class (for example, 70 percent), increasing the threshold would reduce commission errors because less of the riparian zone would be considered suitable (Paxton and others, 2007). 


\section{Accuracy Assessment}

Habitat maps were created rangewide during 2013-15 and the fit and accuracy of the satellite model were assessed in several ways. Model fit was assessed by overlaying 758 flycatcher territory locations obtained in the summer of 2014 on five probability classes output by the satellite model with 2014 Landsat imagery (fig. 7). The density of flycatcher territories was obtained by dividing territory numbers in each probability class by class area (Hatten and Paradzick, 2003). Past applications of the model have shown that the model is working correctly when flycatcher territory densities increase exponentially in high-probability classes. Model accuracy was assessed by calculating the percentage of flycatcher territories that occurred in predicted habitat at a 40-percent probability threshold because this was the optimum threshold determined in the original model. However, this threshold can be changed whenever model accuracy can be improved without increasing commission errors.

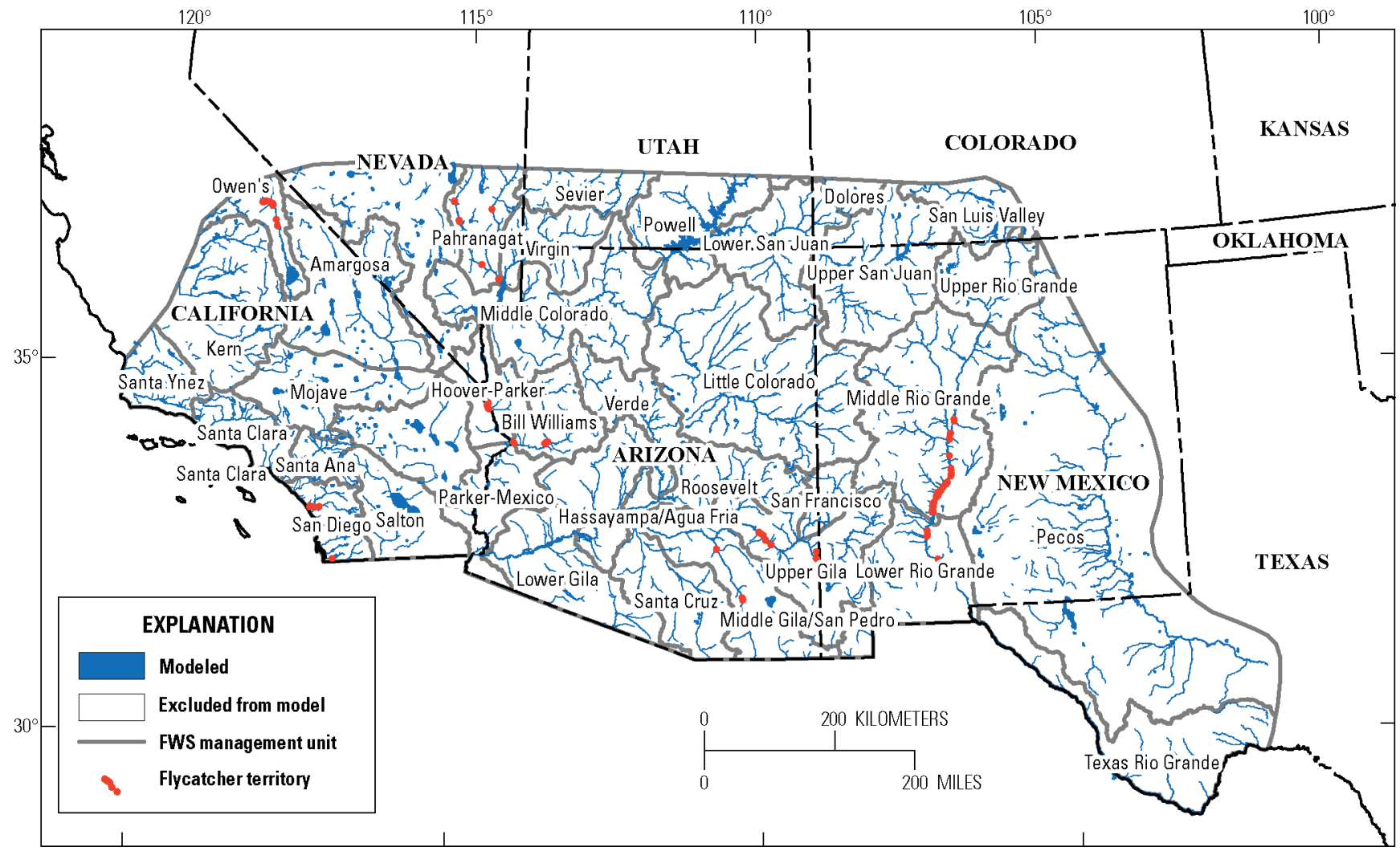

Figure 7. Map showing locations of 758 Southwestern Willow Flycatcher (SWFL) territories that were used for model verification overlaid on 35 U.S. Fish and Wildlife Service management unit boundaries, Southwestern United States, summer 2014. Blue areas are all areas that the satellite model considered when predicting the occurrence of flycatcher habitat; white areas were excluded from modeling. 


\section{Summarization and Display of Model Results}

The broad scale of the project area and the large quantity of data output by the satellite model created challenges when characterizing and displaying information. The minimum mapping unit was an individual Landsat cell ( 0.09 ha), but there were more than 1 billion cells, so these challenges were handled hierarchically. Specifically, the habitat predictions were summarized at five different scales (mesh sizes). At the coarsest scale of analysis, the entire project area was considered irrespective of any internal management units. The remaining four analysis scales, in descending order of resolution, were 6 State boundaries, 35 FWS management units, 88 FWS critical-habitat reaches, and 6,521 7.5-minute quadrangles. These five scales of resolution enabled a thorough analysis and display of predicted flycatcher habitat to satisfy many uses. For example, natural resource managers can review the areas of predicted flycatcher habitat within individual critical-habitat reaches to determine whether additional field visits or analysis are justified, or can determine if additional field surveys should be planned in locations that have seldom or ever been visited based on habitat maps developed from the 7.5-minute quadrangles.

\section{Habitat Change Detection}

After a thorough GIS analysis of predicted flycatcher habitat was done during 2013-15, the results were presented in tabular and (or) graphical format, depending on the variability in the data and sample size. At the regionwide, State, and FWS management-unit scales, the total areas of predicted flycatcher habitat were computed and these results were shown in bar graphs and tables, allowing one to quickly compare which areas increased, decreased, remained the same, or fluctuated. The area of predicted flycatcher habitat that occurred inside 87 critical-habitat reaches was shown in tabular format because the variability in habitat and sample size made a bar graph impractical. In contrast, local and rangewide habitat change-detection maps were created, with results obtained from the 7.5-minutequadrangle analysis, as well as tabular output, because the 1:24,000 scale was a practical scale to work with.

\section{Tamarisk Leaf Beetle Impact Assessment}

Three different modeling scenarios related to beetles and their associated effects on flycatcher habitat were examined.

1. How beetles affected predicted flycatcher habitat along the beetle-infested lower Virgin River (southeast Nevada and northwestern Arizona),

2. How beetles may affect predicted flycatcher habitat along the Lower Colorado River (southern Nevada and western Arizona), and,

3. How beetles may affect predicted flycatcher habitat along the upper Gila River in southeastern Arizona.

The Virgin River analysis differed from the beetle-impact simulations because it provided actual information on how beetles affected flycatcher habitat from 2008 to 2015. The Virgin River case study also provided useful information when interpreting the two beetle-impact simulations done along the lower Colorado and upper Gila Rivers. 
The two locations where beetle impacts on flycatcher habitat were simulated were based on the availability of high-quality vegetation maps that clearly delineated tamarisk patches (Bangle and others, 2014; Neale and others, 2014). Tamarisk maps are necessary to do a beetle-impact simulation because the beetles are tamarisk obligates that feed on the foliage of tamarisk, causing defoliation of the tree. Repeated defoliation of individual tamarisk trees can result in a severe dieback during the next season and ultimately mortality of the tree within several years (Deloach and Carruthers, 2004), affecting potential flycatcher breeding habitat. Beetle effects on predicted flycatcher habitat were simulated along the lower Colorado and upper Gila rivers in several steps. First, the vegetation maps were resampled to match the 30-m pixel resolution of the flycatcher maps (grids) with a 30-m majority filter (that is, the most dominant plant was assigned to a $30-\mathrm{m}$ pixel). The cell centroids were snapped so that the pixels in the plant maps aligned with the flycatcher maps. Second, a conditional statement (CON) was used in $\operatorname{ArcGIS}^{\mathrm{TM}}$ to reduce all Landsat NDVI values at tamarisk locations (cells) by 50 percent (value determined from Virgin River beetle analysis). Third, the flycatcher model was re-run using the altered NDVI values, which affected all three vegetation variables in the satellite model (see eq. 1). Fourth, a comparison was made on a cell-by-cell basis as to how predicted flycatcher habitat changed after the beetle-impact simulation with the ArcGIS ${ }^{\mathrm{TM}}$, COMBINE function. Fifth, changes in predicted habitat were summarized across the entire reach and within distinct zones that had unambiguous start (upstream) and end (downstream) points. When comparing habitat maps created in different years, there were only four possible outcomes (Hatten and Paradzick, 2003):

1. Habitat persisted (remained),

2. Habitat disappeared (lost),

3. Habitat formed (gained), or

4. Unsuitable areas remained unsuitable.

\section{Habitat Time Series}

An important aspect of the beetle analysis was to compare the magnitude of changes in flycatcher habitat to changes caused by natural stressors, such as drought, fire, or floods, as they all affect the quantity and quality of flycatcher habitat annually (Hatten and others, 2010; Orr and others, 2014). Specifically, do beetle impacts on flycatcher habitat exceed the natural annual variability? If so, then by how much? If not, then perhaps the impacts to flycatchers are acceptable and can be considered as just one more natural stressor. Answering these questions required an historical record of flycatcher habitat for a given reach. To do so, two habitat time series were created, one for the lower Virgin River where beetle impacts have actually occurred, and one for the upper Gila River, where beetles have not arrived and impacts were simulated. In the lower Colorado River where beetles have not arrived, beetle effects on flycatcher habitat for 2015 were simulated without the aid of a habitat time series, with reliance instead on the knowledge gained from the Virgin River and upper Gila River habitat time series when interpreting results. 
The two habitat time series were created with Landsat imagery dating from 1986 to 2015, obtained from the EROS satellite archive. Creating a habitat time series involved running the satellite model annually as close to the same date as possible and producing a habitat map for each respective year (Hatten and others, 2010). Habitat maps were created by applying a 40-percent probability threshold to the continuous probability grids output by the satellite model using the same methodology as the regionwide modeling effort. Finally, 95-percent confidence intervals (CIs) were calculated for the habitat time series and actual (Virgin River) and simulated (upper Gila River) habitat quantities were compared to the historical baseline. This approach allowed me to determine just how much of an impact beetles have had (lower Virgin River) and may have (upper Gila River) compared to the baseline variability caused by natural (for example drought, floods) and anthropogenic (for example, fire) stressors. Given the size of the three modeled reaches (65-549 ha), they were divided into distinct zones in order to compare changes at a finer scale.

\section{Virgin River Beetle-Impact Analysis}

The Virgin River beetle-impact analysis had three distinct objectives:

1. To examine how beetles affected predicted flycatcher habitat upstream of Lake Mead where they have occurred since 2008 (Bateman and others, 2013);

2. To determine how much NDVI values decreased in this reach so the same reduction factor could be applied to unaffected reaches in other parts of the State, thereby simulating beetle impacts for management purposes; and

3. To determine how much beetles affected flycatcher habitat by comparing the post-beetle habitat to a habitat time series from 1986 to 2015.

For the first objective, a $65-\mathrm{km}$ reach along the lower Virgin River was examined, from the Narrows (about $8 \mathrm{~km}$ upstream of Beaver Dam Wash) downstream to the Lake Mead National Recreation Area boundary. Changes in flycatcher habitat were assessed within seven zones separated by tributary junctions (fig. 8). For the second objective, habitat change detection (cell-by-cell) was done from 2010 to 2015 in an area severely impacted by beetles (Nagler and others, 2014). Although beetles were first observed along the lower Virgin River in 2008, the habitat time series did not show beetle effects until 2011, which is consistent with previous research along this reach (Dobbs and others, 2012; Bateman and others, 2013; Bateman and Johnson, 2015), with radical habitat decreases occurring from 2013 to 2015. Thus, for change detection, 2010 was selected as the pre-beetle flycatcher habitat map and 2015 was selected as the post-beetle habitat map. For the second objective, I quantified how the mean NDVI values changed from 2010 to 2015 in areas the satellite model predicted suitable in 2010 but were unsuitable in 2015, which I call an NDVI reduction factor. For the third objective, a habitat time series was created from 1986 to 2015, which required that two Landsat scenes be mosaicked together for each year since the study reach cut across two Landsat footprints (path rows 3934 and 3935). The Landsat metadata associated with the Virgin River habitat time series are presented in appendix A, table A4. 


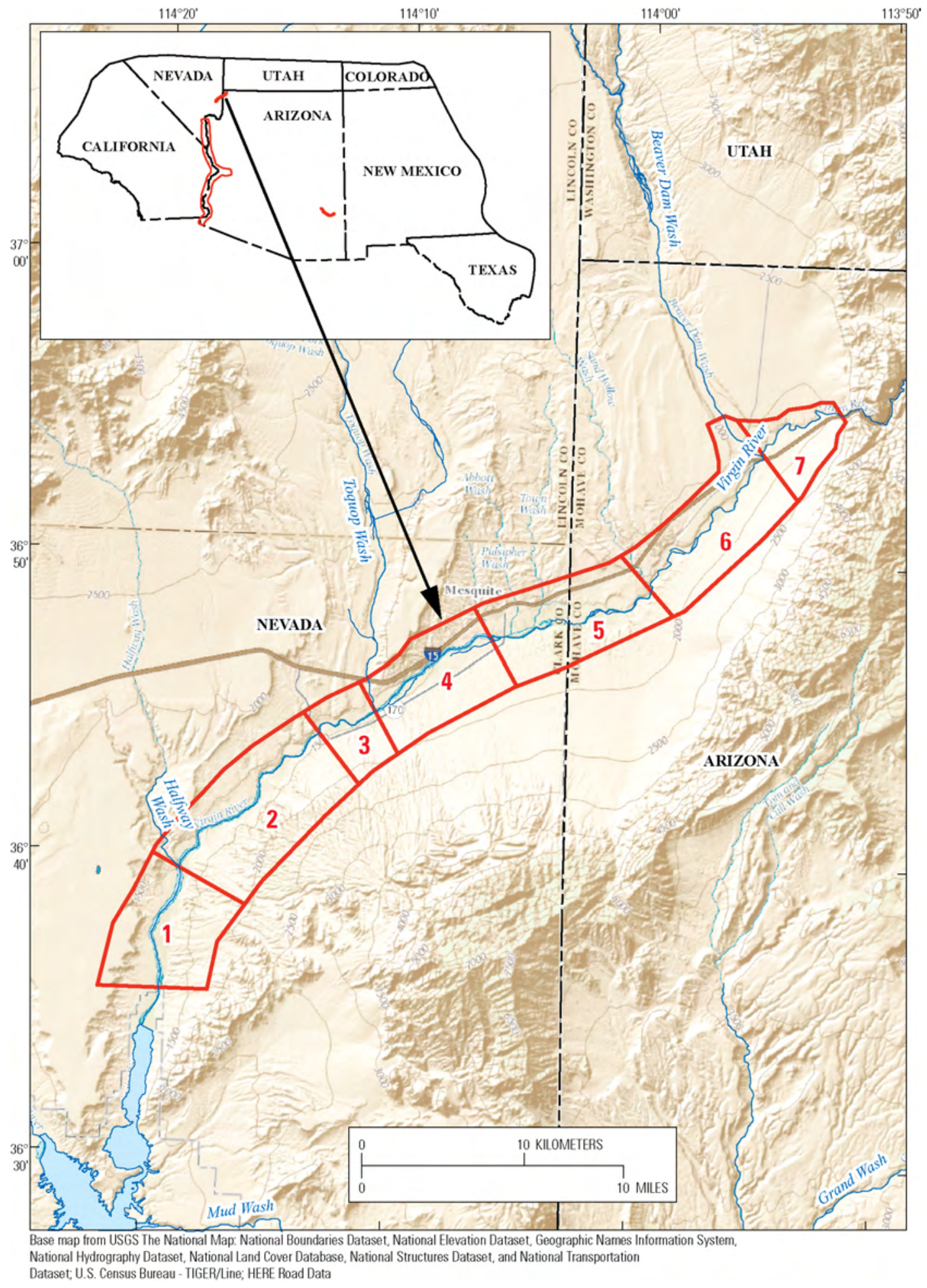

Figure 8. Map showing boundary (polygon with seven segments) of lower Virgin River where a habitat time series was calculated and a change detection was done, Nevada and Arizona, 1986-2015. Seven zones were used to calculate changes along length of Virgin River. 


\section{Lower Colorado River Beetle-Impact Simulation}

The potential effects of beetles on predicted flycatcher habitat along 549 river kilometers (341 river miles $)$ of the Lower Colorado River were simulated, from US Route 93(0.5 km downstream of Hoover Dam) to the Mexico border (fig. 9). This river section cuts across four Landsat scenes (pathrows $3935,3936,3836,3837$ ), so they were mosaicked together prior to running the satellite model (acquired in June and July 2015). This analysis differed from the Virgin and Gila River analyses in that the model was only run twice - once with unmodified imagery that represents pre-beetle riparian conditions, and once after the imagery was modified (that is, the NDVI reduction factor was applied before rerunning the model) to simulate beetle impacts on riparian vegetation. The FWS management unit boundaries were used to divide the lower Colorado River into four zones: Lower Gila, ParkerMexico, Bill Williams, and Hoover-Parker.

Tamarisk locations were obtained for the beetle-impact simulation from a previous mapping effort that used 1-m resolution 2010 National Agriculture Imagery Program (NAIP) imagery, plus higher resolution imagery from 2011 (ESRI World Imagery) to assist with structural labels (Bangle and others, 2014). The authors used Trimble eCognition ${ }^{\circledR}$ to develop vegetation community maps similar to those developed along the Lower Colorado River in 1981 (Anderson and Ohmart, 1984). For consistency, Bangle and others (2014) selected minimum mapping units of 10 acres for cottonwood/willow/mesquite, 1 acre for marsh and water-related classes, and 25 acres for all other vegetation types (for example, tamarisk). A lack of funding prevented an accuracy assessment of the vegetation map, but it is considered to be the highest-quality vegetation map to date for the study area. 


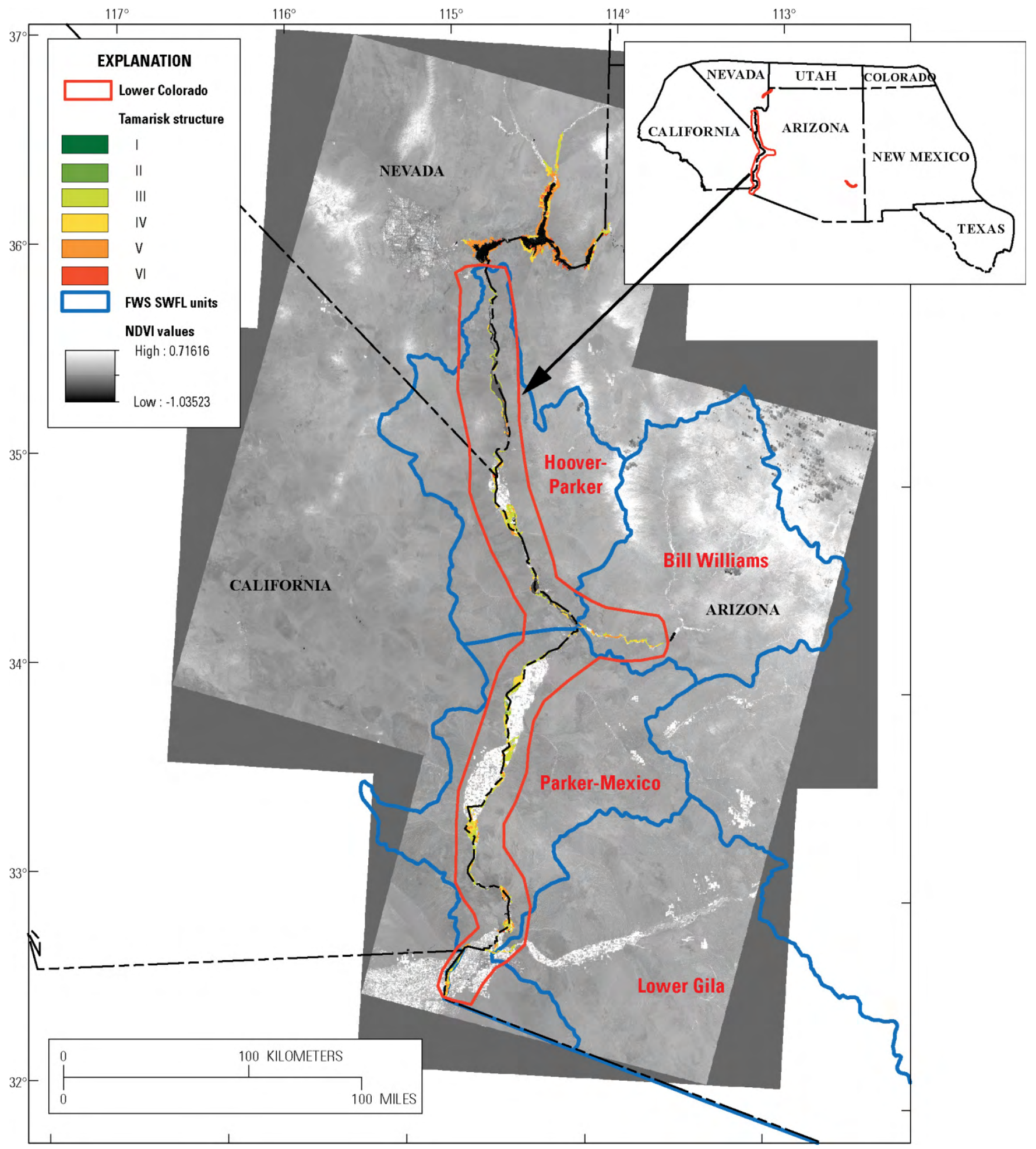

Figure 9. Map showing Lower Colorado River boundary, tamarisk patches and structure (I-VI), U.S. Fish and Wildlife Service (FWS) Southwestern Willow Flycatcher (SWFL) management unit boundaries overlaid on a normalized difference vegetation index (NDVI) image obtained July 2015, California, Nevada, and Arizona. 


\section{Upper Gila River Beetle-Impact Simulation}

The potential effects of beetles on predicted flycatcher habitat were simulated along a 71-km reach of the upper Gila River, from the confluence of Bonita Creek downstream to Goodwin Wash (about $7 \mathrm{~km}$ downstream of Fort Thomas). The magnitude of change in predicted flycatcher habitat was examined after the beetle-impact simulation (using same method as described previously) by comparing results to the historical average and annual variability in flycatcher habitat. Specifically, a 30-year habitat time series was created on the upper Gila River (fig. 10), from 1986 to 2015, with Landsat imagery and the satellite model. Twenty-four of 29 Landsat scenes were obtained in June, with the remainder occurring in May, July, or August. The Landsat metadata associated with the upper Gila River habitat time series are presented in appendix A, table A5. Image quality was high for all dates, with the exception of 2012, which was omitted because of a lapse in Landsat 5 and Landsat 8 coverage. The natural variability in flycatcher habitat was calculated annually with a habitat time series, a bar graph was created of the time series, and a 95-percent CI was calculated for the historical record (19852015). Finally, the post-beetle flycatcher habitat simulation was plotted and this result was compared to the historical habitat time series.

The tamarisk locations used in the beetle-impact simulation are derived from an earlier vegetation mapping effort during late summer 2012 (Neale and others, 2014). High-resolution multispectral imagery $(0.16 \mathrm{~m})$ and $1-\mathrm{m}$ resolution digital elevation data (obtained from lidar) were obtained on October 2, ortho-rectified, and co-registered. Field work was done in May 2013 to obtain comprehensive ground truth data, with dozens of locations visited. Trimble eCognition ${ }^{\circledR}$, object-based image analysis techniques were used to classify the remotely sensed data, sorting vegetation into 11 classes:

1. Bare ground/sparse vegetation,

2. Cottonwood/Gooddings willow,

3. Defoliated vegetation,

4. Grass/forb/low vegetation,

5. Riparian grasses,

6. Riparian willow,

7. Shadow,

8. Sparse shrub vegetation,

9. Tamarisk,

10. Water, and

11. Willow.

Like the vegetation map for the Colorado River, the Gila River map was not assessed for accuracy, but it has been used extensively by the Gila Watershed Partnership for restoration activities and is considered to be the best map available (Orr and others, 2014). 


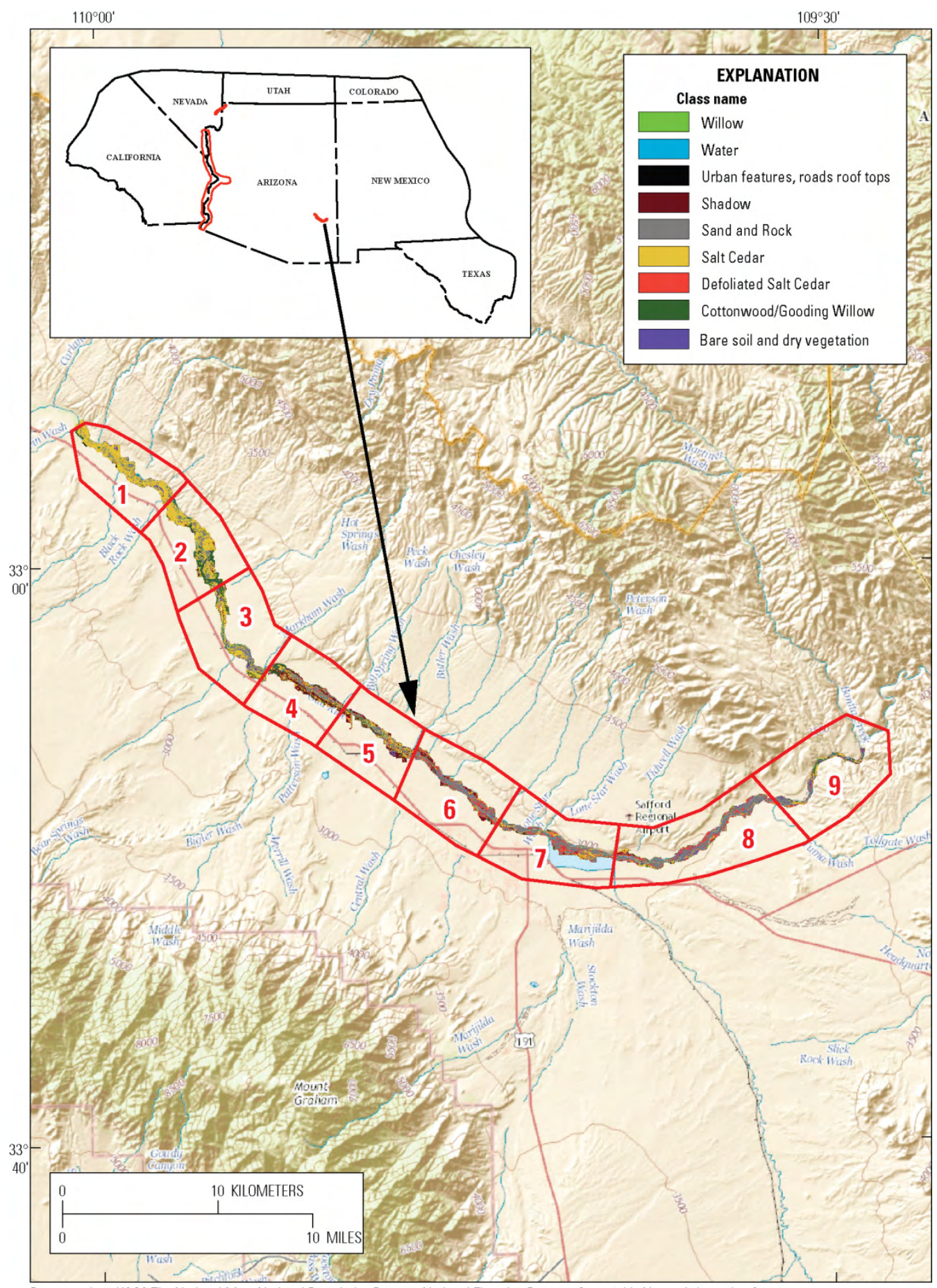

Base map from USGS The National Map: National Boundaries Dataset, National Elevation Dataset, Geographic Names Information System,

National Hydrography Dataset, National Land Cover Database, National Structures Dataset, and National Transportation

Dataset; U.S. Census Bureau - TIGER/Line; HERE Road Data

Figure 10. Map showing project boundary, nine river reaches used in tamarisk leaf beetle-impact simulation, and nine vegetation classes, upper Gila River, Arizona, 1986-2015. 


\section{Results}

\section{Satellite-Based Habitat Predictions}

\section{Rangewide}

Rangewide predicted flycatcher habitat was $476.5 \mathrm{~km}^{2}$ (40-percent threshold) in $2013,502.5$ $\mathrm{km}^{2}$ in 2014 , and $756.5 \mathrm{~km}^{2}$ in 2015 . Thus, predicted habitat was 5.5 percent more in 2014 than in 2013, and 58.8 percent more in 2015. Summarized by State, the area of predicted habitat in 2015 (below 1,524-m elevation), was least in Colorado, followed in ascending order by Utah, Nevada, Texas, California, Arizona, and New Mexico (fig. 11). This rank order remained almost the same when all elevations were considered, except for Colorado, where the predicted habitat was only $1.2 \mathrm{~km}^{2}$ below 1,524-m elevation, but $243.4 \mathrm{~km}^{2}$ above $1,524-\mathrm{m}$ elevation.

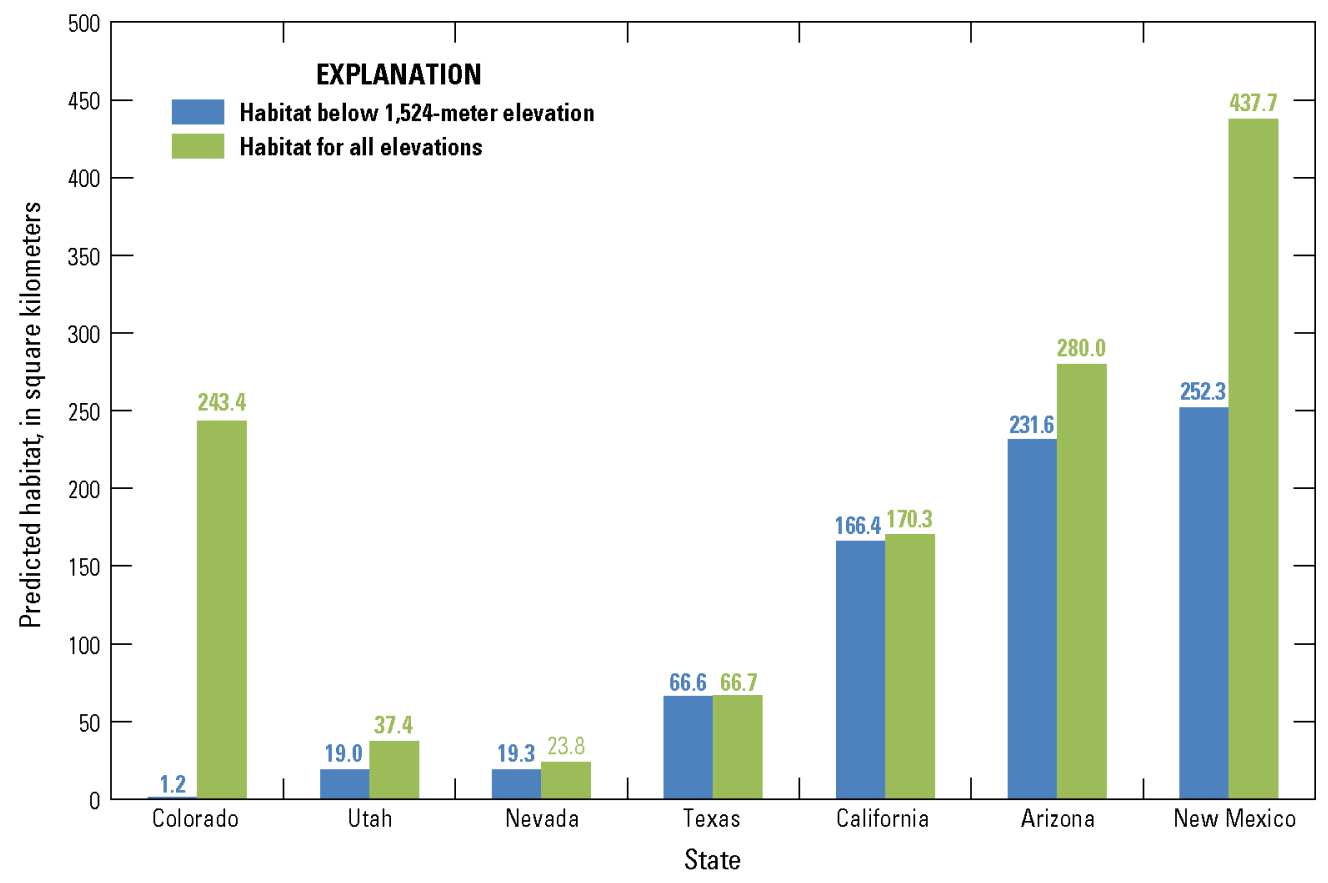

Figure 11. Graph showing area of predicted flycatcher breeding habitat below 1,524-meter elevation and for all elevations by State. Number above each bar is area of predicted habitat in square kilometers. 


\section{U.S. Fish and Wildlife Service Management Units}

Summarized by 35 FWS management units, the first, second, and third most predicted habitats below 1,524-m elevation were the Middle Rio Grande, Upper Gila, and Middle Gila/San Pedro management units in 2013 and 2014 (table 1; fig. 12). In 2015, this pattern was the same except for a large increase in predicted habitat in the Pecos management unit (New Mexico and Texas). Three management units are at elevations above the 1,524-m contour (Upper Rio Grande [New Mexico and Colorado], San Luis Valley [New Mexico and Colorado], and Dolores [Colorado]), without any lowelevation habitat. In contrast, 10 low-elevation management units (below 1,524-m elevation) have no high-elevation habitat. Predicted flycatcher habitat increased in 22 of 33 management units (66.7 percent) below 1,524-m elevation from 2013 to 2015 (four units were excluded because they were too high), with the remainder showing a decrease (fig. 13). In contrast, predicted flycatcher habitat decreased in 6 of 28 management units ( 21.4 percent) at elevations above the 1,524-m contour ( 9 units were excluded because they were too low), and 21 of 27 (77.7 percent) increased in predicted habitat. 

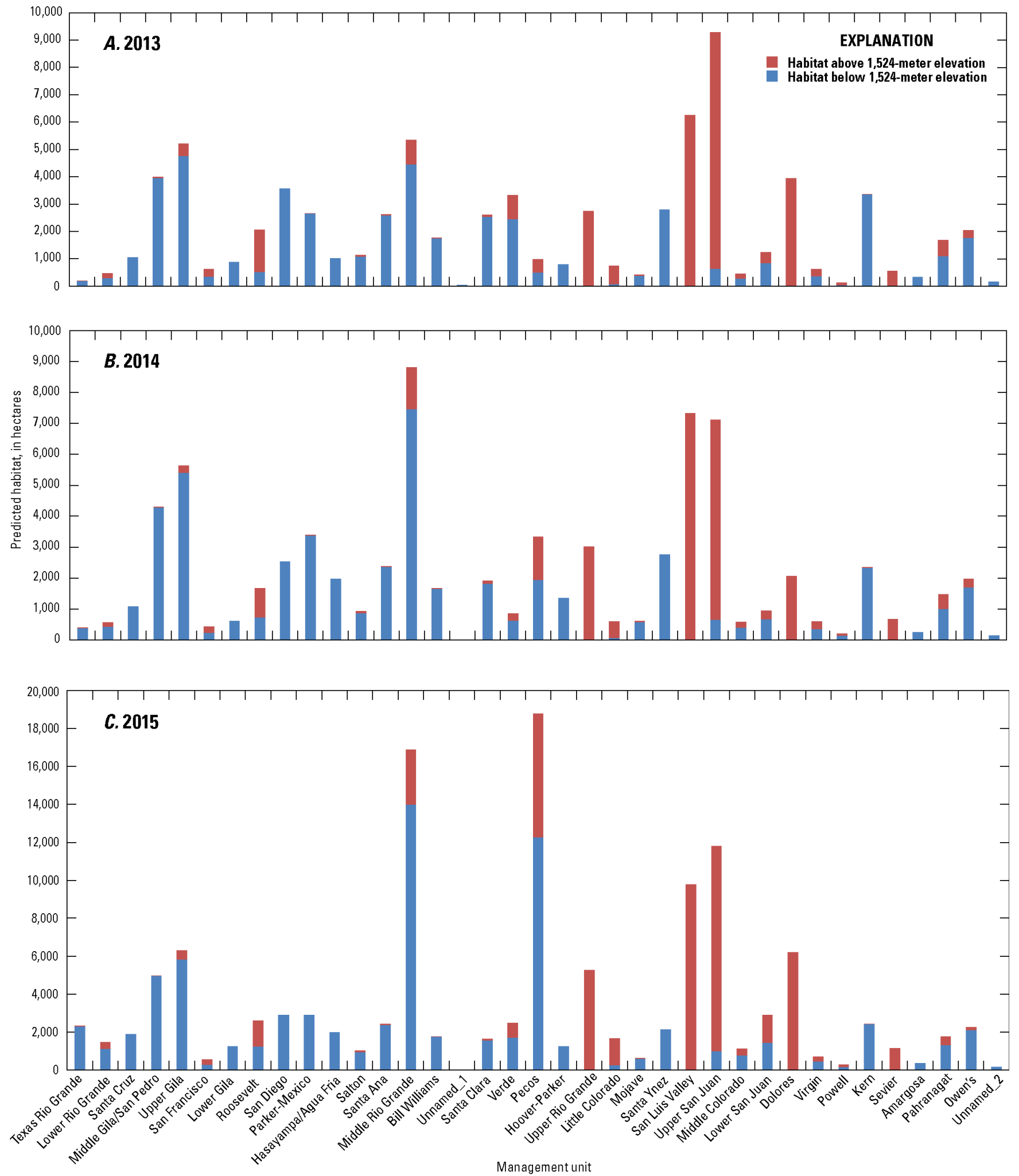

Figure 12. Graphs showing area of predicted flycatcher breeding habitat in U.S. Fish and Wildlife Service management units below and above 1,524-meter elevation, Southwestern United States, 2013-15. 
Table 1. Changes in predicted flycatcher habitat in U.S. Fish and Wildlife Service management units, Southwestern United States, 2013-15.

[2013_a, 2014_a, and 2015_a: Predicted habitat (hectares) below 1,524-meter (m) elevation for each given year. 2013_c, 2014_c, and 2015_c: Predicted habitat (hectares) above 1,524-m elevation for each given year. $\Delta$ _below: Change (in percent) below 1,524-m elevation. $\Delta_{-}$above: Change (in percent) above 1,524-m elevation. Data obtained with a satellite model at a 40 -percent probability threshold. NA, not applicable]

\begin{tabular}{|c|c|c|c|c|c|c|c|c|}
\hline \multirow{2}{*}{ Management unit } & \multicolumn{6}{|c|}{ Habitat area (hectares) } & \multicolumn{2}{|c|}{ Change (percent) } \\
\hline & 2013_a & 2014_a & 2015_a & 2013_c & 2014_c & $2015 \_c$ & $\Delta$ _below & $\Delta$ _above \\
\hline Texas Rio Grande & 190.35 & 390.06 & $2,313.90$ & 0.81 & 3.51 & 15.48 & 11.16 & 18.11 \\
\hline Lower Rio Grande & 306.99 & 429.84 & $1,108.62$ & 163.98 & 137.79 & 365.94 & 2.61 & 1.23 \\
\hline Santa Cruz & $1,054.98$ & $1,077.75$ & $1,877.22$ & 0.00 & 0.00 & 0.00 & 0.78 & NA \\
\hline Middle Gila/San Pedro & $3,963.51$ & $4,284.81$ & $4,971.24$ & 26.10 & 22.32 & 2.52 & 0.25 & -0.90 \\
\hline Upper Gila & $4,769.91$ & $5,405.04$ & $5,836.68$ & 432.54 & 230.67 & 452.07 & 0.22 & 0.05 \\
\hline San Francisco & 354.87 & 240.39 & 278.37 & 269.91 & 190.35 & 282.51 & -0.22 & 0.05 \\
\hline Lower Gila & 874.80 & 618.57 & $1,234.80$ & 0.00 & 0.00 & 0.00 & 0.41 & NA \\
\hline Roosevelt & 522.36 & 727.11 & $1,229.40$ & $1,528.02$ & 945.72 & $1,363.14$ & 1.35 & -0.11 \\
\hline San Diego & $3,566.61$ & $2,541.24$ & $2,903.67$ & 0.00 & 0.00 & 0.00 & -0.19 & NA \\
\hline Parker-Mexico & $2,655.18$ & $3,383.46$ & $2,897.10$ & 0.72 & 0.36 & 0.00 & 0.09 & -1.00 \\
\hline Hasayampa/Agua Fria & $1,012.95$ & $1,971.54$ & $1,983.87$ & 0.00 & 0.00 & 0.00 & 0.96 & NA \\
\hline Salton & $1,086.66$ & 874.71 & 957.15 & 52.56 & 58.86 & 57.69 & -0.12 & 0.10 \\
\hline Santa Ana & $2,600.37$ & $2,371.41$ & $2,371.14$ & 16.83 & 12.69 & 63.27 & -0.09 & 2.76 \\
\hline Middle Rio Grande & $4,452.21$ & $7,456.95$ & $13,999.95$ & 893.34 & $1,345.59$ & $2,896.29$ & 2.14 & 2.24 \\
\hline Bill Williams & $1,762.65$ & $1,662.57$ & $1,748.34$ & 5.67 & 8.46 & 8.28 & -0.01 & 0.46 \\
\hline Santa Clara & $2,535.21$ & $1,823.85$ & $1,562.40$ & 71.55 & 81.18 & 72.54 & -0.38 & 0.01 \\
\hline Verde & $2,461.59$ & 625.86 & $1,710.36$ & 871.74 & 232.29 & 772.92 & -0.31 & -0.11 \\
\hline Pecos & 502.56 & $1,940.31$ & $12,269.25$ & 474.03 & $1,396.98$ & $6,513.30$ & 23.41 & 12.74 \\
\hline Hoover-Parker & 790.56 & $1,355.85$ & $1,232.46$ & 0.00 & 0.00 & 0.00 & 0.56 & 0.00 \\
\hline Upper Rio Grande & 0.00 & 0.00 & 0.00 & $2,736.81$ & $3,019.41$ & $5,257.71$ & NA & 0.92 \\
\hline Little Colorado & 69.84 & 72.63 & 249.21 & 676.89 & 514.71 & $1,420.02$ & 2.57 & 1.10 \\
\hline Mojave & 388.08 & 582.84 & 600.30 & 32.31 & 34.74 & 31.05 & 0.55 & -0.04 \\
\hline Santa Ynez & $2,805.66$ & $2,757.51$ & $2,127.15$ & 0.00 & 0.00 & 0.00 & -0.24 & 0.00 \\
\hline San Luis Valley & 0.00 & 0.00 & 0.00 & $6,256.62$ & $7,323.84$ & $9,772.29$ & NA & 0.56 \\
\hline Upper San Juan & 634.59 & 650.97 & 988.11 & $8,654.49$ & $6,457.05$ & $10,815.12$ & 0.56 & 0.25 \\
\hline Middle Colorado & 269.82 & 400.14 & 784.62 & 185.94 & 180.72 & 327.87 & 1.91 & 0.76 \\
\hline Lower San Juan & 847.98 & 679.50 & $1,450.98$ & 385.74 & 270.90 & $1,448.91$ & 0.71 & 2.76 \\
\hline Dolores & 0.00 & 0.00 & 0.00 & $3,939.21$ & $2,058.30$ & $6,211.62$ & NA & 0.58 \\
\hline Virgin & 374.13 & 361.53 & 450.63 & 251.55 & 226.35 & 256.59 & 0.20 & 0.02 \\
\hline Powell & 42.21 & 138.42 & 147.42 & 75.24 & 71.91 & 126.09 & 2.49 & 0.68 \\
\hline Kern & $3,363.84$ & $2,338.38$ & $2,423.97$ & 4.14 & 3.15 & 6.93 & -0.28 & 0.67 \\
\hline Sevier & 0.00 & 0.00 & 0.00 & 550.89 & 666.27 & $1,140.39$ & NA & 1.07 \\
\hline Amargosa & 338.04 & 247.14 & 360.36 & 0.00 & 0.00 & 0.00 & 0.07 & NA \\
\hline Pahranagat & $1,098.54$ & 996.93 & $1,329.30$ & 580.68 & 471.96 & 442.35 & 0.21 & -0.24 \\
\hline Owen's & $1,777.50$ & $1,701.09$ & $2,101.05$ & 264.33 & 277.20 & 154.98 & 0.18 & -0.41 \\
\hline
\end{tabular}




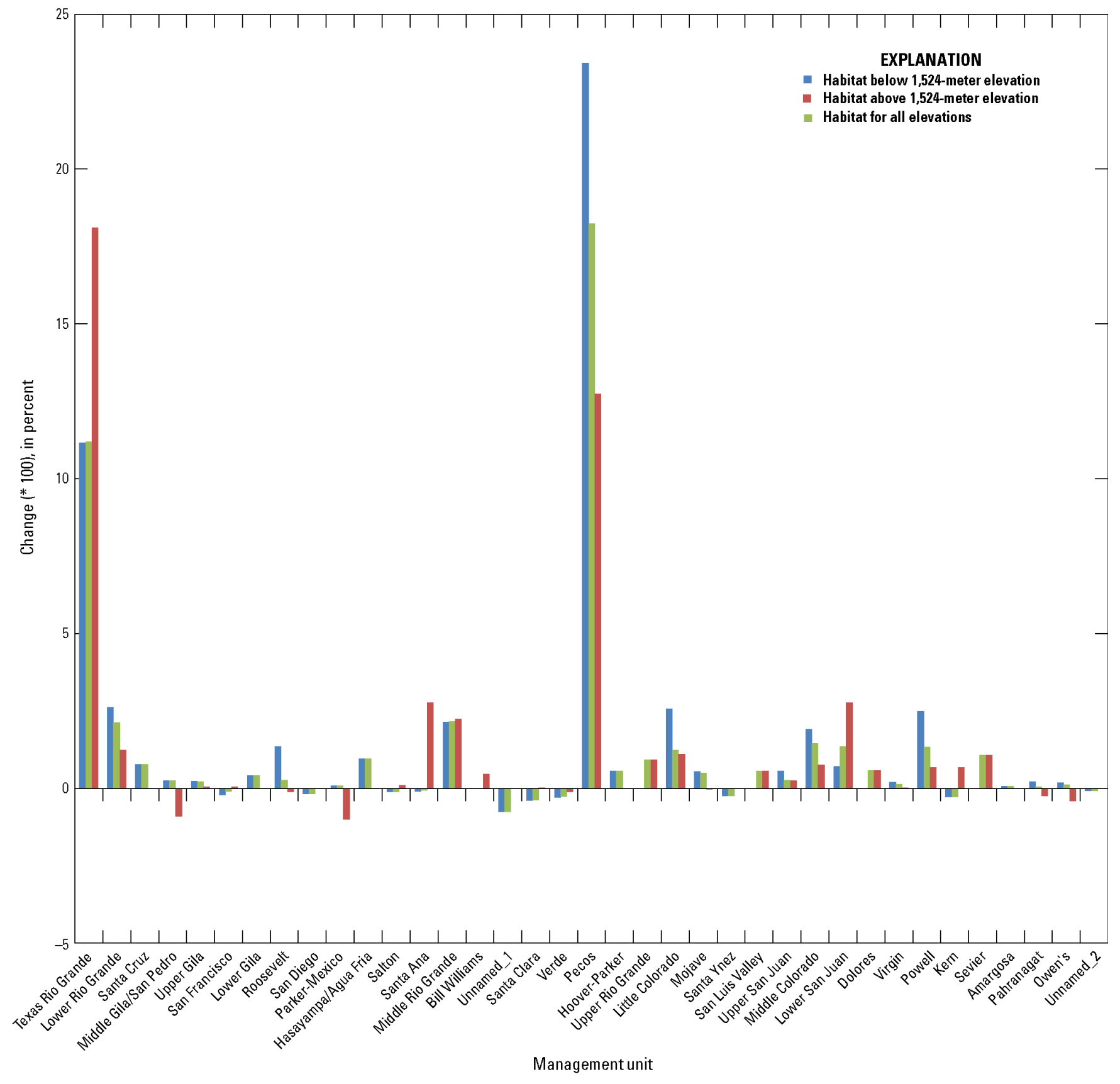

Figure 13. Graph showing changes in predicted flycatcher breeding habitat in U.S. Fish and Wildlife Service management units below and above 1,524-meter elevation and for all elevations, 2013-15. 


\section{5-Minute Quadrangles}

Summarized by 7.5-minute quadrangles, there was no predicted flycatcher habitat at any elevation from 2013 to 2015 in 69.4 percent $(4,422)$ of the 6,521 quadrangles in the project area, but one must consider that masking excluded habitat predictions on streams smaller than $4^{\text {th }}$ order or waterbodies less than $1 \mathrm{~km}^{2}$. These numbers changed when locations below 1,524-m elevation were examined, with no predicted habitat in 79.9 percent $(5,212)$ of the quadrangles. The area of predicted flycatcher habitat ranged from 0.1 to 1,398 ha in a checkerboard pattern (fig. 14). Of the 50 top-ranked quadrangles below 1,524-m elevation (rank), predicted flycatcher habitat was 42 percent (21) in Arizona, 32 percent (16) in New Mexico, 22 percent (11) in California, and 2 percent (1) in Utah and Nevada, respectively (fig. 15; table 2). The 10 top-ranked quadrangles in descending order were Paraje Well and San Marcial (New Mexico; fig. 16A), San Carlos Reservoir (southeastern Arizona; fig. 16B), Corona North (California), Romero Canyon (New Mexico), Lake Mcmillan North (New Mexico), Prado Dam (California), Weldon (California), Needles (Arizona), and Dewey Flat (Arizona) (table 2). 


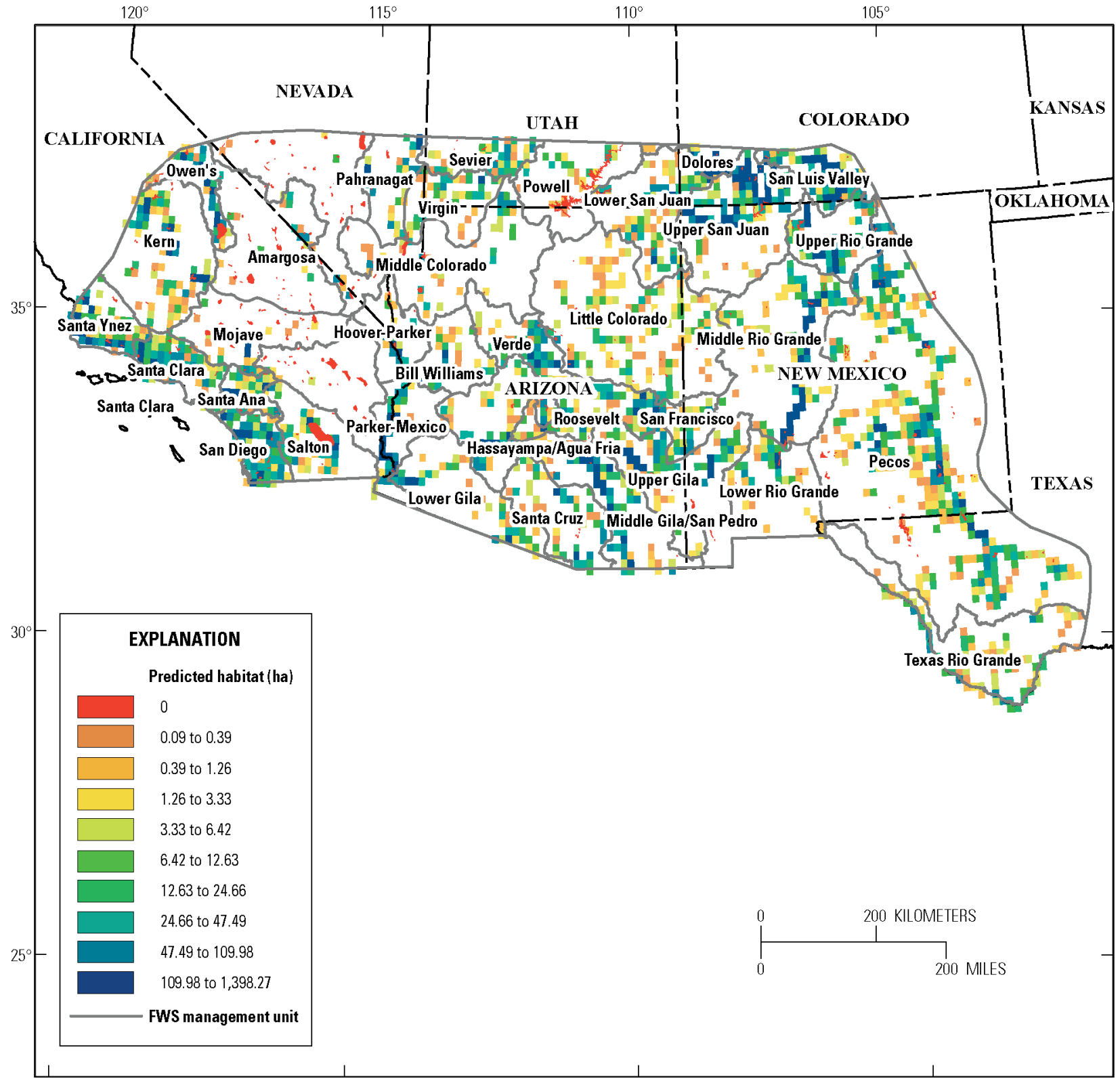

Figure 14. Map showing area of predicted flycatcher breeding habitat (averaged across 2013-15) at all elevations in 6,521 U.S. Geological Survey 7.5-minute quadrangles, Southwestern United States. Only areas within a prescribed distance of streams and greater than stream-order 3, or within 1 kilometer of a lake or reservoir, were included in this analysis. Areas outside the selection criteria are excluded (white), and areas with no habitat are 0 (red). 


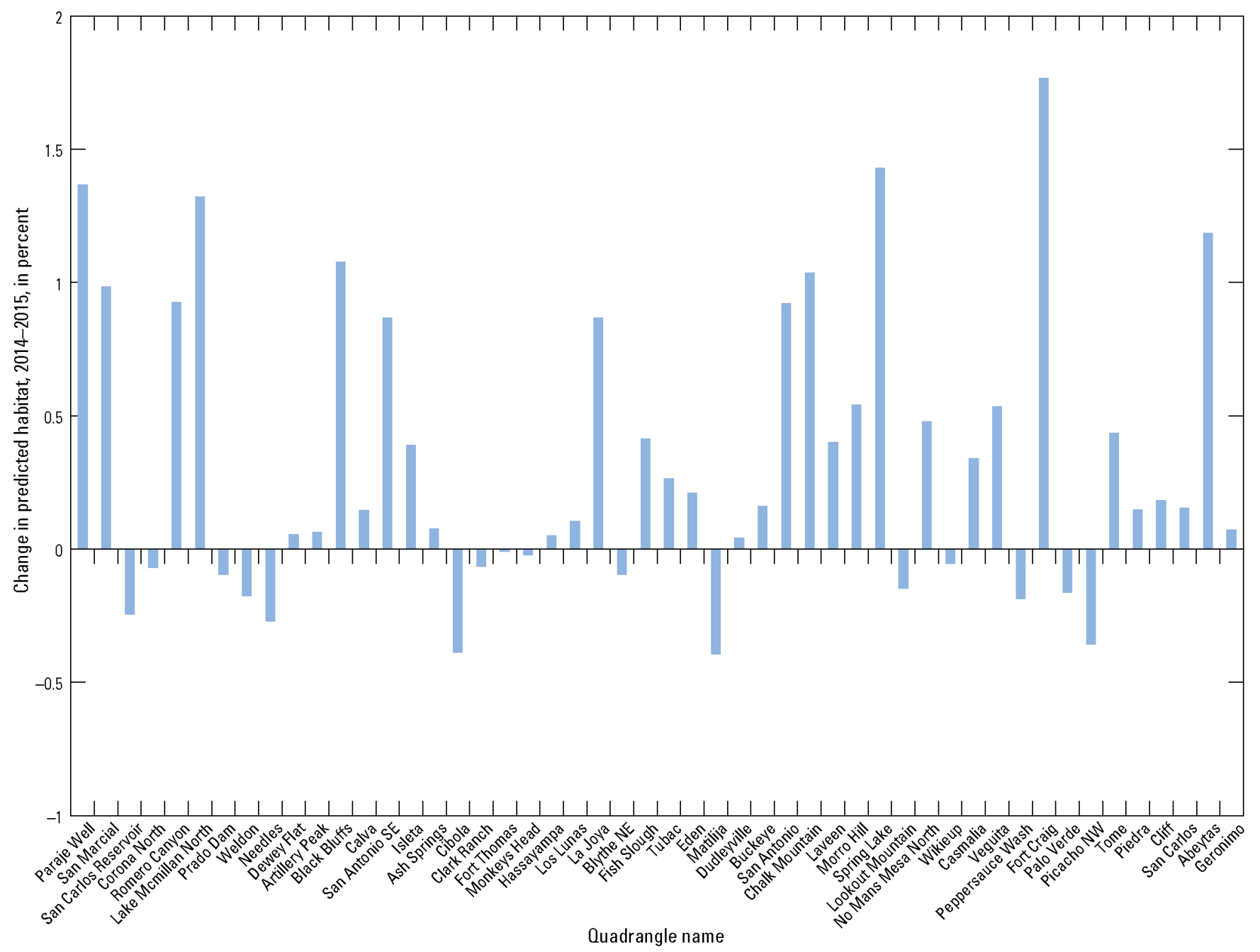

Figure 15. Graph showing changes in predicted flycatcher habitat for the 50 top-ranked U.S. Geological Survey 7.5-minute quadrangles below 1,524-meter elevation, 2014-15. Predicted flycatcher habitat increased in 34 quadrangles (68 percent) and decreased in 16 quadrangles (32 percent). 

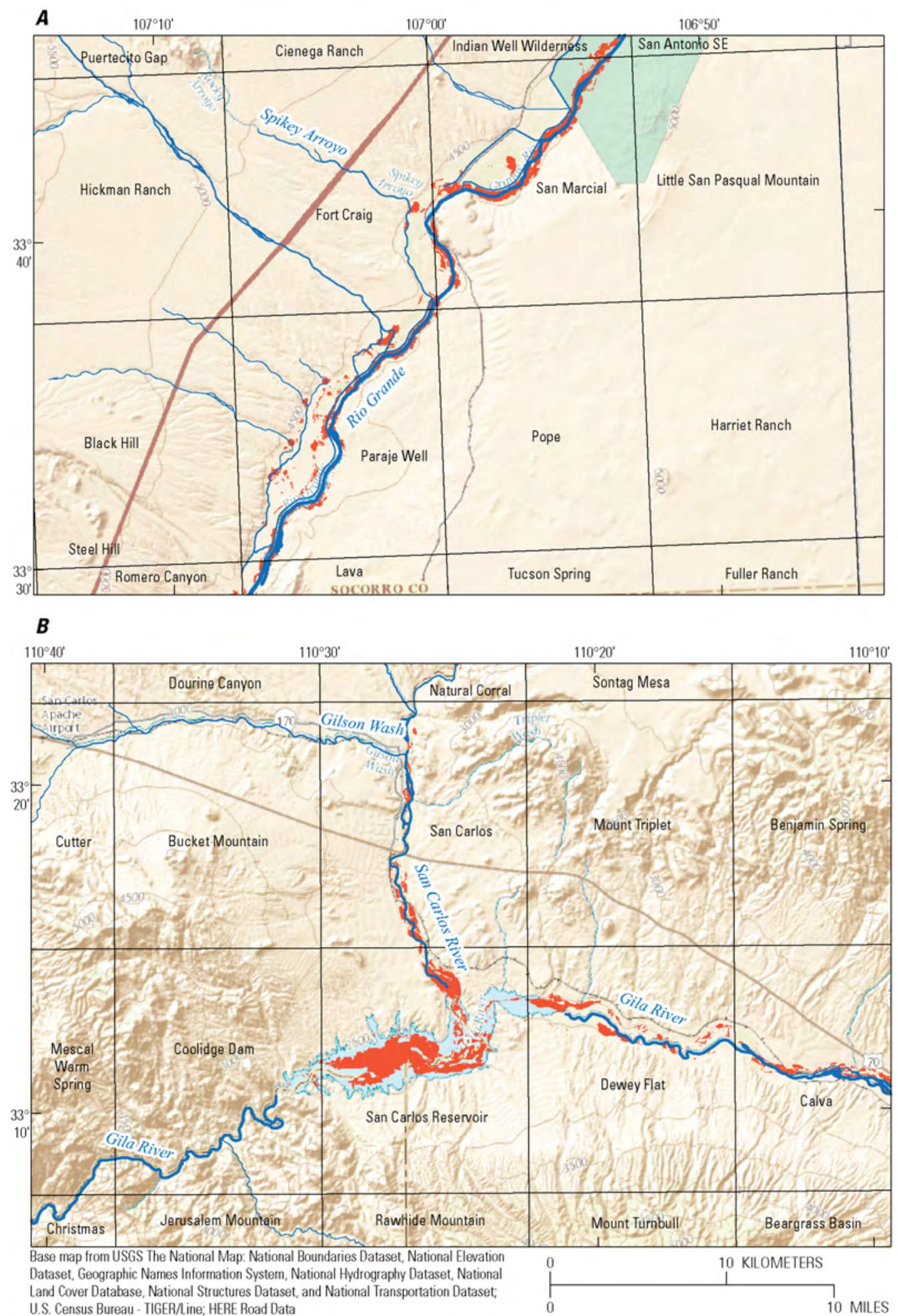

Figure 16. Maps showing predicted flycatcher breeding habitat at (A) Paraje Well and San Marcial, New Mexico, June 2013, and (B) San Carlos Reservoir, south-central Arizona. The 7.5-minute U.S. Geological Survey quadrangles and their names are overlaid. 
Table 2. Top-ranked 50 7.5-minute U.S. Geological Survey quadrangles by average area (hectares) of predicted flycatcher habitat, Southwestern United States, 2013-15.

[Habitat estimates were obtained from the satellite model at a 40-percent probability threshold. USGS_QD_ID: Quadrangle identification number. QUAD_NAME: Quadrangle name. ST_NAME State in which quadrangle occurs. 3yravg_p40: Average area (hectares) of flycatcher habitat in quadrangles below 1,524-meter elevation shown in descending order]

\begin{tabular}{|c|c|c|c|}
\hline USGS_QD_ID & QUAD_NAME & ST_NAME & 3yravg_p40 \\
\hline 33107-E1 & Paraje Well & New Mexico & $1,398.27$ \\
\hline $33106-\mathrm{F} 8$ & San Marcial & New Mexico & $1,331.97$ \\
\hline 33110-B4 & San Carlos Reservoir & Arizona & $1,030.47$ \\
\hline 33117-H5 & Corona North & California & 943.53 \\
\hline 33107-D2 & Romero Canyon & New Mexico & 907.8 \\
\hline 32104-F3 & Lake McMillan North & New Mexico & 759.87 \\
\hline 33117-H6 & Prado Dam & California & 655.98 \\
\hline 35118-F3 & Weldon & California & 633.33 \\
\hline 34114-G5 & Needles & Arizona & 585.69 \\
\hline 33110-B3 & Dewey Flat & Arizona & 578.82 \\
\hline $34113-\mathrm{C} 5$ & Artillery Peak & Arizona & 569.4 \\
\hline $33107-\mathrm{C} 2$ & Black Bluffs & New Mexico & 569.31 \\
\hline $33110-\mathrm{B} 2$ & Calva & Arizona & 567.03 \\
\hline $33106-G 7$ & San Antonio SE & New Mexico & 536.85 \\
\hline 34106-H6 & Isleta & New Mexico & 534.27 \\
\hline 37115-D2 & Ash Springs & Nevada & 513.57 \\
\hline 33114-C6 & Cibola & Arizona & 470.46 \\
\hline $32110-F 5$ & Clark Ranch & Arizona & 460.38 \\
\hline $33109-A 8$ & Fort Thomas & Arizona & 447.78 \\
\hline $34114-\mathrm{C} 1$ & Monkeys Head & Arizona & 440.61 \\
\hline 33112-C6 & Hassayampa & Arizona & 427.89 \\
\hline 34106-G6 & Los Lunas & New Mexico & 416.19 \\
\hline $34106-\mathrm{C} 7$ & La Joya & New Mexico & 404.94 \\
\hline 33114-F5 & Blythe NE & California & 400.02 \\
\hline 37118-D4 & Fish Slough & California & 376.47 \\
\hline 31111-E1 & Tubac & Arizona & 375.63 \\
\hline 32109-H8 & Eden & Arizona & 372.12 \\
\hline 34119-D3 & Matilija & California & 365.16 \\
\hline 32110-H6 & Dudleyville & Arizona & 363.15 \\
\hline $33112-\mathrm{C} 5$ & Buckeye & Arizona & 358.2 \\
\hline 33106-H7 & San Antonio & New Mexico & 337.56 \\
\hline 34111-A6 & Chalk Mountain & Arizona & 320.43 \\
\hline $33112-\mathrm{C} 2$ & Laveen & Arizona & 315.87 \\
\hline $33117-\mathrm{C} 3$ & Morro Hill & California & 313.74 \\
\hline 32104-G3 & Spring Lake & New Mexico & 312.51 \\
\hline $32110-\mathrm{G} 6$ & Lookout Mountain & Arizona & 308.22 \\
\hline
\end{tabular}




\begin{tabular}{cllc}
\hline USGS_QD_ID & \multicolumn{1}{c}{ QUAD_NAME } & \multicolumn{1}{c}{ ST_NAME } & 3yravg_p40 \\
\hline 37110-B5 & No Mans Mesa North & Utah & 306.63 \\
34113-F5 & Wikieup & Arizona & 304.53 \\
34120-G5 & Casmalia & California & 297.15 \\
34106-E7 & Veguita & New Mexico & 295.68 \\
32110-E5 & Peppersauce Wash & Arizona & 294.12 \\
33107-F1 & Fort Craig & New Mexico & 288.18 \\
33114-D6 & Palo Verde & California & 287.91 \\
33114-B6 & Picacho NW & California & 287.7 \\
34106-F6 & Tome & New Mexico & 284.49 \\
$36119-G 4$ & Piedra & California & 276.42 \\
32108-H5 & Cliff & New Mexico & 272.91 \\
33110-C4 & San Carlos & Arizona & 272.52 \\
34106-D7 & Abeytas & New Mexico & 267.09 \\
33110-A1 & Geronimo & Arizona & 265.83 \\
\hline
\end{tabular}

\section{U.S. Fish and Wildlife Service Critical-Habitat Reaches}

Predicted flycatcher habitat was the most in the Rio Grande recovery unit (table 3 ) when averaged across 2013-15 (8,854 ha), followed in descending order by the Gila (6,022 ha), Coastal California (2,911 ha), Little Colorado (1,416 ha), Basin and Mojave (1,258 ha), and Upper Colorado (258 ha). The top five critical-habitat reaches, ranked in descending order for predicted flycatcher habitat (averaged across 2013-15) were Middle Rio Grande (7,165 ha), San Pedro River (2,003 ha), Gila River-mid San Carlos (1,247 ha), Rio Grande-San Luis Valley National Wildlife Refuge (1,107 ha), and Santa Clara River (962 ha). Four critical-habitat reaches contained no habitat in any year: Mill Creek-Salton, Paria River, Bautista Creek-east, and Bautista Creek-west. 
Table 3. Predicted flycatcher habitat in 87 U.S. Fish and Wildlife Service critical-habitat reaches (Unit name), located within 6 recovery units and 35 management units, Southwestern United States, 2013-15.

[Critical-habitat reach locations are shown in figure 1 by reach identification number (ID No.). Predicted habitat was calculated at a 40-percent probability threshold, as determined from the satellite model. Mill Creek has the same ID No. for two management units because it was split in two in the recovery plan]

\begin{tabular}{|c|c|c|c|c|c|c|}
\hline \multirow{2}{*}{ Recovery unit } & \multirow{2}{*}{ Management unit } & \multirow{2}{*}{ Unit name } & \multicolumn{3}{|c|}{ Habitat area (hectares) } & \multirow{2}{*}{$\begin{array}{l}\text { ID } \\
\text { No. }\end{array}$} \\
\hline & & & 2013 & 2014 & 2015 & \\
\hline Basin and Mojave & Amargosa & Amargosa River & 11.6 & 2.5 & 12.2 & 25 \\
\hline Basin and Mojave & Amargosa & Ash Meadows NWR & 0.2 & 0.2 & 0.2 & 56 \\
\hline Basin and Mojave & Amargosa & Willow Creek & 10.5 & 3.0 & 10.4 & 44 \\
\hline Basin and Mojave & Kern & Canebrake Creek & 10.1 & 8.8 & 9.5 & 43 \\
\hline Basin and Mojave & Kern & Kern River South Fork & 891.2 & 646.0 & 559.8 & 13 \\
\hline Basin and Mojave & Mojave & Deep Creek & 0.0 & 0.0 & 2.6 & 48 \\
\hline Basin and Mojave & Mojave & Holcomb Creek & 5.4 & 3.9 & 6.8 & 47 \\
\hline Basin and Mojave & Mojave & Mojave River & 357.4 & 499.1 & 533.6 & 11 \\
\hline Basin and Mojave & Salton & Mill Creek & 0.0 & 0.0 & 0.0 & 79 \\
\hline Basin and Mojave & Salton & San Felipe Creek & 77.4 & 51.9 & 60.3 & 80 \\
\hline Coastal California & San Diego & Agua Hedionda Creek - east & 12.5 & 7.7 & 8.4 & 84 \\
\hline Coastal California & San Diego & De Luz Creek & 0.3 & 0.0 & 0.0 & 86 \\
\hline Coastal California & San Diego & Pilgrim Creek & 7.3 & 7.3 & 7.1 & 87 \\
\hline Coastal California & San Diego & San Diego River El Capitan - north & 11.3 & 5.6 & 10.2 & 72 \\
\hline Coastal California & San Diego & San Diego River El Capitan - south & 28.3 & 6.8 & 9.9 & 74 \\
\hline Coastal California & San Diego & San Luis Rey River - east 4 & 0.6 & 1.3 & 0.7 & 67 \\
\hline Coastal California & San Diego & San Luis Rey River - east 5 & 1.3 & 0.1 & 1.8 & 70 \\
\hline Coastal California & San Diego & San Luis Rey River - east 6 & 0.3 & 0.3 & 1.7 & 69 \\
\hline Coastal California & San Diego & San Luis Rey River - east 7 & 45.6 & 38.4 & 40.1 & 68 \\
\hline Coastal California & San Diego & San Luis Rey River - middle 3 & 1.5 & 2.1 & 1.2 & 65 \\
\hline Coastal California & San Diego & San Luis Rey River - west 1 & 378.9 & 256.1 & 265.1 & 66 \\
\hline Coastal California & San Diego & San Luis Rey River - west 2 & 43.8 & 36.1 & 30.7 & 88 \\
\hline Coastal California & San Diego & Santa Margarita River & 82.8 & 71.2 & 87.1 & 64 \\
\hline Coastal California & San Diego & Santa Ysabel Creek - east & 27.1 & 16.6 & 31.8 & 85 \\
\hline Coastal California & San Diego & Sweetwater River & 53.3 & 48.7 & 47.1 & 75 \\
\hline Coastal California & San Diego & Temecula Creek & 6.5 & 3.2 & 3.4 & 82 \\
\hline Coastal California & San Diego & Temescal Creek & 13.1 & 6.6 & 7.9 & 71 \\
\hline Coastal California & Santa Ana & Bautista Creek - east & 0.0 & 0.0 & 0.0 & 78 \\
\hline Coastal California & Santa Ana & Bautista Creek - middle & 1.0 & 0.4 & 1.6 & 77 \\
\hline Coastal California & Santa Ana & Bautista Creek - west & 0.0 & 0.0 & 0.0 & 76 \\
\hline Coastal California & Santa Ana & Bear Creek & 40.8 & 42.0 & 48.2 & 60 \\
\hline Coastal California & Santa Ana & Mill Creek & 29.3 & 30.0 & 32.8 & 79 \\
\hline Coastal California & Santa Ana & Oak Glen Creek & 15.9 & 14.6 & 12.3 & 63 \\
\hline Coastal California & Santa Ana & San Timoteo Creek & 18.4 & 17.6 & 23.1 & 81 \\
\hline Coastal California & Santa Ana & Santa Ana River - east & 50.1 & 44.6 & 55.1 & 62 \\
\hline Coastal California & Santa Ana & Santa Ana River - middle & 5.1 & 21.5 & 28.4 & 83 \\
\hline Coastal California & Santa Ana & Santa Ana River - west & 528.3 & 510.3 & 499.8 & 59 \\
\hline Coastal California & Santa Ana & Waterman Creek & 10.2 & 9.8 & 12.7 & 61 \\
\hline Coastal California & Santa Clara & Big Tujunga Canyon & 158.1 & 130.1 & 136.1 & 26 \\
\hline Coastal California & Santa Clara & Castaic Creek & 7.9 & 0.7 & 0.8 & 46 \\
\hline Coastal California & Santa Clara & Piru Creek & 10.7 & 41.0 & 61.3 & 27 \\
\hline Coastal California & Santa Clara & Santa Clara River & $1,191.9$ & 832.8 & 860.6 & 9 \\
\hline Coastal California & Santa Clara & Ventura River & 134.4 & 81.7 & 95.3 & 30 \\
\hline Coastal California & Santa Ynez & Mono Creek & 25.2 & 19.0 & 1.7 & 45 \\
\hline
\end{tabular}




\begin{tabular}{|c|c|c|c|c|c|c|}
\hline \multirow{2}{*}{ Recovery unit } & \multirow{2}{*}{ Management unit } & \multirow{2}{*}{ Unit name } & \multicolumn{3}{|c|}{ Habitat area (hectares) } & \multirow{2}{*}{$\begin{array}{l}\text { ID } \\
\text { No. }\end{array}$} \\
\hline & & & 2013 & 2014 & 2015 & \\
\hline Coastal California & Santa Ynez & Santa Ynez River - east & 97.4 & 89.1 & 60.9 & 29 \\
\hline Coastal California & Santa Ynez & Santa Ynez River - middle & 0.6 & 0.4 & 0.0 & 28 \\
\hline Coastal California & Santa Ynez & Santa Ynez River - west & 369.1 & 306.3 & 139.5 & 10 \\
\hline Gila & Hassayampa and Agua Fria & Hassayampa River & 63.9 & 43.7 & 1.4 & 23 \\
\hline Gila & Middle Gila and San Pedro & Gila River - San Pedro & 148.3 & 670.4 & 792.1 & 38 \\
\hline Gila & Middle Gila and San Pedro & San Pedro River & $2,055.3$ & $2,014.9$ & $1,939.8$ & 2 \\
\hline Gila & Roosevelt & Salt River & 17.9 & 115.7 & 305.6 & 37 \\
\hline Gila & Roosevelt & Tonto Creek & 120.2 & 145.6 & 233.6 & 36 \\
\hline Gila & San Francisco & San Francisco River - east & 76.1 & 48.2 & 114.0 & 8 \\
\hline Gila & San Francisco & San Francisco River - NE & 2.3 & 10.0 & 2.5 & 1 \\
\hline Gila & San Francisco & San Francisco River - NW & 7.3 & 23.9 & 0.0 & 49 \\
\hline Gila & San Francisco & San Francisco River - west & 50.5 & 30.2 & 13.5 & 19 \\
\hline Gila & Santa Cruz & Cienega Creek & 104.9 & 97.0 & 89.0 & 21 \\
\hline Gila & Santa Cruz & Santa Cruz River & 580.5 & 621.1 & 777.9 & 22 \\
\hline Gila & Upper Gila & Gila River - east & 169.1 & 258.3 & 313.6 & 32 \\
\hline Gila & Upper Gila & Gila River - mid San Carlos & $1,069.5$ & $1,239.2$ & $1,432.1$ & 33 \\
\hline Gila & Upper Gila & Gila River - south & 275.0 & 386.9 & 395.5 & 3 \\
\hline Gila & Verde & Verde River - middle N & 46.6 & 50.9 & 56.2 & 54 \\
\hline Gila & Verde & Verde River - middle S & 43.7 & 39.1 & 7.3 & 35 \\
\hline Gila & Verde & Verde River - upper M & 216.5 & 7.7 & 85.1 & 5 \\
\hline Gila & Verde & Verde River - upper N & 288.5 & 2.2 & 151.7 & 4 \\
\hline Gila & Verde & Verde River - upper S & 115.0 & 15.3 & 85.1 & 6 \\
\hline Little Colorado & Bill Williams & Big Sandy River - Alamo & 145.9 & 144.0 & 168.0 & 7 \\
\hline Little Colorado & Bill Williams & Big Sandy River - north & 345.2 & 334.3 & 328.1 & 40 \\
\hline Little Colorado & Bill Williams & Bill Williams River - Alamo & 268.0 & 271.8 & 276.3 & 41 \\
\hline Little Colorado & Bill Williams & Bill Williams River - Lincoln & 42.3 & 37.5 & 42.8 & 24 \\
\hline Little Colorado & Bill Williams & Bill Williams River - NWR upper & 220.1 & 186.2 & 146.8 & 55 \\
\hline Little Colorado & Bill Williams & Santa Maria River & 225.0 & 220.9 & 227.1 & 42 \\
\hline Little Colorado & Little Colorado & Little Colorado River & 40.6 & 12.3 & 35.1 & 50 \\
\hline Little Colorado & Little Colorado & Little Colorado River West Fork & 0.4 & 0.0 & 0.2 & 12 \\
\hline Little Colorado & Pahranagat & Pahranagat - NWR & 59.4 & 46.1 & 67.8 & 39 \\
\hline Little Colorado & Virgin & Virgin River & 119.9 & 109.6 & 126.7 & 34 \\
\hline Rio Grande & Middle Rio Grande & Rio Grande - middle & $3,578.0$ & $6,052.5$ & $11,864.6$ & 14 \\
\hline Rio Grande & San Luis Valley & Conejos River SLV & 230.5 & 229.1 & 348.6 & 57 \\
\hline Rio Grande & San Luis Valley & Rio Grande SLV - NWR & $1,353.1$ & 703.0 & $1,266.2$ & 15 \\
\hline Rio Grande & San Luis Valley & Rio Grande SLV - south & 1.3 & 4.6 & 46.8 & 51 \\
\hline Rio Grande & Upper Rio Grande & Coyote Creek & 34.5 & 44.1 & 63.9 & 16 \\
\hline Rio Grande & Upper Rio Grande & Rio Fernando de Taos & 1.0 & 1.2 & 2.3 & 31 \\
\hline Rio Grande & Upper Rio Grande & Rio Grande - Between Pueblos & 6.0 & 8.3 & 14.1 & 52 \\
\hline Rio Grande & Upper Rio Grande & Rio Grande - upper & 192.6 & 194.7 & 260.5 & 18 \\
\hline Rio Grande & Upper Rio Grande & Rio Grande del Rancho & 9.4 & 9.5 & 42.8 & 17 \\
\hline Upper Colorado & Powell & Paria River & 0.0 & 0.0 & 0.0 & 53 \\
\hline Upper Colorado & San Juan & Los Pinos River & 168.9 & 161.4 & 197.7 & 58 \\
\hline Upper Colorado & San Juan & San Juan River - west & 75.2 & 14.8 & 157.2 & 20 \\
\hline
\end{tabular}




\section{Model Accuracy}

At a 40-percent cutpoint (binary habitat map), 88 percent (667) of flycatcher territories were inside predicted habitat in 2014, whereas 12 percent (91) were outside predicted habitat (omission). Of the 91 territories outside predicted habitat (less than 40-percent probability), 90 percent of them (82) were in the first or second probability classes (1-39-percent probabilities), whereas 10 percent were outside any predicted habitat (0 percent). The Euclidean function in ArcGIS ${ }^{\mathrm{TM}}$ indicated that the average distance of a flycatcher territory from predicted habitat was $74 \mathrm{~m}$ (standard deviation of $74 \mathrm{~m}$ ), and the maximum distance was $277 \mathrm{~m}$ (about 9 cells). The density of flycatcher territories in 2014 was exponentially related to the five model probability classes (fig. 17), with 0.0005 territories per hectare in class 1 , and 0.0177 territories per hectare in class 5 . More than 99 percent of the variability in territory densities among the five density classes is explained in equation 2, indicating an excellent fit between model probabilities and flycatcher territories:

$$
D=0.0002 \mathrm{e}^{0.9114 \mathrm{x}}
$$

where

$D \quad$ is flycatcher territory density (number of territories per hectare), and

$X \quad$ is probability class.

The distributions of flycatcher territories are presented at five locations, overlaid on binary (40 percent probability threshold) and five-probability maps:

1. Owens River (fig. 18A-18B),

2. Alamo Lake (fig. $19 A-19 B$ ),

3. Rio Grande-Elephant Butte Reservoir (fig. 20A-20B),

4. Colorado River-Havasu National Wildlife Refuge (fig. 21A-21B), and

5. Santa Margarita and San Luis Rey Rivers (fig. 22A-22B).

Many other areas were equally compelling to visualize, but were omitted for space considerations. 


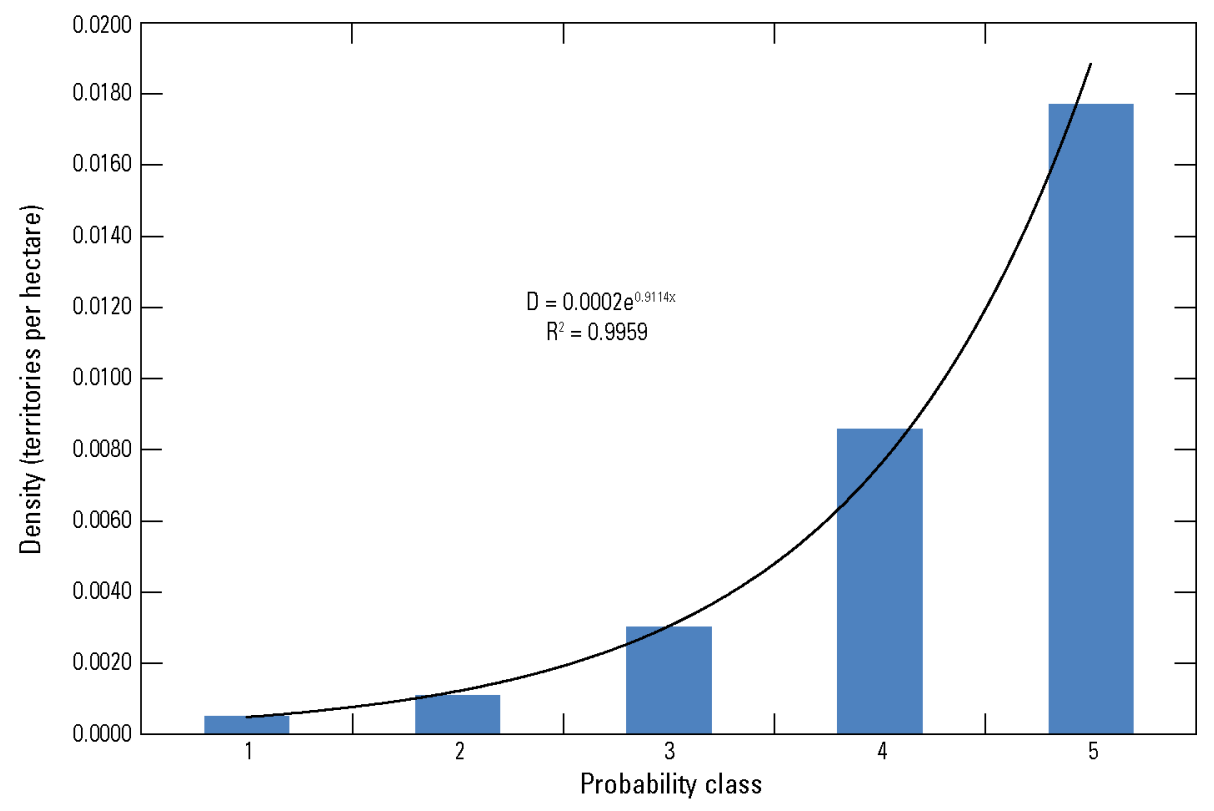

Figure 17. Graph showing density of flycatcher territories $(n=747)$ in 2014 in five probability classes output by the satellite model. 


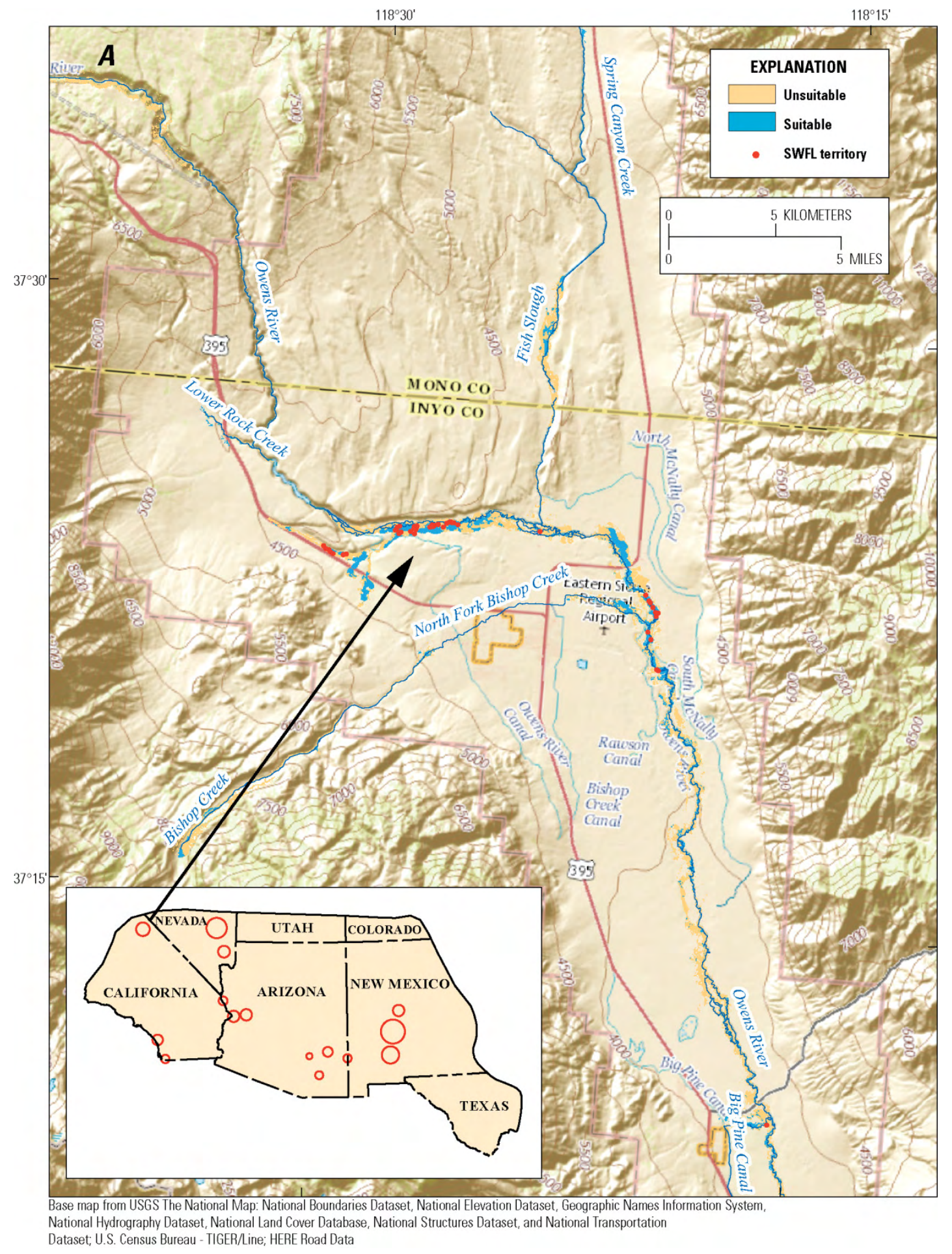

Figure 18. Flycatcher habitat suitability maps of the upper Owens River, California. $(A)$ Produced by the satellite model at a 40-percent probability threshold; cells with values greater than 40 percent are considered suitable and cells with values less than 40 percent are considered unsuitable. $(B)$ Produced at 20-percent probability thresholds; probability class 1 is the lowest ranked habitat and class 5 is the highest. Southwestern Willow Flycatcher (SWFL) territories were located in summer 2014 by the California Department of Fish and Wildlife. 


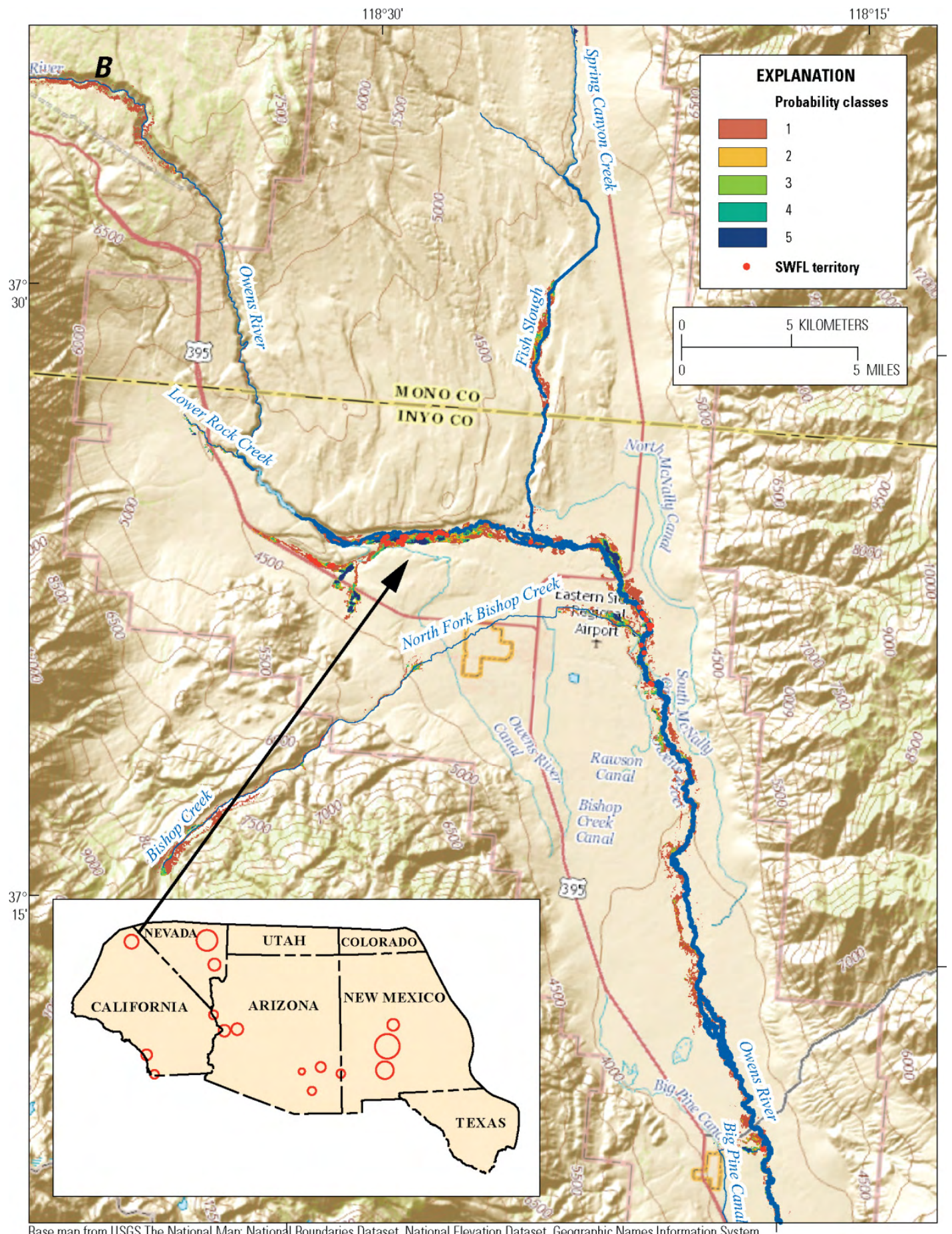

Base map from USGS The National Map: Nationdl Boundaries Dataset, National Elevation Dataset, Geographic Names Information System, National Hydrography Dataset, National Land Cover Database, National Structures Dataset, and National Transportation Dataset; U.S. Census Bureau - TIGER/Line; HERE Road Data

Figure 18.-Continued 


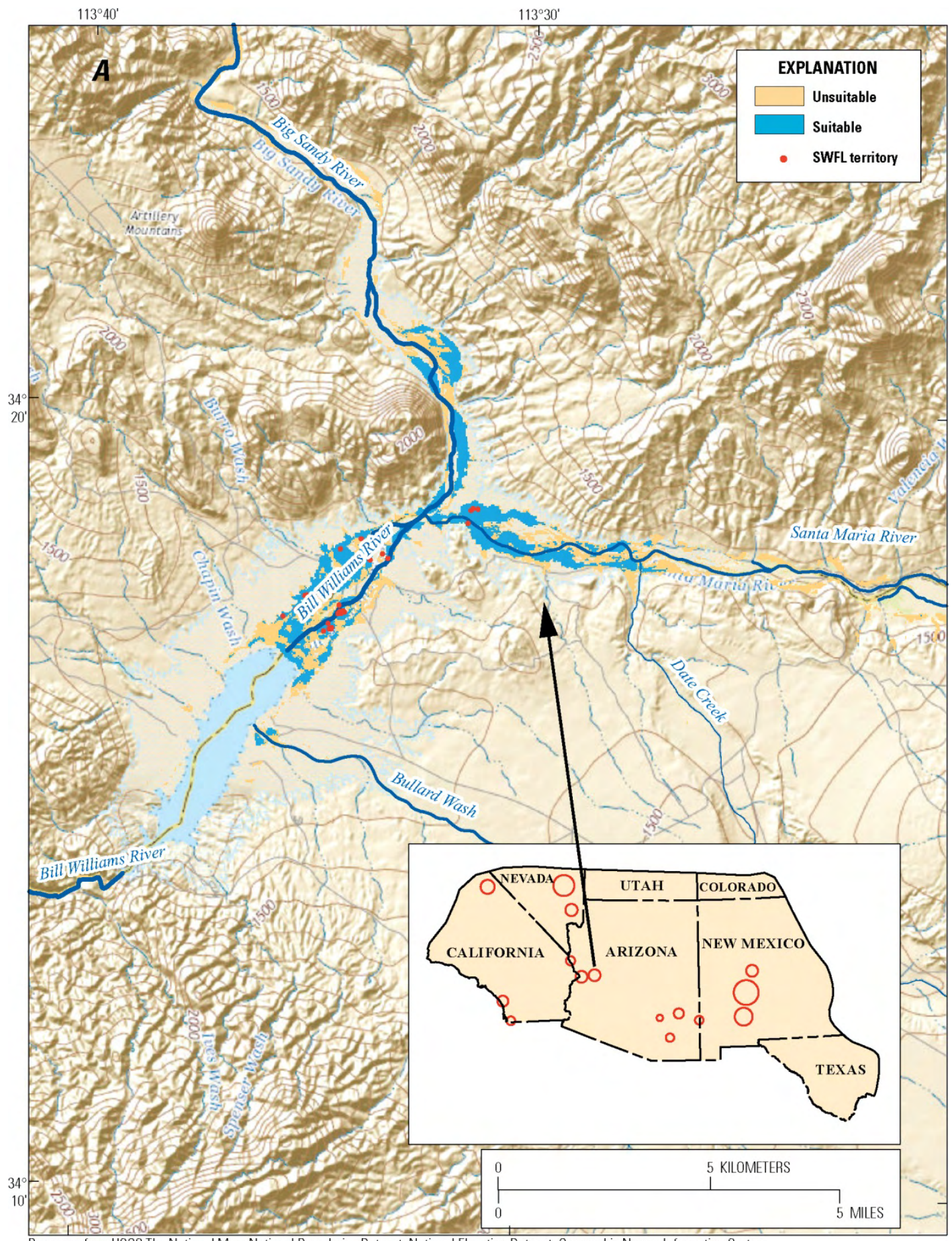

Base map from USGS The National Map: National Boundaries Dataset, National Elevation Dataset, Geographic Names Information System

National Hydrography Dataset, National Land Cover Database, National Structures Dataset, and National Transportation

Dataset; U.S. Census Bureau - TIGER/Line; HERE Road Data

Figure 19. Flycatcher habitat suitability maps of Alamo Lake, Arizona. (A) Produced by the satellite model at a 40percent probability threshold; cells with values greater than 40 percent are considered suitable and cells with values less than 40 percent are considered unsuitable. (B) Produced at 20-percent probability thresholds; probability class 1 is the lowest ranked habitat and class 5 is the highest. Southwestern Willow Flycatcher (SWFL) territories were located in summer 2014 by the Bureau of Reclamation. 


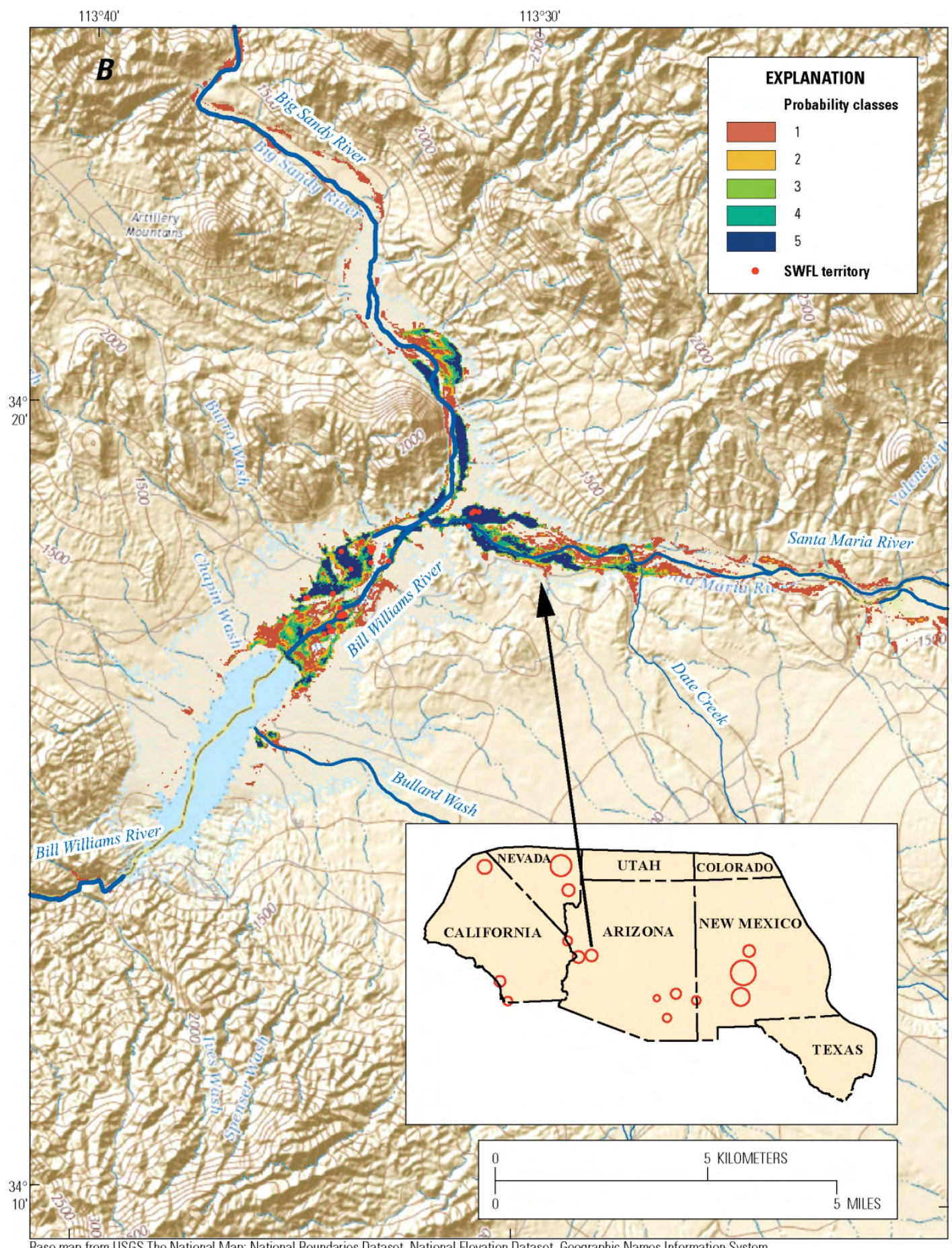

Base map from USGS The National Map: National Boundaries Dataset, National Elevation Dataset, Geographic Names Information System, National Hydrography Dataset, National Land Cover Database, National Structures Dataset, and National Transportation Dataset; U.S. Census Bureau - TIGER/Line; HERE Road Data

Figure 19.-Continued 


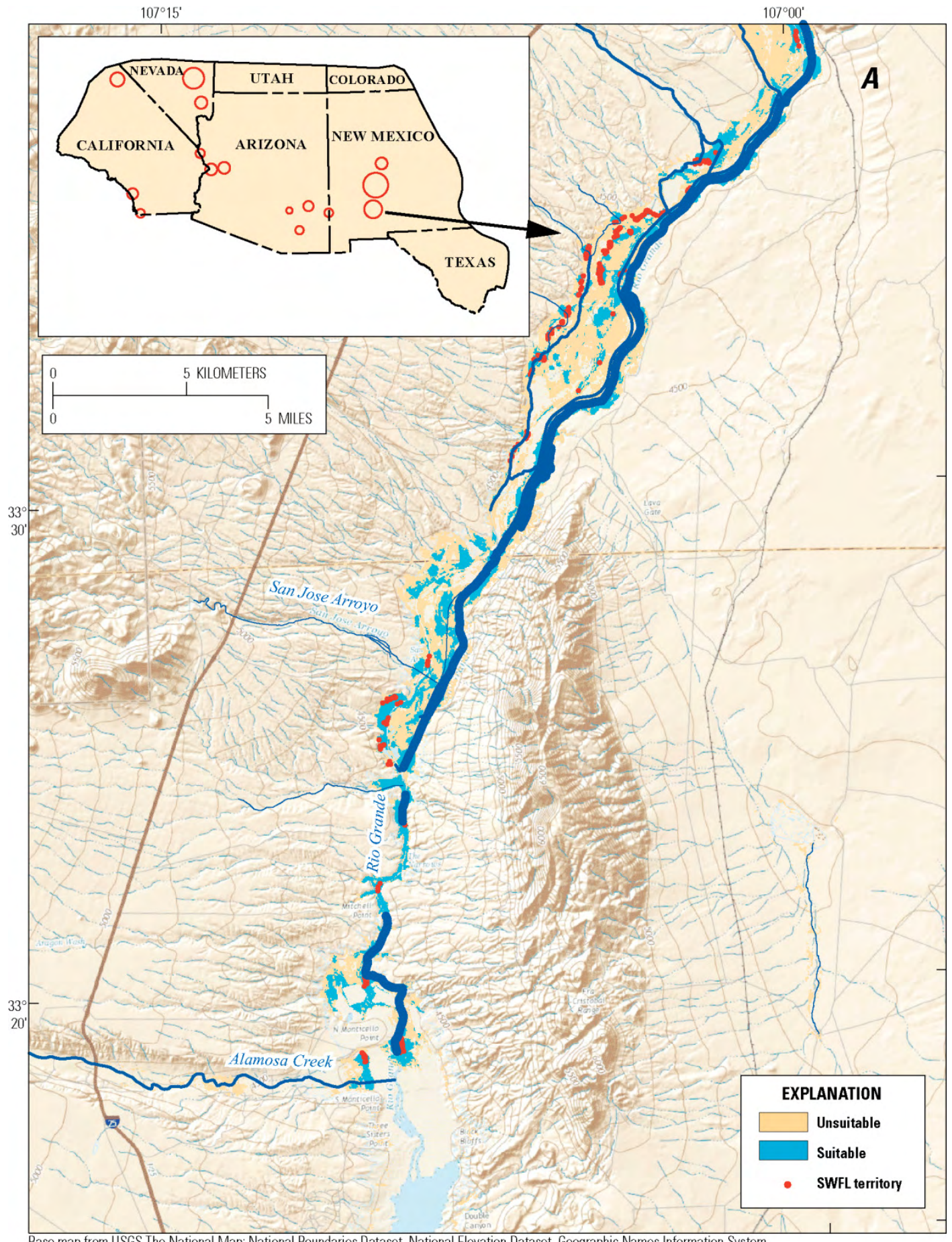

Base map from USGS The National Map: National Boundaries Dataset, National Elevation Dataset, Geographic Names Information System National Hydrography Dataset, National Land Cover Database, National Structures Dataset, and National Transportation Dataset; U.S. Census Bureau - TIGER/Line; HERE Road Data

Figure 20. Flycatcher habitat suitability maps of Rio Grande (Elephant Butte Reservoir), New Mexico. (A) Produced by the satellite model at a 40-percent probability threshold; cells with values greater than 40 percent are considered suitable and cells with values less than 40 percent are considered unsuitable. (B) Produced at 20percent probability thresholds; probability class 1 is the lowest ranked habitat and class 5 is the highest. Southwestern Willow Flycatcher (SWFL) territories were located in summer 2014 by the Bureau of Reclamation. 


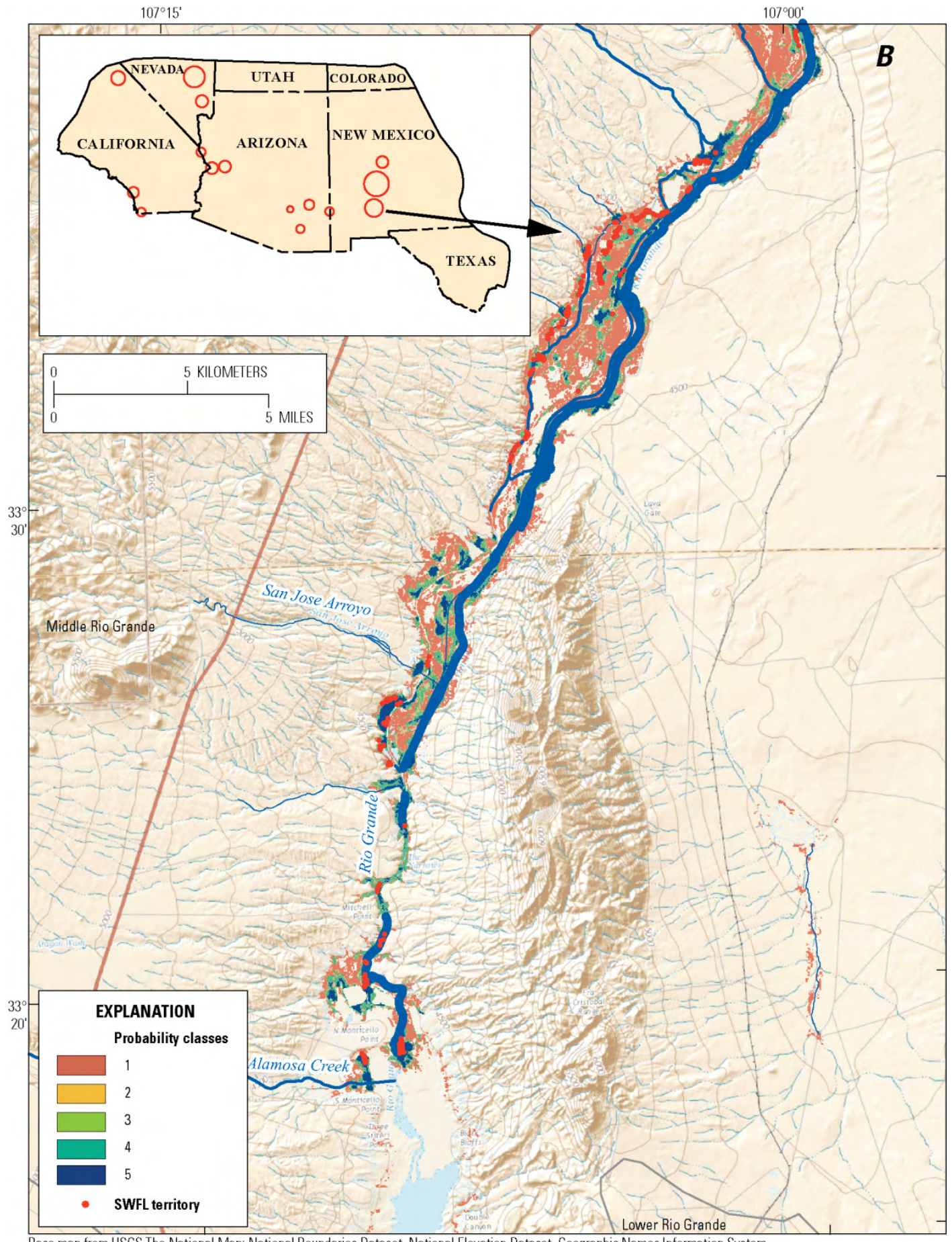

Base map from USGS The National Map: National Boundaries Dataset, National Elevation Dataset, Geographic Names Information System. National Hydrography Dataset, National Land Cover Database، National Structures Dataset, and National Transportation

Dataset; U.S. Census Bureau - TIGER/Line; HERE Road Data

Figure 20.-Continued 


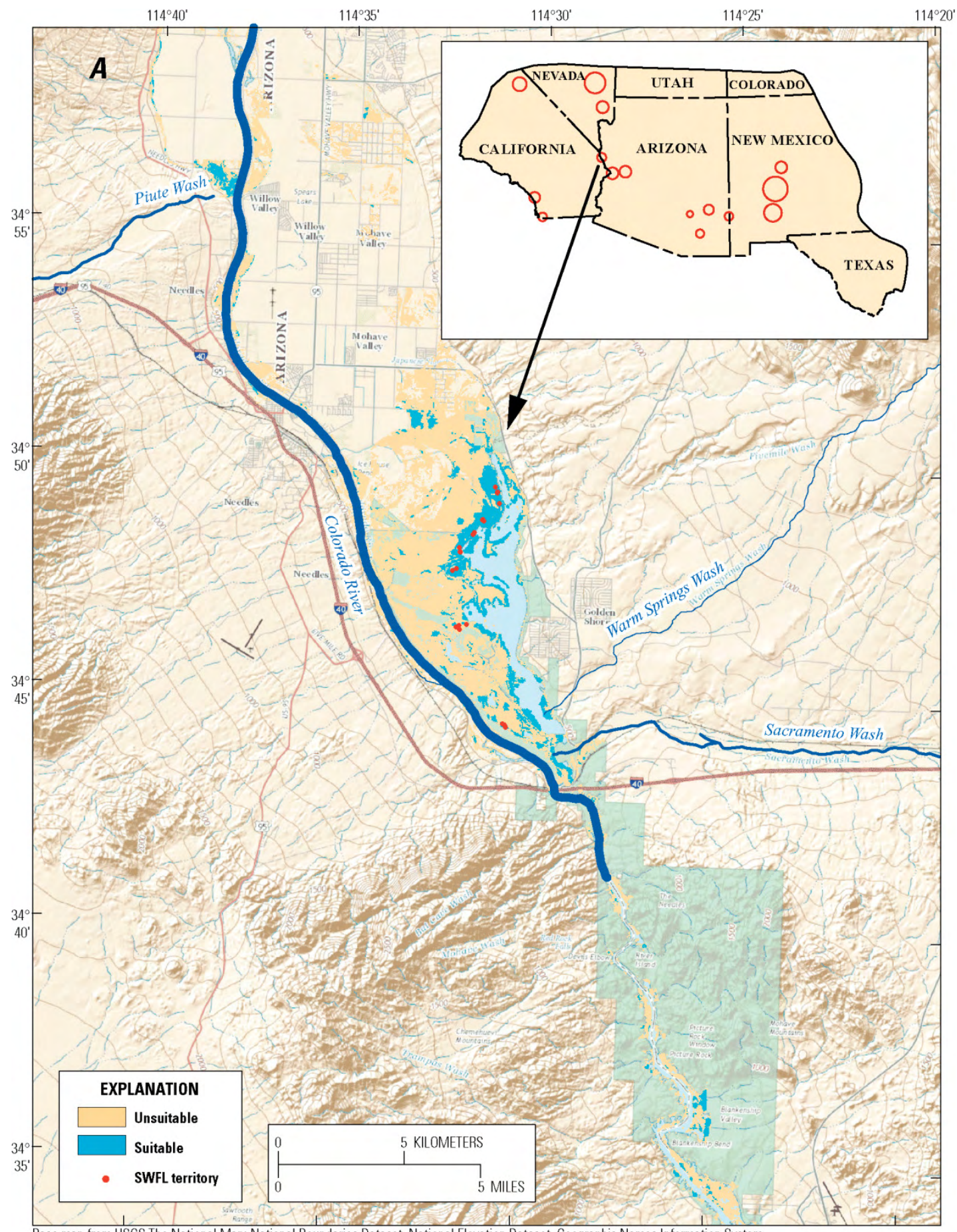

Base map from USGS The National Map: National Boundarles Dataset, National Elevation Dataset, Geographic Names Information System, National Hydrography Dataset, National Land Cover Database, National Structures Dataset, and National Transportation Dataset; U.S. Census Bureau - TIGER/Line; HERE Road Data

Figure 21. Fflycatcher habitat suitability maps of Havasu National Wildlife Refuge (Topock Marsh), Arizona and California. (A) Produced by the satellite model at a 40-percent probability threshold; cells with values greater than 40 percent are considered suitable and cells with values less than 40 percent are considered unsuitable. $(B)$ Produced at 20-percent probability thresholds; probability class 1 is the lowest ranked habitat and class 5 is the highest. Southwestern Willow Flycatcher (SWFL) territories were located in summer 2014 by the Bureau of Reclamation. 


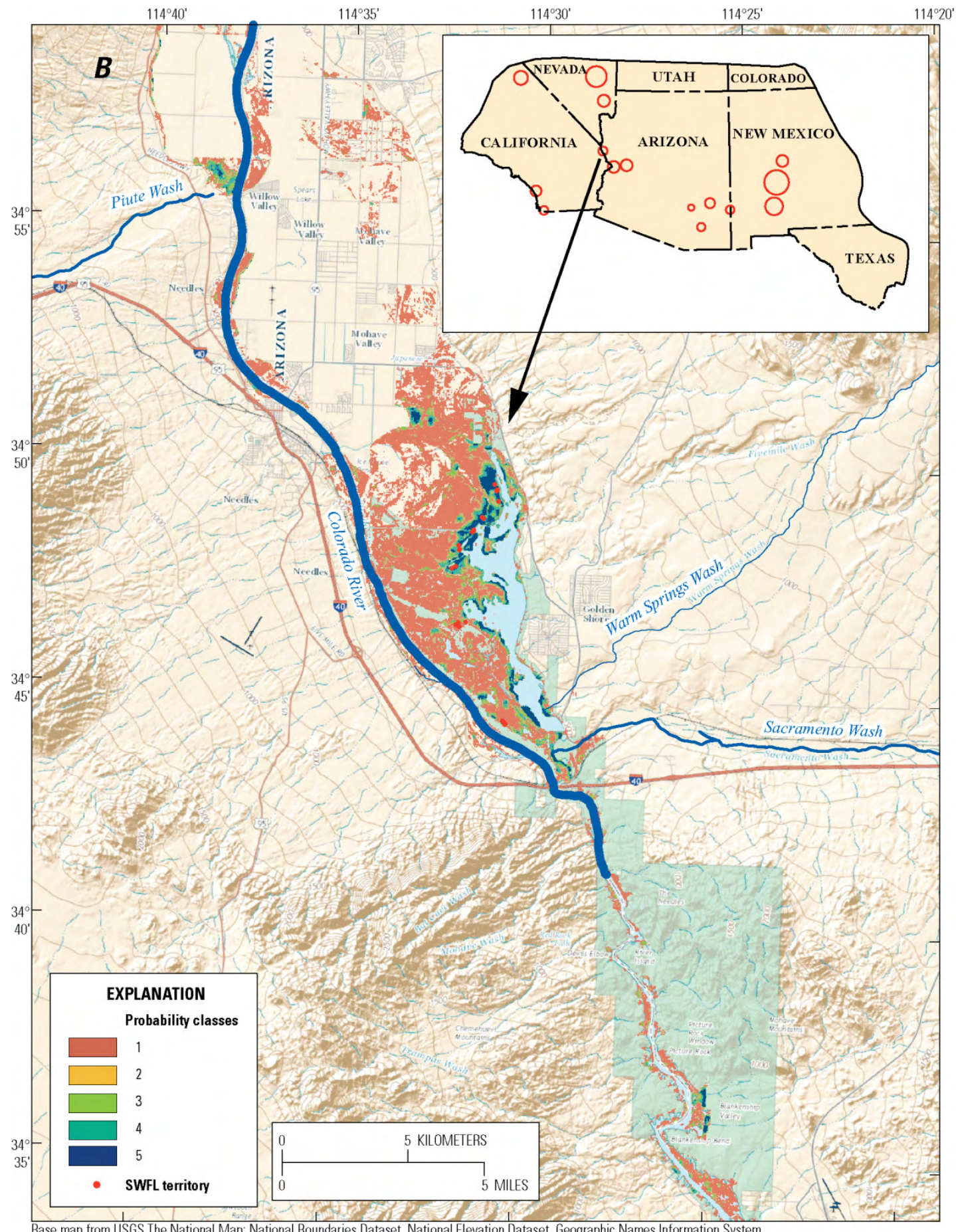

Base map from USGS The National Map: National Boundaries Dataset, National Elevation Dataset, Geographic Names Information System, National Hydrography Dataset, National Land Cover Database, National Structures Dataset, and National Transportation Dataset; U.S. Census Bureau - TIGER/Line; HERE Road Data

Figure 21.-Continued 


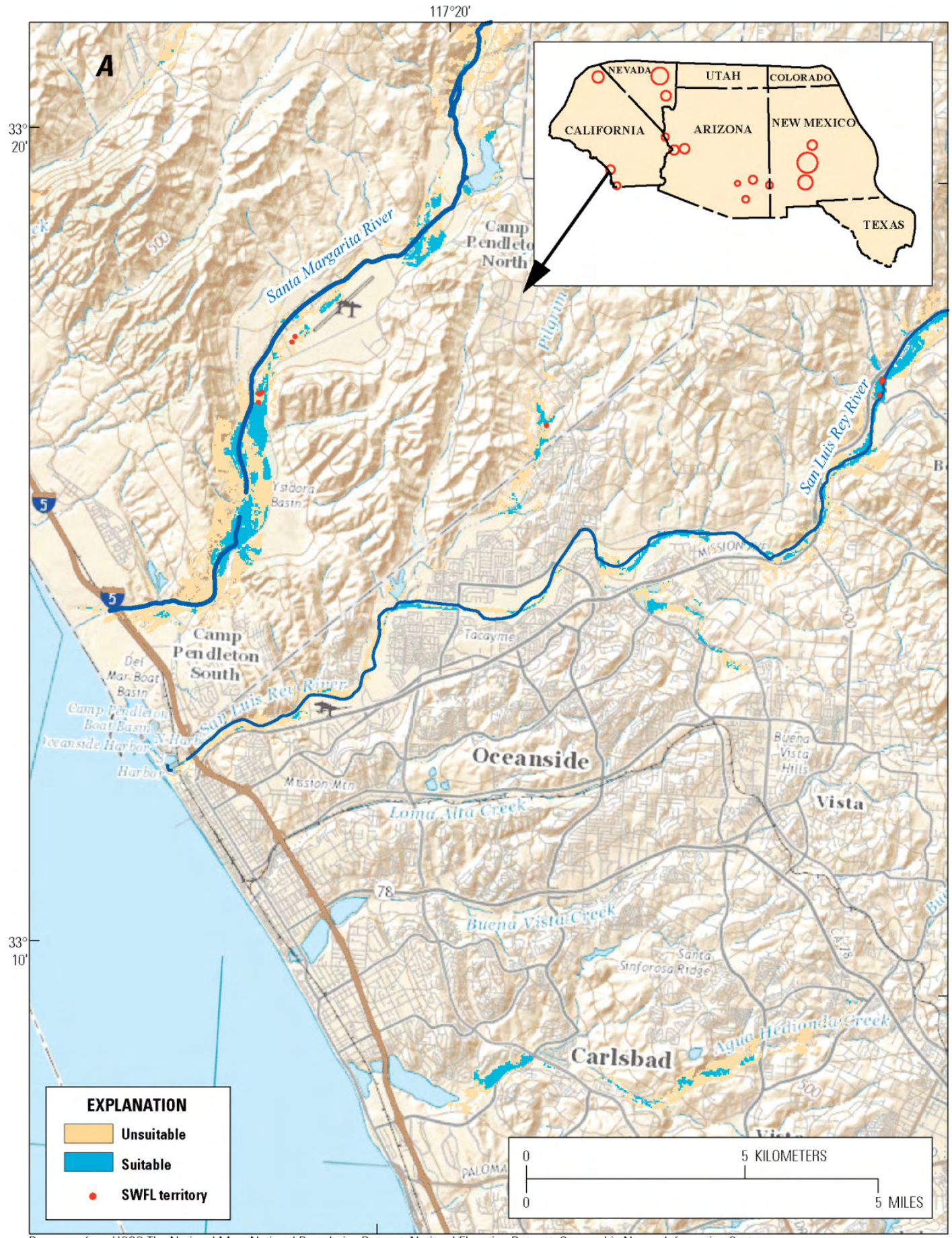

Base map from USGS The National Map: National Boundaries Dataset, National Elevation Dataset, Geographic Names Information System, National Hydrography Dataset, National Land Cover Database, National Structures Dataset, and National Transportation Dataset; U.S. Census Bureau - TIGER/Line; HERE Road Data

Figure 22. Flycatcher habitat suitability maps of the Santa Margarita and San Luis Rey Rivers (Camp Pendleton), California. (A) Produced by the satellite model at a 40-percent probability threshold; cells with values greater than 40 percent are considered suitable and cells with values less than 40 percent are considered unsuitable. $(B)$ Produced at 20-percent probability thresholds; probability class 1 is the lowest ranked habitat and class 5 is the highest. Southwestern Willow Flycatcher (SWFL) territories were located in summer 2014 by the U.S. Geological Survey. 


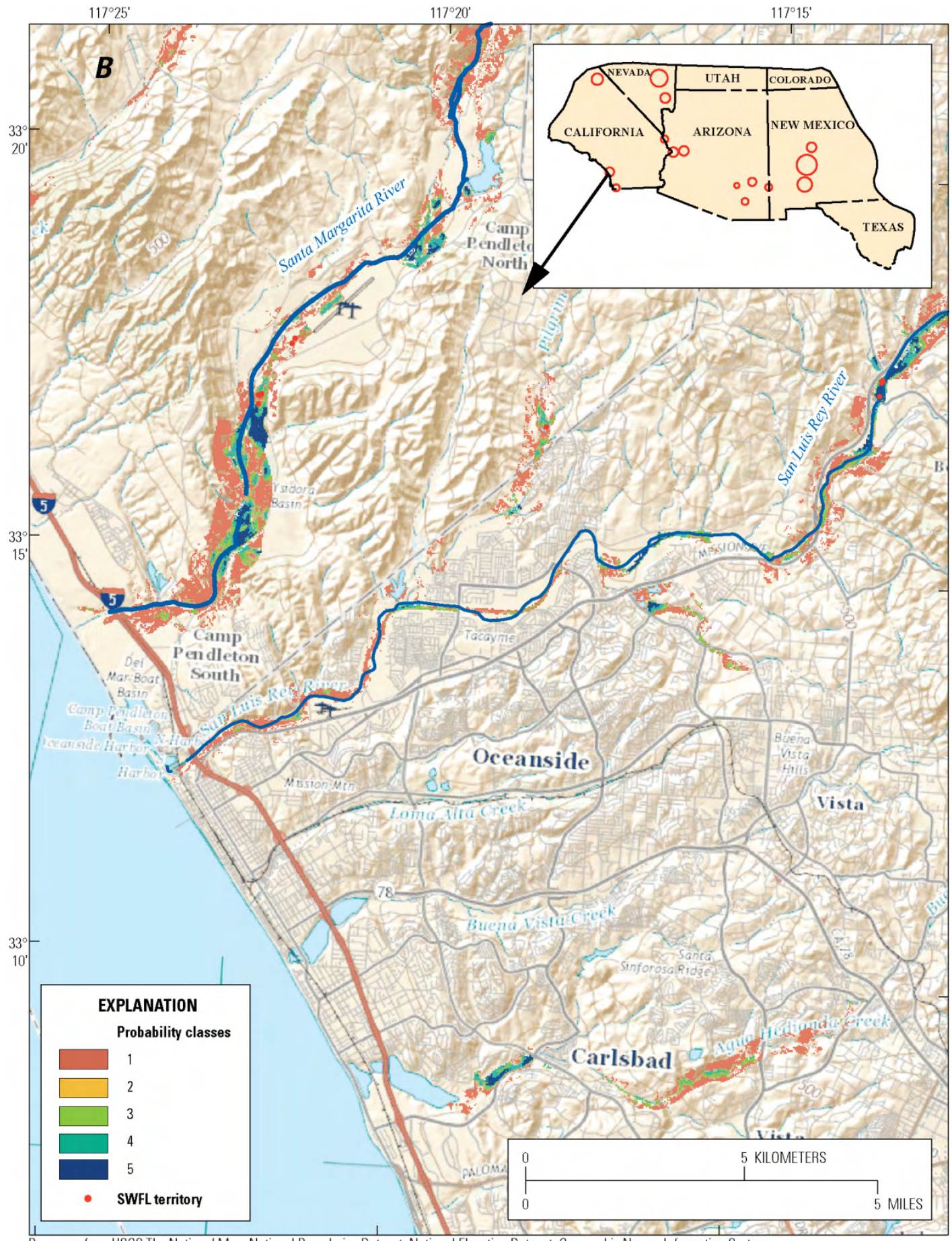

Base map from USGS The National Map: National Boundaries Dataset, National Elevation Dataset, Geographic Names Information System. National Hydrography Dataset, National Land Cover Database, National Structures Dataset, and National Transportation Dataset; U.S. Census Bureau - TIGER/Line; HERE Road Data

Figure 22.-Continued 
Omission errors were acceptable in all areas examined, without any identified performance issues by geographic area, but commission errors were high wherever the model was applied. Commission errors are locations $(30 \times 30$-m cells $)$ determined through the model to be suitable but that did not contain a flycatcher territory (Story and Congalton, 1986). Unlike omission errors, which really are classification errors, commission errors do not provide proof that the model is wrong because a location may actually be suitable but not contain a flycatcher territory. Given the scarcity of flycatchers throughout their range, it is not surprising that many locations considered suitable by the model were empty. The reader may find a more detailed discussion related to model accuracy in section, "Discussion."

\section{Habitat Change Detection}

Predicted flycatcher habitat changed directionally from 2013 to 2015, with habitat generally increasing eastwards and decreasing westwards (fig. 23). Specifically, predicted habitat increased substantially in New Mexico and Texas; Arizona, Utah, and Nevada were mixed (both increases and decreases); and California was largely decreases. Habitat increases outnumbered decreases, with 68 percent of the top-ranking quadrangles increased and 32 percent decreased. The top-ranking quadrangles were in Texas (48 percent), followed by New Mexico (36 percent), Arizona (14 percent), and California ( 2 percent). In contrast, the 50 quadrangles with the largest decreases in predicted habitat were in California (56 percent), Arizona (32 percent), Nevada (8 percent), and New Mexico (4 percent). Change in predicted flycatcher habitat was greatest at Lake Mcmillan, Texas, from June 2014 to June 2015, increasing by 132 percent in the Lake Mcmillan North quadrangle, and 143 percent in the Spring Lake quadrangle (fig. 24). The second largest changes were observed near Fort Craig and San Marcial, New Mexico, where predicted habitat increased 177 percent in the Fort Craig quadrangle and 98 percent in the San Marcial quadrangle (fig. 25). 


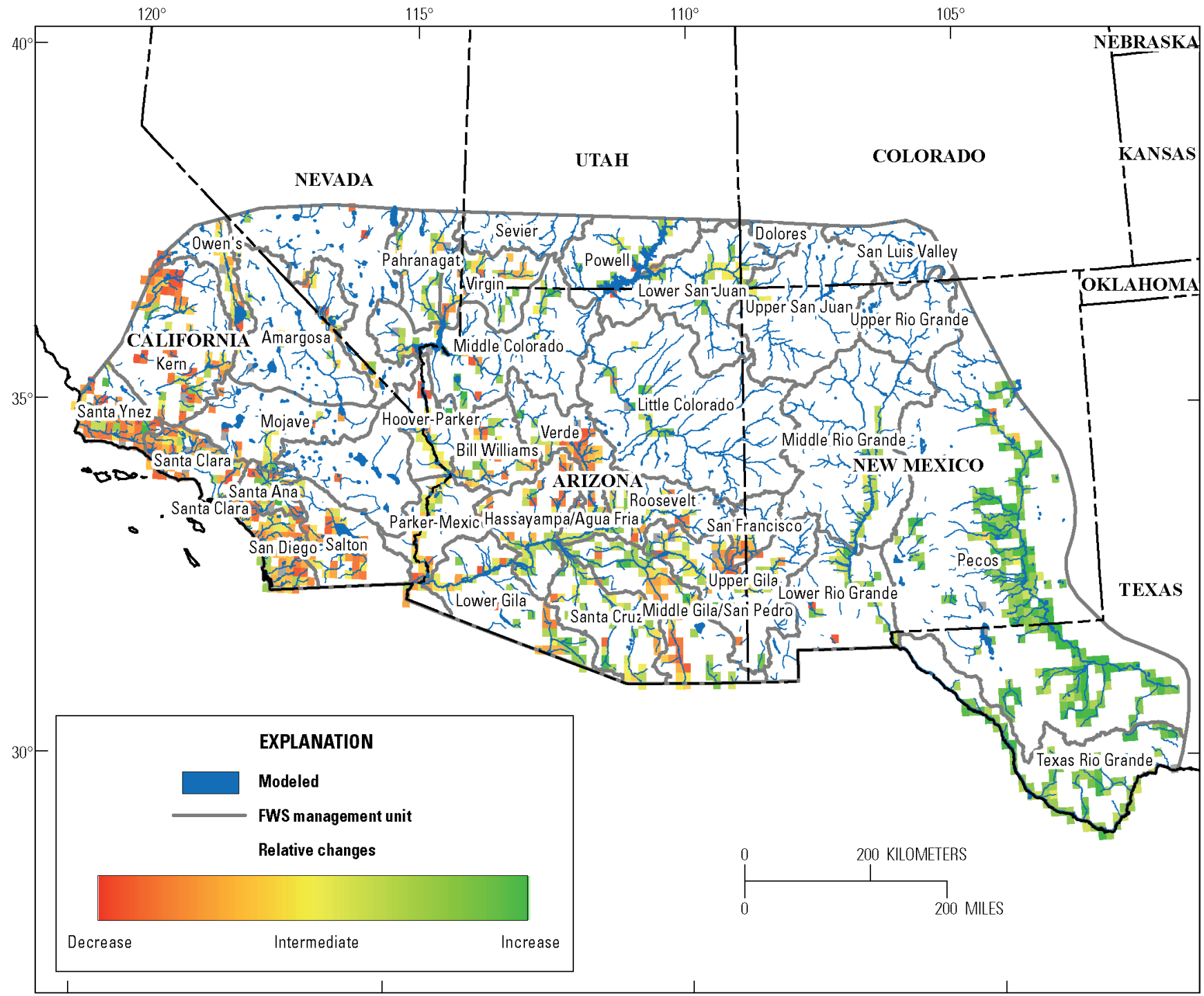

Figure 23. Map showing relative changes in predicted flycatcher habitat, as determined from a satellite model at a 40-percent probability threshold, Southwestern United States, 2013-15. 


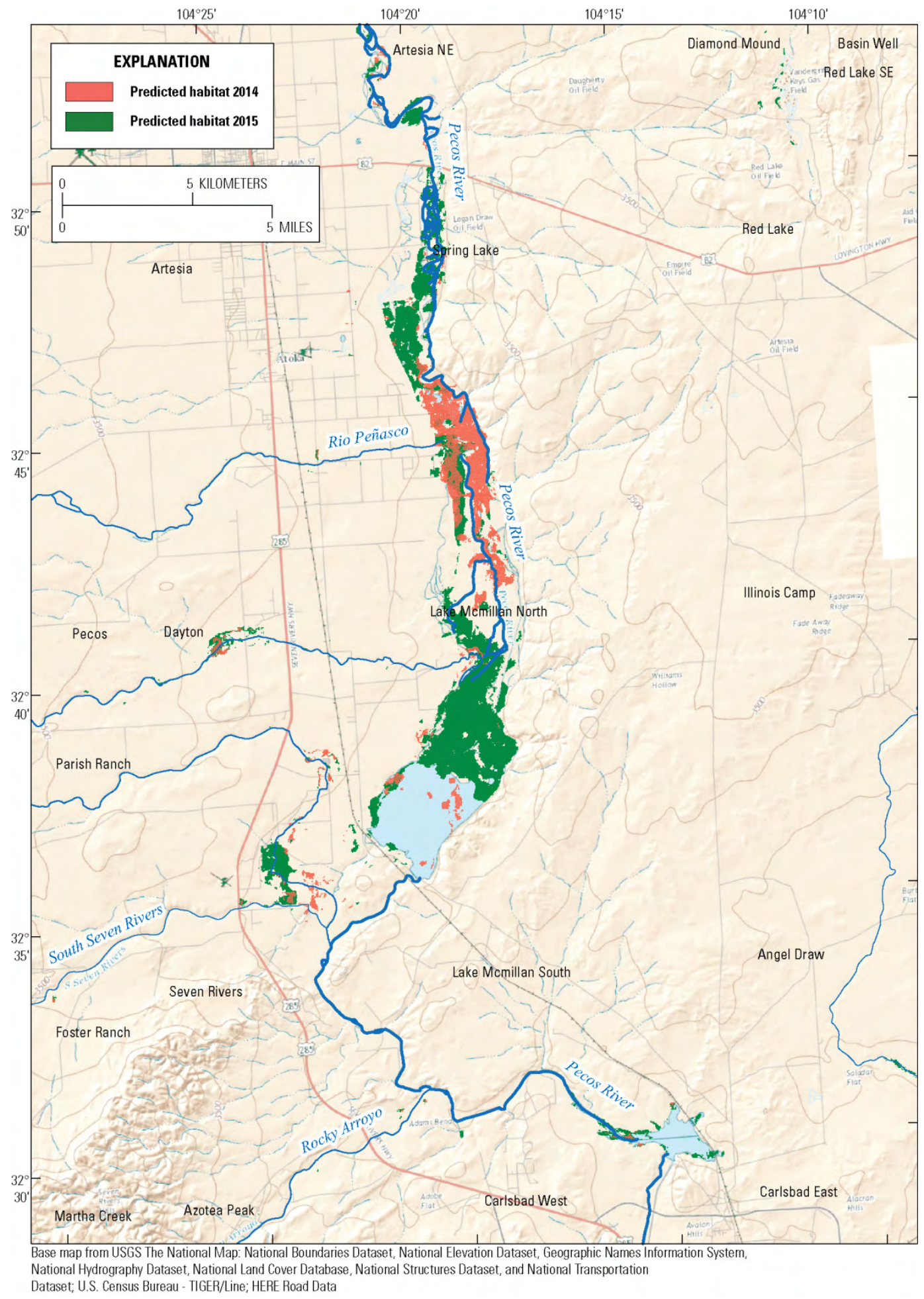

Figure 24. Map showing changes in predicted flycatcher habitat at Lake McMillan, Texas, June 2014-June 2015. Predicted habitat in 2014 completely overlays 2015 predicted habitat, which produces a hybrid color (brown). Predicted habitat increased 132 percent in the Lake McMillan North quadrangle, and 143 percent in the Spring Lake quadrangle. 


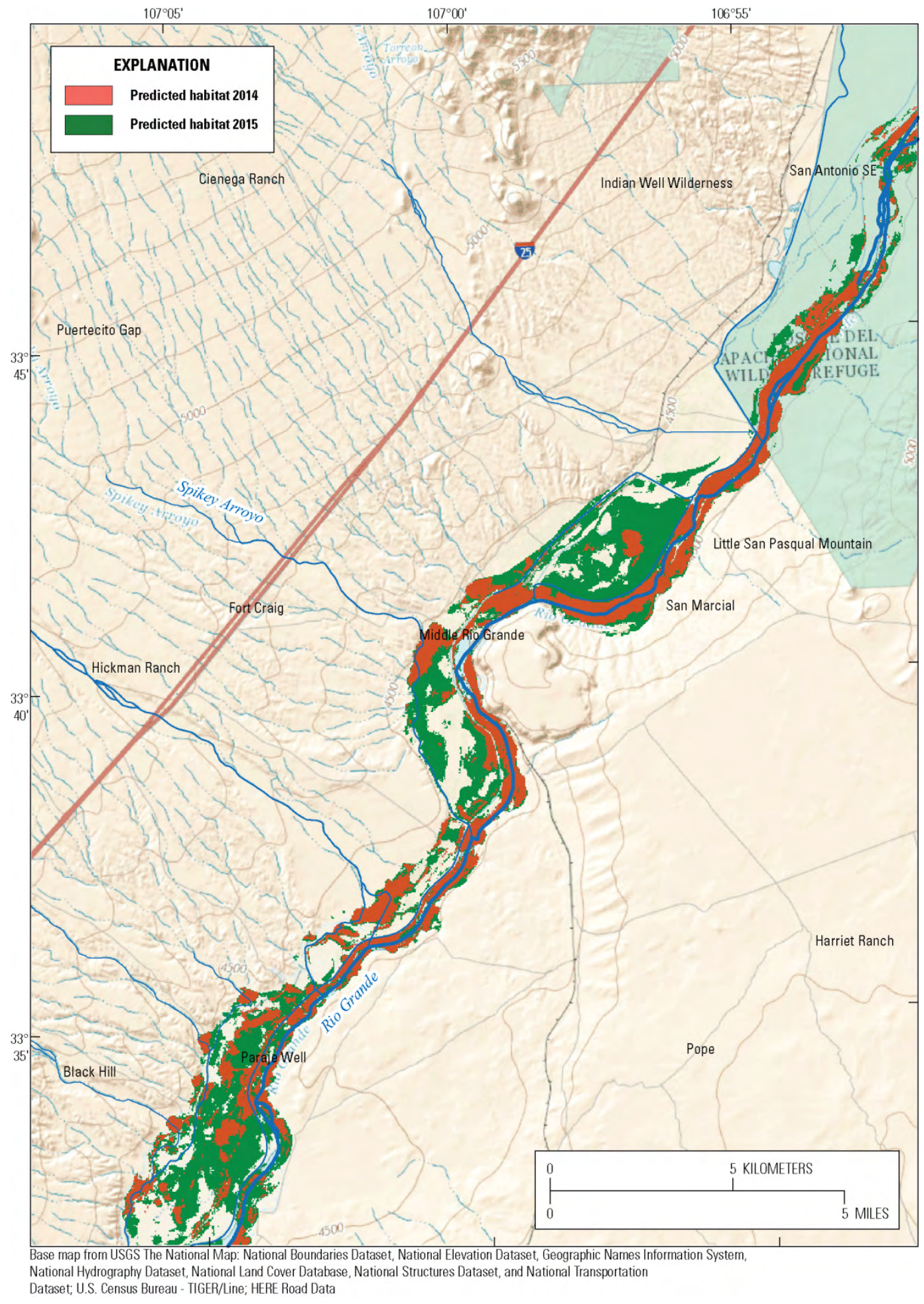

Figure 25. Map showing changes in predicted flycatcher habitat in Fort Craig and San Marcial quadrangles, New Mexico, 2014-15. Predicted habitat in 2014 completely overlays 2015 predicted habitat, which produces a hybrid color (brown). Predicted habitat increased 177 percent in the Fort Craig quadrangle and 98 percent in the San Marcial quadrangle between years. 


\section{Tamarisk Leaf Beetle Impact Assessment}

\section{Lower Virgin River}

The Virgin River habitat time series produced a cyclical pattern in predicted flycatcher habitat from 1986 to 2015 (fig. 26), with a yearly average of 700.3 ha and a standard deviation of 175.6 ha (95percent CI [ 356 ha, 1,044 ha]). When calculating the historical average, I did not include habitat for 2013-15 because it was well outside the 95-percent CIs observed from 1986 to 2012. Given this large deviation, which was clearly the result of beetles, I compared the last years (2013-15) to the historical average (1986 and 2012). Although the overall pattern from 1986 to 2015 was variable, a clear pattern of habitat formation, persistence, and decreases were evident. For descriptive purposes, the time series was divided into five distinct periods characterized by low, moderate, and high habitat production. Specifically, the period from 1986 to 1994 produced moderate amounts of habitat (503 and 710 ha), with the exception of 1992, which only produced 355 ha. The period from 1995 to 2001 was the most robust period of habitat production, when 3 of the top 5 years exceeded 900 ha. The period from 2002 to 2007 was another moderate period, producing from 540 to 749 ha per year. The years $2008-2010$ were another robust period, producing from 867 to 987 ha per year, with 2 of the top 5 years (912 and 937 ha). The year 2011 was a transition year that separated a robust period (2008-2010) from an exceptionally poor period. Specifically, habitat was less than 100 ha per year $(\bar{Y}=88$ ha) for $2013-15$, falling well short of the lower 95-percent CI (356 ha), with just 12.6 percent of the historical average (3.5 standard deviations).

Comparing the years 2010 and 2015, which are pre- and post-beetle years, respectively, there were 937 ha of predicted habitat in 2010, and 87 ha in 2015, representing a 90.7 percent loss (fig. 27). Decomposed further, 94.19 percent of predicted habitat was lost, 5.81 percent persisted, and there was a 3.53 percent gain in new habitat (fig. 28). The NDVI values decreased by 48.9 percent where predicted flycatcher habitat was lost, and by 9.5 percent where habitat persisted (fig. 29). In areas that were predicted to be unsuitable both in 2010 and 2015, NDVI values actually increased by 6.7 percent. Finally, in regions that became suitable in 2015, NDVI values increased by 101.1 percent. Dividing the channel into seven change zones (fig. 30), zones 1-6 lost from 28.7 to 100.0 percent of predicted habitat, whereas zone 7 showed an increase of 160.0 percent (table 4). Predicted habitat was not evenly distributed in these zones, making the impacts disproportionate. For example, zone 1 (Lake Mead National Recreation Area boundary to Halfway Wash) had 618.3 ha of predicted habitat in 2010, which is over five times more than any other zone, and it lost 99.6 percent of its habitat. In contrast, zone 7

(Beaver Dam Wash to the Narrows) had only 0.5 ha of predicted habitat in 2010 and 1.2 ha of predicted habitat in 2015, marking a 140 percent increase, but it only amounted to 0.8 ha. 
Table 4. Area of predicted flycatcher habitat before and after tamarisk leaf beetle-impact analysis was done for the lower Virgin River, Nevada and Arizona, 2010 and 2015.

[The satellite model produced the habitat estimates at a 40-percent probability threshold. Zone: There are seven lower Virgin River zones, as shown in figure 27. Habitat_pre: Flycatcher habitat before leaf beetle-impact analysis was done.

Habitat_post: Flycatcher habitat after leaf beetle-impact analysis was done. Change: Changes in predicted flycatcher habitat from 2010 (pre-beetle) to 2015 (post-beetle). NHDPlus tributary junctions: The seven zones are delineated by tributary junctions available in the U.S. Geological Survey NHDPlus dataset]

\begin{tabular}{|c|c|c|c|c|}
\hline \multirow{2}{*}{ Zone } & \multicolumn{2}{|c|}{ Habitat area (hectares) } & \multirow{2}{*}{$\begin{array}{l}\text { Change } \\
\text { (percent) }\end{array}$} & \multirow{2}{*}{ NHDPlus tributary junctions } \\
\hline & Habitat_pre & Habitat_post & & \\
\hline 1 & 618.3 & 2.6 & -99.6 & $\begin{array}{l}\text { Lake Mead National Recreation Area boundary to } \\
\text { Halfway Wash }\end{array}$ \\
\hline 2 & 51.9 & 8.4 & -83.9 & Halfway Wash to Nickel Creek \\
\hline 3 & 13.1 & 0.0 & -100.0 & Nickel Creek to Toquop Wash \\
\hline 4 & 100.7 & 42.8 & -57.6 & Toquop Wash to Pulsipher Wash \\
\hline 5 & 116.5 & 6.4 & -94.5 & Pulsipher Wash to Sand Hollow Wash \\
\hline 6 & 36.7 & 26.2 & -28.7 & Sand Hollow Wash to Beaver Dam Wash \\
\hline 7 & 0.5 & 1.2 & 160.0 & $\begin{array}{l}\text { Beaver Dam Wash to the Narrows (about } 8 \text { kilometers } \\
\text { upstream of Beaver Dam Wash) }\end{array}$ \\
\hline
\end{tabular}




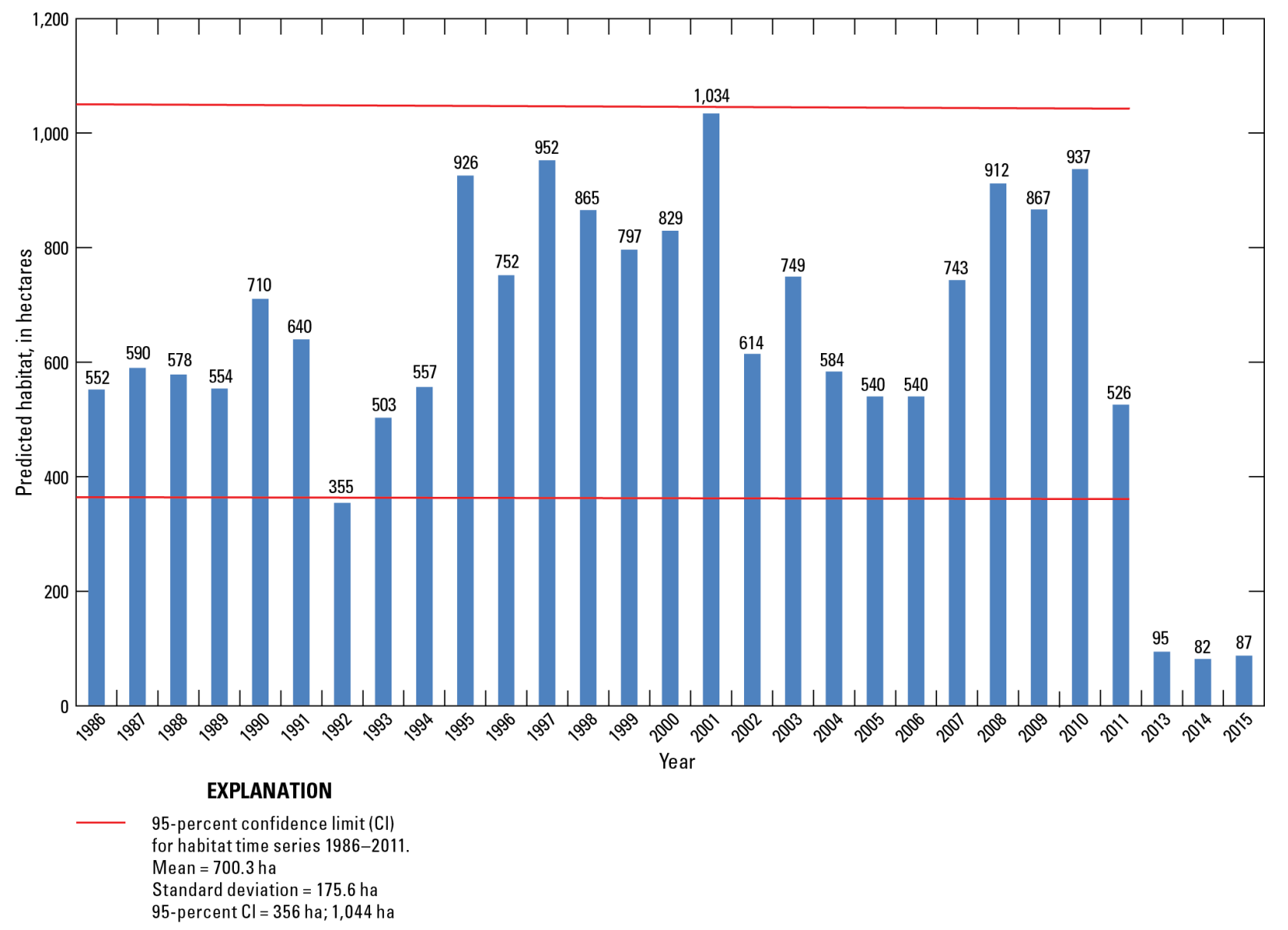

Figure 26. A habitat time series of the lower Virgin River (see fig. 8), Nevada and Arizona, produced by running the satellite model repeatedly from 1986 to 2015 (2012 omitted). Mean value for 2013-15 was 88 ha, or 12.6 percent of historical average (1986-2011). See table A4 for image acquisition dates for each year. 


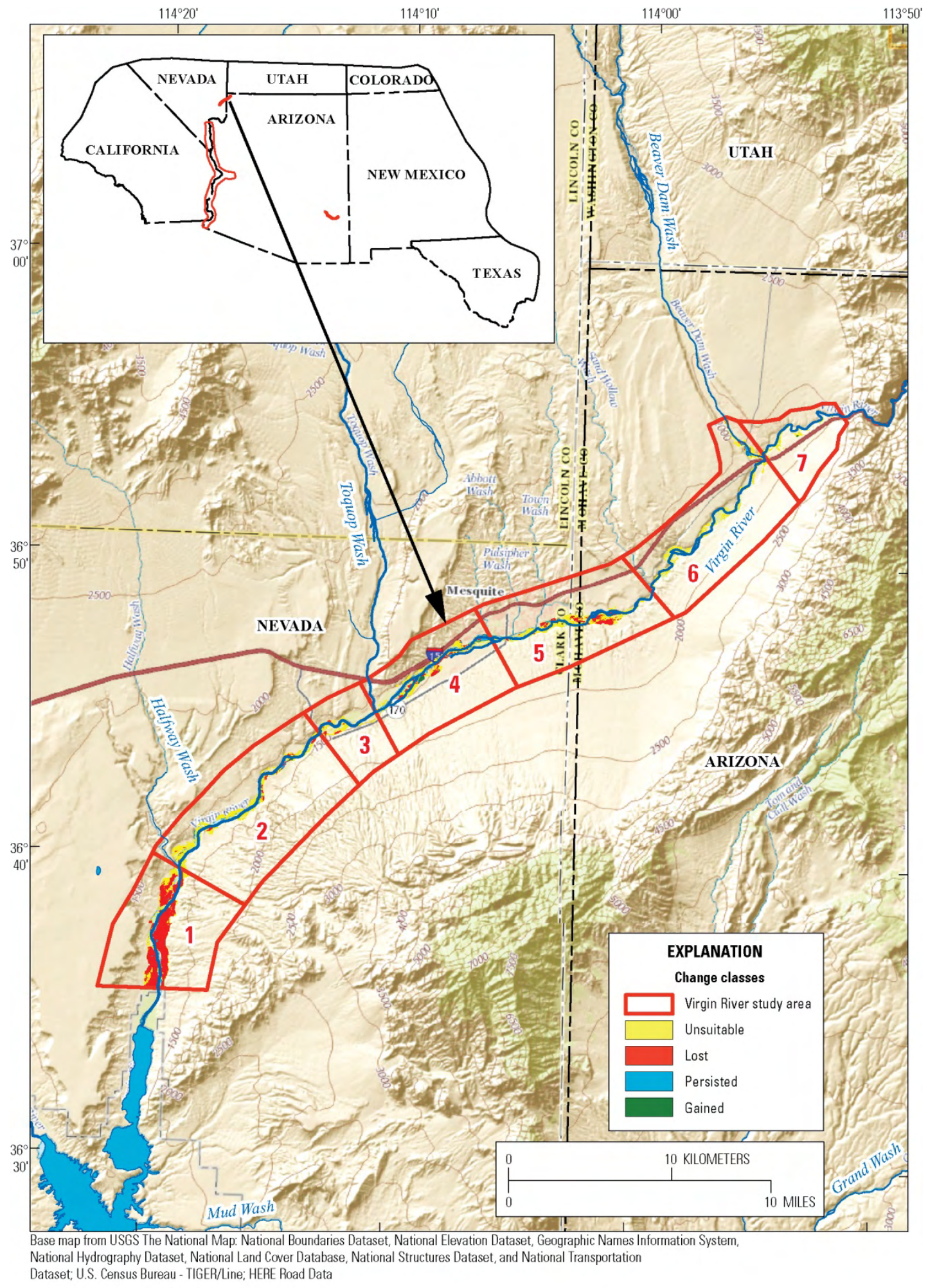

Figure 27. Map showing changes in predicted flycatcher habitat along the lower Virgin River, Nevada and Arizona, 2010-2015, as determined from a satellite model at a 40-percent probability threshold. 


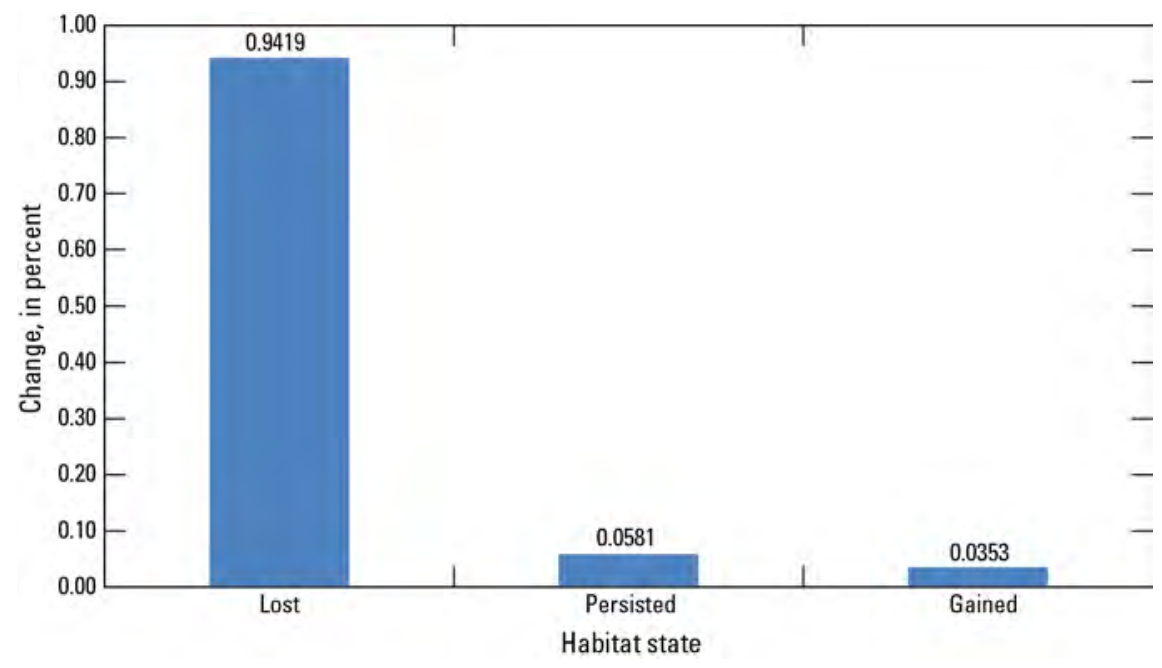

Figure 28. Graph showing changes in area of predicted flycatcher habitat in the lower Virgin River, Nevada and Arizona (fig. 27), 2010-2015. Specifically, 94.19 percent of habitat was lost, 5.81 percent persisted, and 3.53 percent of new habitat was gained. Satellite model was used to predict flycatcher habitat at a 40-percent probability threshold.

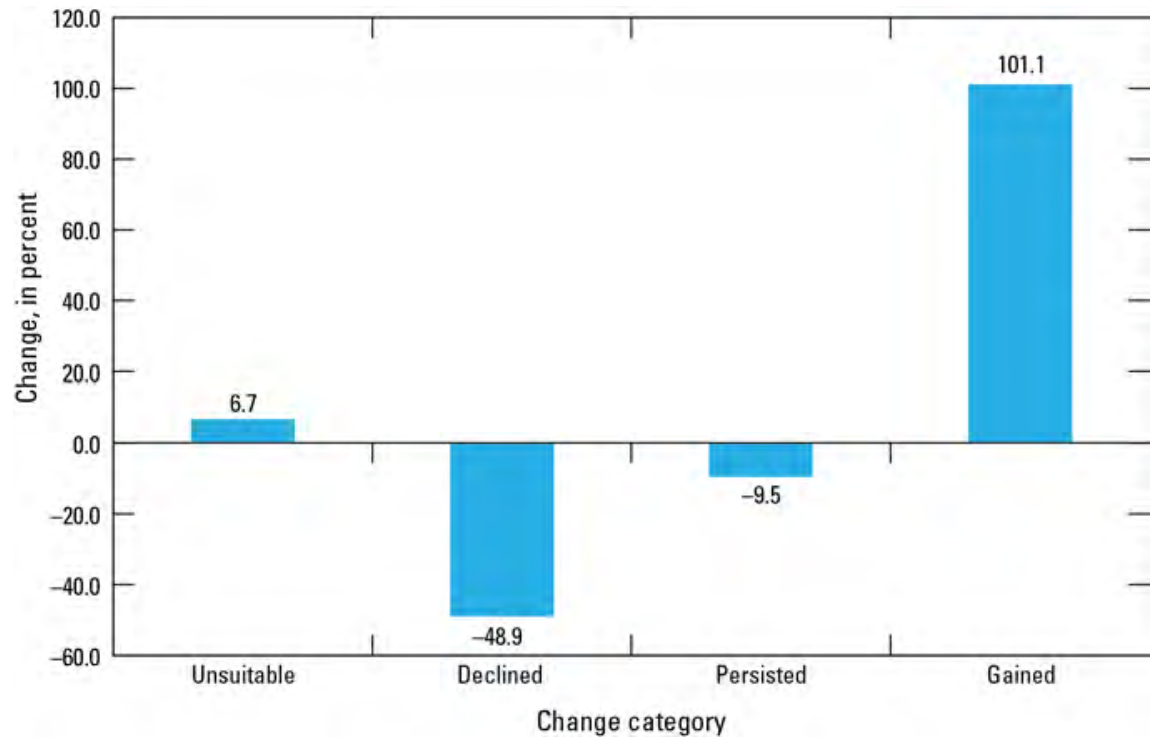

Figure 29. Graph showing changes in NDVI values in four zones from 2010 (June 22) to 2015 (June 25-) in the lower Virgin River, Nevada and Arizona. Unsuitable (was not suitable flycatcher habitat in 2010 or 2015); Declined (flycatcher habitat was lost); Persisted (habitat persisted); and Gained (habitat formed). Thus, NDVI values declined 48.9 percent in areas where flycatcher habitat was lost (Declined) from 2010 to 2015, while NDVI increased 101.1 percent in locations where flycatcher habitat formed. 


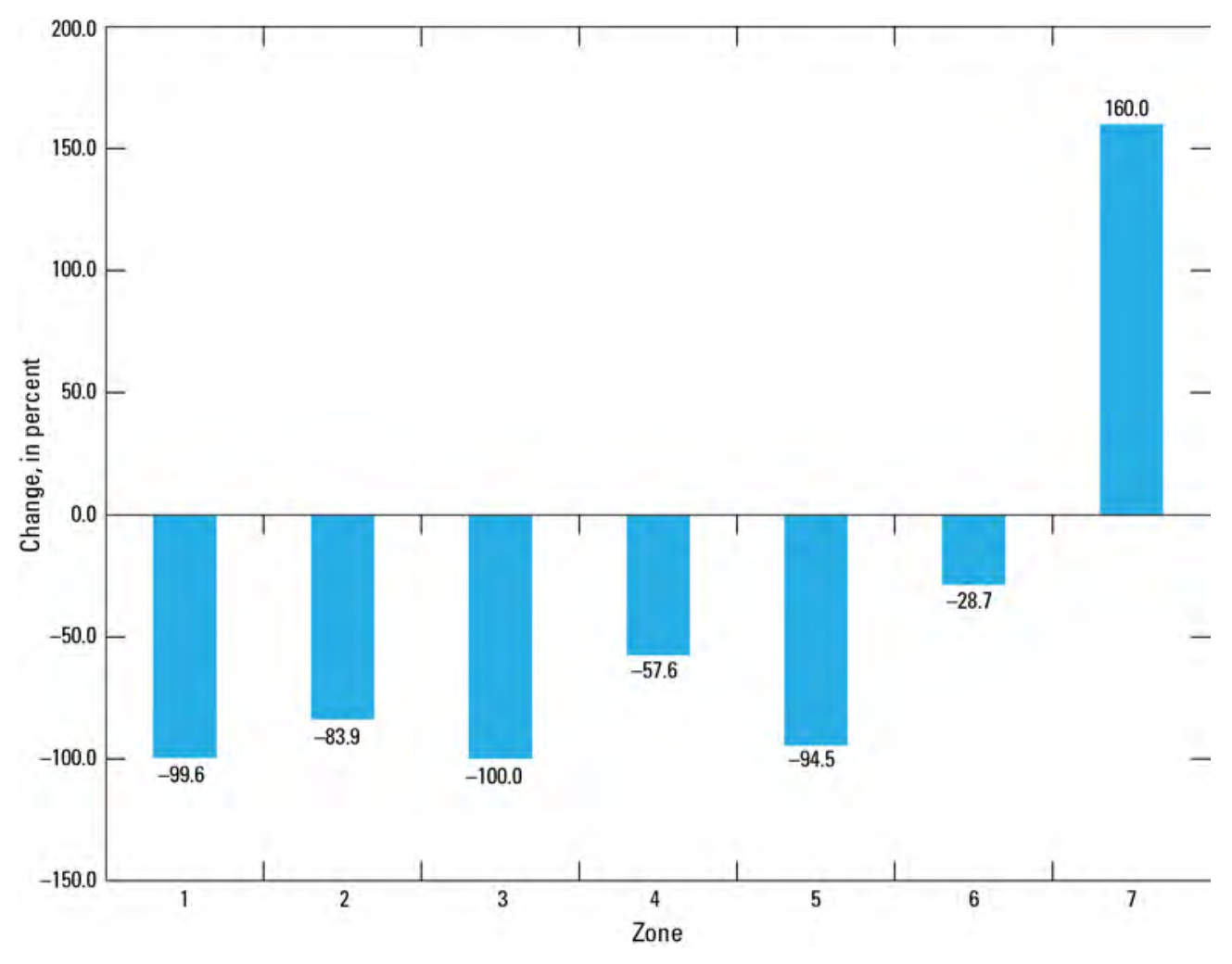

Figure 30. Graph showing changes in predicted flycatcher habitat inside seven zones (fig. 27) along the lower Virgin River, Nevada and Arizona, 2010-2015. A satellite model was used to predict flycatcher habitat at a 40percent probability threshold.

\section{Lower Colorado River}

A beetle-impact simulation for the lower $549 \mathrm{~km}$ of the Colorado River resulted in a 33.5percent decrease in predicted flycatcher habitat (table 5), with 4,658 ha of predicted flycatcher habitat before the simulation and 3,099 ha afterwards. The Lower Colorado River reach was too large to show simulated changes efficiently, so close ups were provided of Topock Marsh (fig. 31) and Cibola National Wildlife Refuge (fig. 32). A close examination of flycatcher territories at Topock Marsh in 2014 indicated that 79 percent of the territories occurred in habitat that is predicted to persist should beetles arrive, whereas 10.3 percent occurred in habitat predicted to be lost. The remaining three territories were not found in predicted habitat and are thus classified as omission error. The four Reclamation conservation areas did not have much predicted flycatcher habitat in 2015 , so the beetleimpact simulation also resulted in small changes in these areas. In contrast, the Cibola National Wildlife Refuge showed much more promising results in the Reclamation conservation zones, with a substantial amount of predicted flycatcher habitat persisting after the beetle-impact simulation in numerous units. 
Table 5. Changes in predicted Southwestern Willow Flycatcher habitat along lower Colorado River, California, Nevada, and Arizona, after a beetle-impact simulation was done in 2015.

[The satellite model produced the habitat estimates at a 40-percent probability threshold. Management Unit: Amount of predicted flycatcher habitat is divided into U.S. Fish and Wildlife Service flycatcher management units (see fig. 9).

Pre_beetle is predicted flycatcher habitat (hectares) before a leaf beetle-impact simulation was done; Post_beetle is predicted flycatcher habitat (hectares) after a leaf beetle-impact simulation was done]

\begin{tabular}{lccc}
\hline \multirow{2}{*}{ Management unit } & \multicolumn{2}{c}{ Habitat area (hectares) } & \multirow{2}{*}{$\begin{array}{c}\text { Change } \\
\text { (percent) }\end{array}$} \\
\cline { 2 - 3 } & Pre_beetle & Post_beetle & -46.7 \\
\hline Lower Gila & 69 & 37 & -36.4 \\
Parker-Mexico & 2,899 & 1,843 & -8.5 \\
Bill Williams & 557 & 510 & -37.3 \\
Hoover-Parker & 1,133 & 710 & -33.5 \\
Total & 4,658 & 3,099 & \\
\hline
\end{tabular}

Divided into three distinct habitat states, the beetle-impact simulation along the Lower Colorado River resulted in 2.4 percent new habitat (113.5 ha), 35.9 percent lost habitat (1,672 ha), and 64.1 percent (2,986 ha) habitat that persisted (fig. 33). The Lower Gila FWS flycatcher management unit (fig. 9) is predicted to lose 46.7 percent habitat, Parker-Mexico to lose 36.4 percent, Bill Williams to lose 8.5 percent, and Hoover-Parker to lose 37.3 percent (fig. 34). The magnitude of loss indicates the proportion of tamarisk that comprised (overlapped) predicted flycatcher habitat, with the Bill Williams having the least amount of overlap and the Lower Gila having the most amount of overlap. 


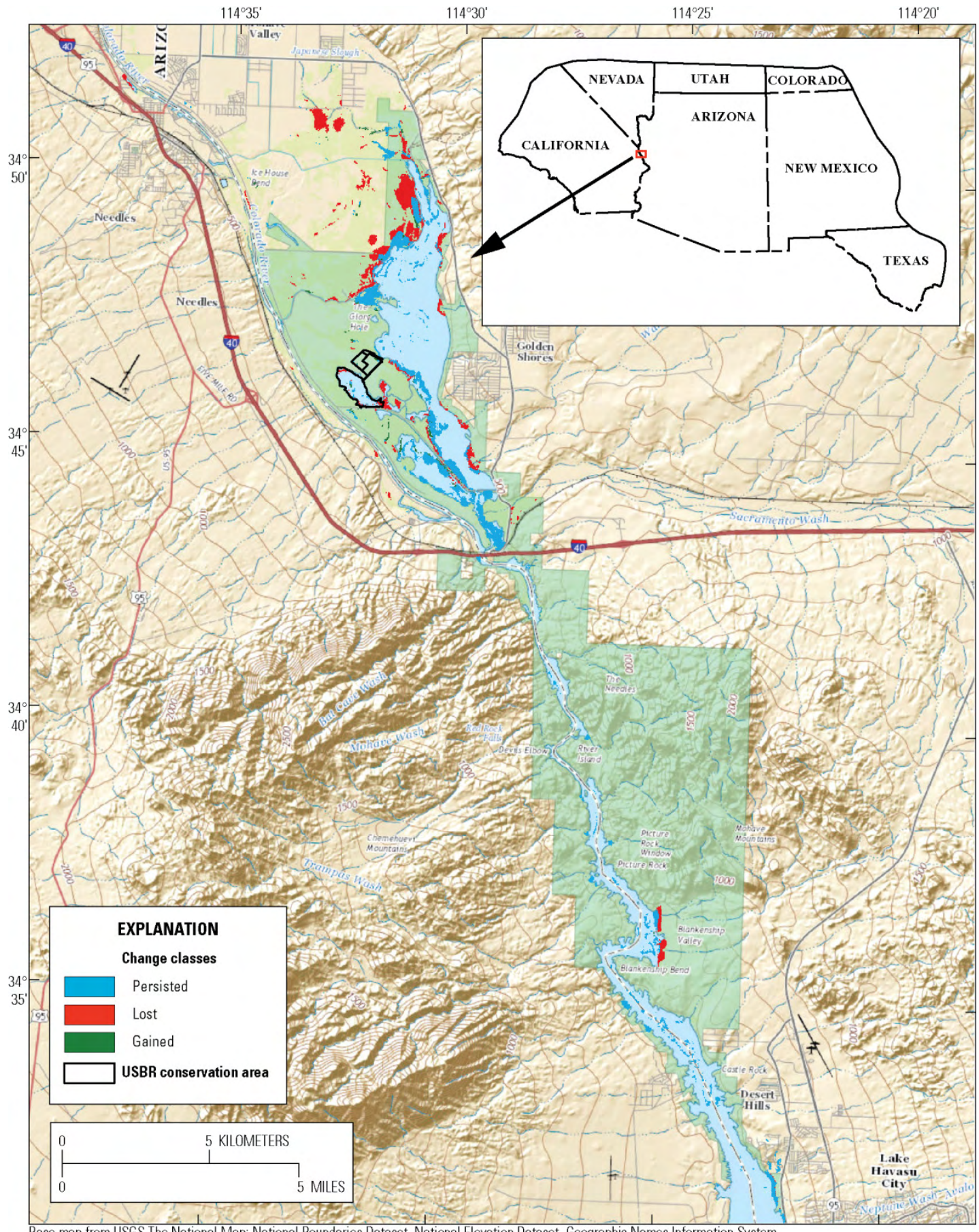

Base map from USGS The National Map: National Boundaries Dataset, National Elevation Dataset, Geographic Names Information System,

National Hydrography Dataset, National Land Cover Database, National Structures Dataset, and National Transportation

Dataset; U.S. Census Bureau - TIGER/Line; HERE Road Data

Figure 31. Map showing simulation results showing how tamarisk leaf beetles may affect flycatcher habitat at northern part (Topock Marsh) of Havasu National Wildlife Refuge along lower Colorado River, Arizona and California. Three possible change outcomes are (1) habitat persisted, (2) habitat declined (lost), and (3) habitat gained. Bureau of Reclamation conservation area boundaries are overlaid. Satellite model was used to predict flycatcher habitat at a 40-percent probability threshold. 


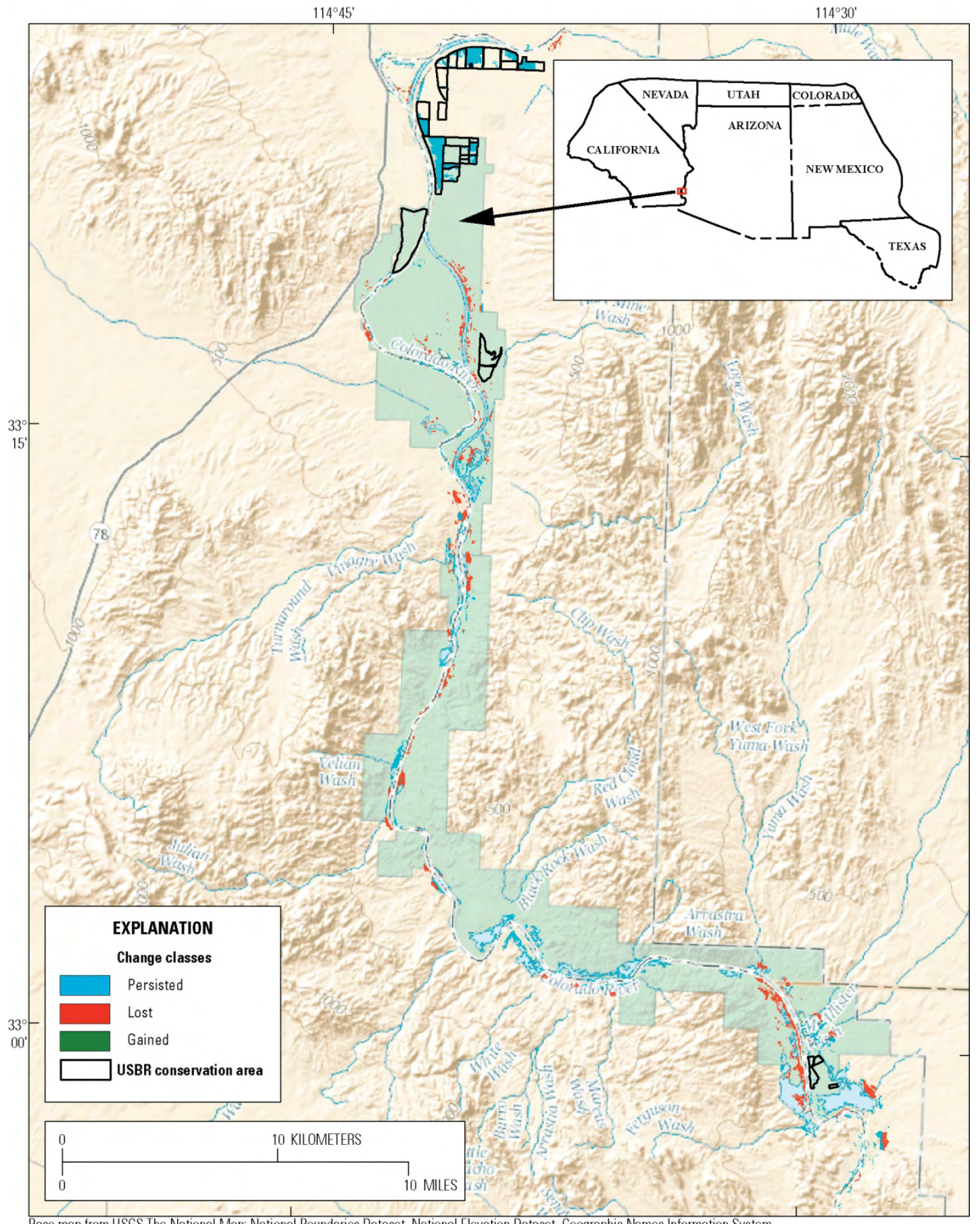

Base map from USGS The National Map: National Boundaries Dataset, National Elevation Dataset, Geographic Names Information System, National Hydrography Dataset, National Land Cover Database, National Structures Dataset, and National Transportation

Dataset; U.S. Census Bureau - TIGER/Line; HERE Road Data

Figure 32. Map showing simulation results showing how tamarisk leaf beetles may affect flycatcher habitat at Cibola National Wildlife Refuge along lower Colorado River, Arizona and California. Three possible change outcomes are (1) habitat persisted, (2) habitat declined (lost), and (3) habitat formed (gained). Bureau of Reclamation conservation boundary units are overlaid. Flycatcher model was used to predict flycatcher habitat at a 40-percent probability threshold. 


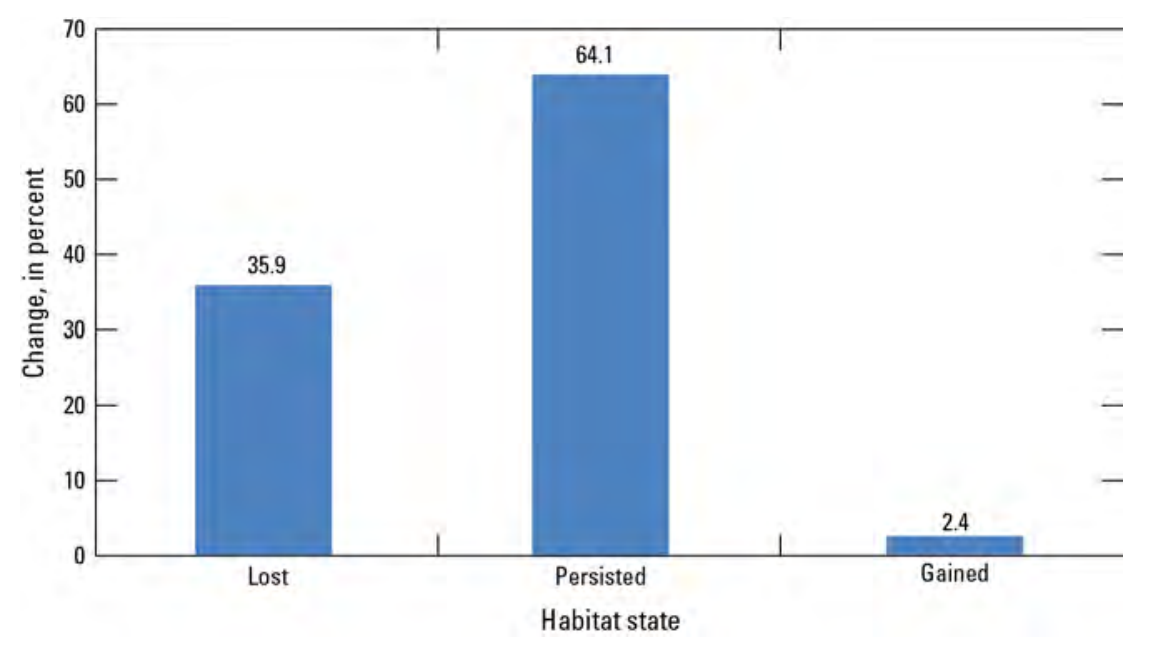

Figure 33. Graph showing three states of flycatcher habitat related to tamarisk leaf beetle-impact simulation along lower Colorado River, Arizona and California (see fig. 9). There were 4,658 ha of predicted habitat before the simulation, and 3,099 ha post-beetle simulation, representing a 33.5 percent reduction. Specifically, the postsimulation produced 113.5 ha of new flycatcher habitat, while 2,985.7 ha persisted and 1,672.3 ha were lost. A satellite model was used to predict flycatcher habitat at a 40-percent probability threshold.

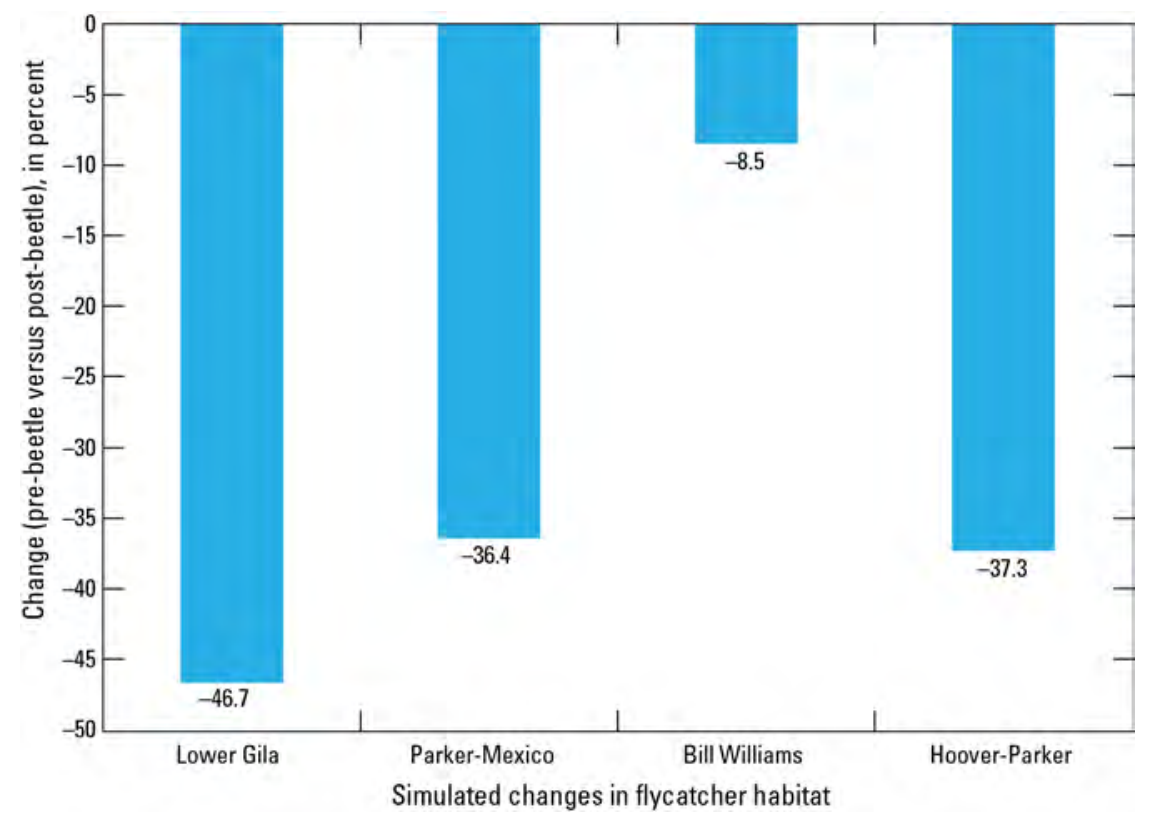

Figure 34. Graph showing changes in predicted flycatcher habitat along the lower Colorado River, by U.S. Fish and Wildlife Service management units(see fig. 9), after simulating a tamarisk leaf beetle infestation, Arizona and California. This analysis required that I run the flycatcher satellite model twice: once before the arrival of tamarisk leaf beetles (using 2015 imagery), and secondly, after NDVI values were artificially lowered in areas where tamarisk currently occurs. A satellite model was used to predict flycatcher habitat at a 40-percent probability threshold. 


\section{Upper Gila River}

The upper Gila River habitat time series indicated a cyclical pattern in predicted flycatcher habitat from 1986 to 2015 (fig. 35), with a mean of 1,214 ha per year, a standard deviation of 277 ha, and 95-percent CIs of 672-1,756 ha. The year 2002 produced the least amount of predicted habitat, at 684 ha, whereas 2008 produced the greatest amount (1,850 ha). Although the time series is ragged in appearance, there was a clear bimodal shape-1986-98 comprised the first hump, producing from 880 to 1,746 ha; 2007-15 comprised the second hump, producing from 936 to 1,850 ha; and 1999-06 comprised a trough, producing from 684 to 1,323 ha. The only year that exceeded the 95-percent CIs was 2008 (1,850 ha), but 1990 almost exceeded it (1,746 ha), whereas 2002 almost fell below it (684 ha).

A beetle-impact simulation for a 71-km reach of the upper Gila River resulted in a 53.1-percent loss in predicted flycatcher habitat, with 1,308 ha before the simulation and 613 ha afterwards, decreasing below two standard deviations calculated from 1986 to 2015 (fig. 36). Divided into three distinct habitat states, 719 ha of predicted habitat were lost (55.0\%), 25 ha were gained (1.9\%), and 588 ha $(45.0 \%)$ persisted (fig. 37). Divided into nine channel zones, habitat losses varied from 18.79 percent (zone 4) to 96.08 percent (zone 7) (fig. 38; table 6). Predicted changes in habitat by zone can be misleading without examining the amount of habitat involved. Specifically, zones 1-5 contained from 162.6 to 396.2 ha, compared with zones 6-9, which contained from 4.1 to 29.2 ha, making the magnitude of habitat loss much more significant in the first five zones. 


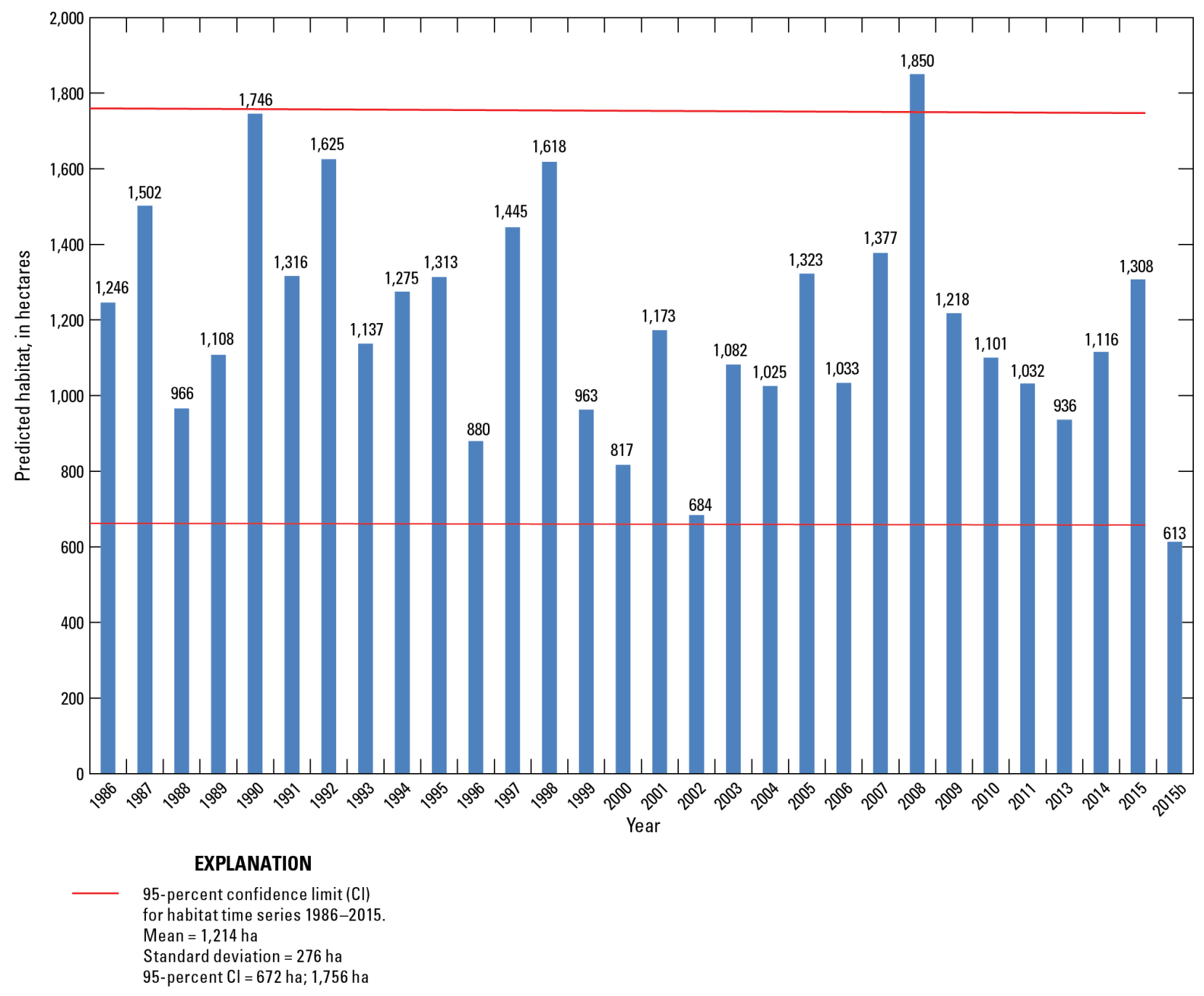

Figure 35. A habitat time series of predicted flycatcher habitat for upper Gila River, Arizona, from 1986 to 2015, plus the area of predicted flycatcher habitat after simulating a tamarisk leaf beetle infestation in 2015 (2015b). See table A5 for metadata on imagery used in this analysis. A satellite model was used to predict flycatcher habitat at a 40-percent probability threshold. 


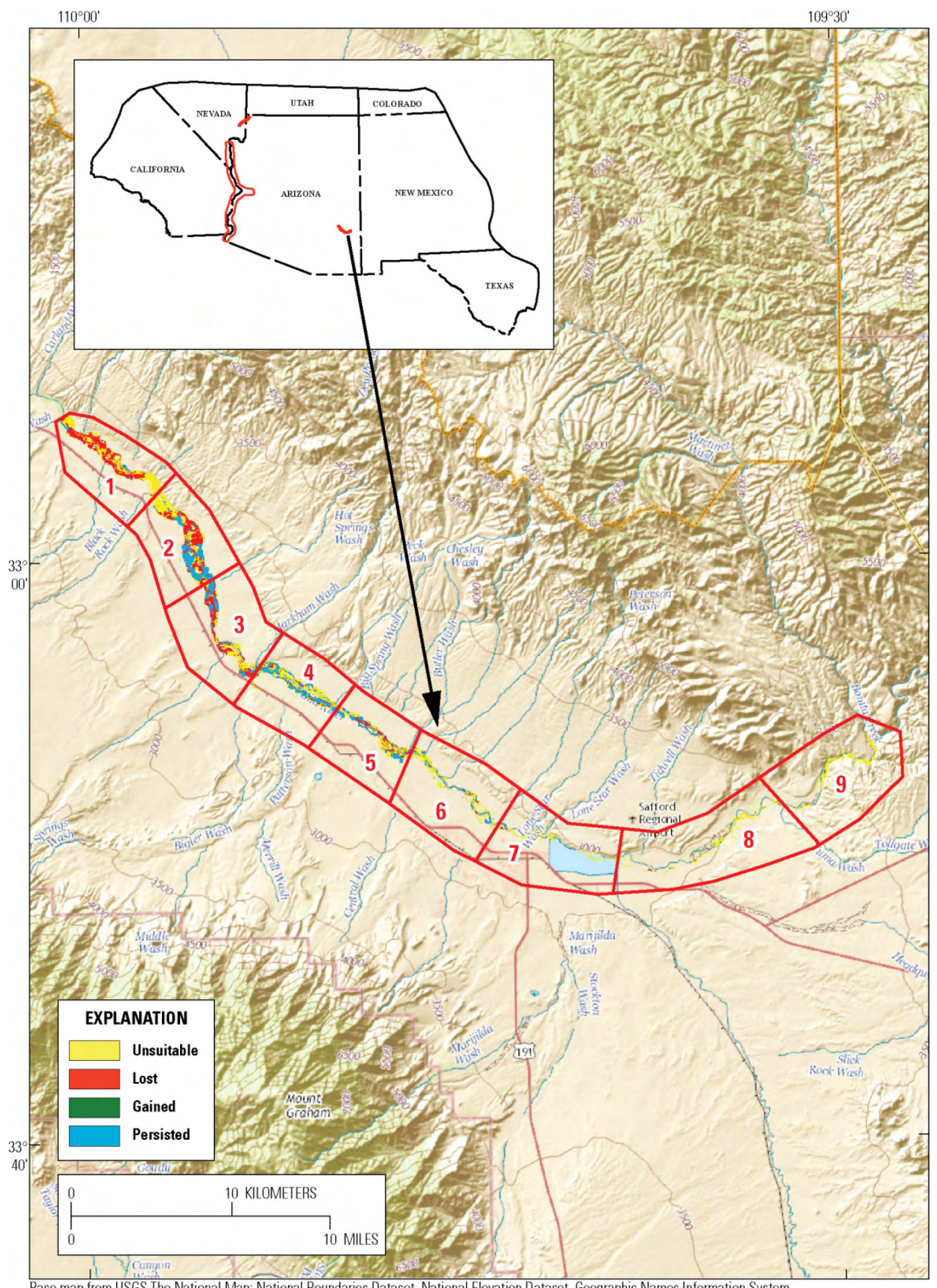

Base map from USGS The National Map: National Boundaries Dataset, National Elevation Dataset, Geographic Names Information System,

National Hydrography Dataset, National Land Cover Database, National Structures Dataset, and National Transportation

Dataset; U.S. Census Bureau - TIGER/Line; HERE Road Data

Figure 36. Map showing changes in predicted flycatcher habitat along the upper Gila River after conducting a tamarisk leaf beetle-impact simulation. The upper Gila River was divided into nine zones in order to quantify changes (see table 6 for the start and end points of each zone). A satellite model was used to predict flycatcher habitat at a 40-percent probability threshold. 


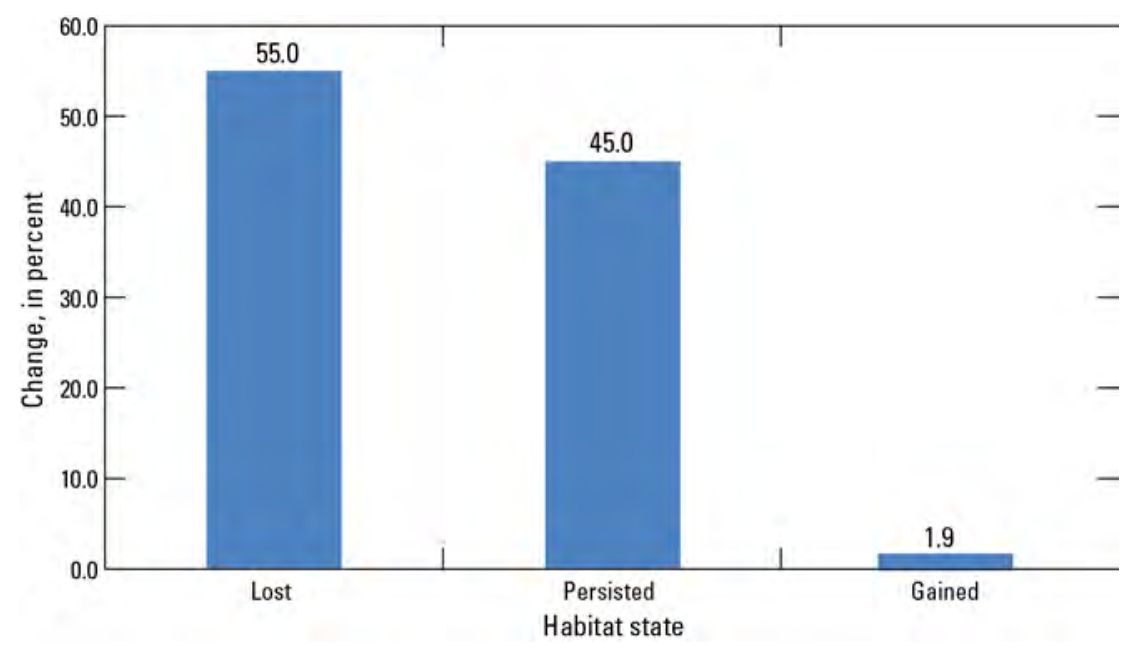

Figure 37. Graph showing three states of flycatcher habitat produced by a tamarisk leaf beetle-impact simulation along the upper Gila River (see fig. 10). Broken into three distinct habitat-change classes, 719 ha of habitat were lost, 25 ha were gained, while 588 ha persisted. A satellite model was used to predict flycatcher habitat at a 40percent probability threshold.

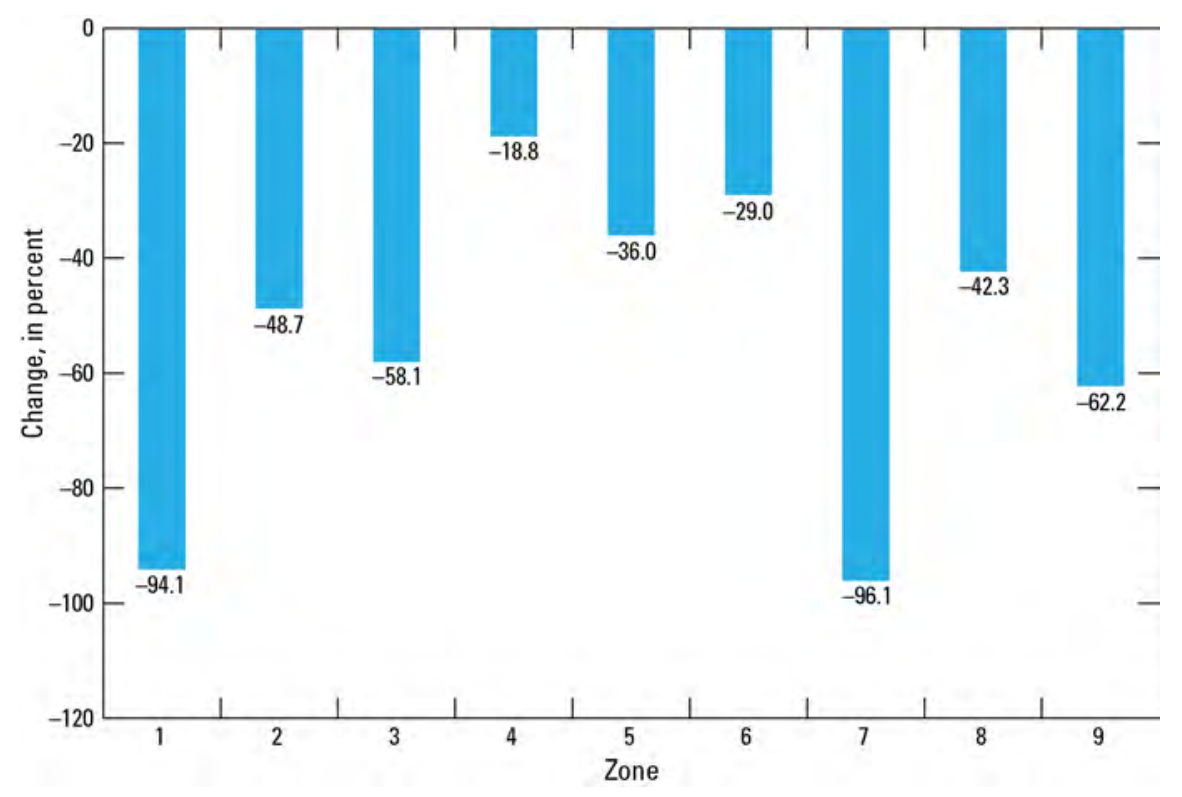

Figure 38. Graph showing simulated changes (percent) in predicted flycatcher habitat within 9 zones along the upper Gila River. A satellite model was used to predict flycatcher habitat at a 40-percent probability threshold. 
Table 6. Area of predicted flycatcher habitat before and after a tamarisk leaf beetle-impact simulation was done for the upper Gila River, Arizona.

[The satellite model produced the habitat estimates at a 40-percent probability threshold. The nine zones are delineated by rivers and creeks that are stored in the U.S. Geological Survey NHDPlus dataset. Zone: There are nine upper Gila River zones, as shown in figure 36. Habitat_pre: Flycatcher habitat (hectares) before leaf beetle-impact simulation was done. Habitat_post: Flycatcher habitat (hectares) after leaf beetle-impact simulation was done. Change: Simulated change in predicted flycatcher habitat after a leaf beetle-impact simulation was done]

\begin{tabular}{ccccl}
\hline \multirow{2}{*}{ Zone } & \multicolumn{2}{c}{ Habitat area (hectares) } & \multirow{2}{*}{ Change } & \multicolumn{1}{c}{ Description } \\
\cline { 2 - 3 } & Habitat_pre & Habitat_post & & \\
\hline 1 & 248.8 & 14.6 & -94.14 & Goodwin Wash to Black Rock Wash \\
2 & 396.2 & 203.1 & -48.73 & Black Rock Wash to Hot Springs Wash \\
3 & 264.5 & 110.9 & -58.08 & Hot Springs Wash to Markham Wash \\
4 & 187.7 & 152.5 & -18.79 & Markham Wash to Pack Wash \\
5 & 162.6 & 104.0 & -36.03 & Peck Wash to Butler Wash \\
6 & 29.2 & 20.7 & -29.01 & Butler Wash to Peterson Wash \\
7 & 4.6 & 0.2 & -96.08 & Peterson Wash to San Simon River \\
8 & 10.0 & 5.8 & -42.34 & San Simon River to Yuma Wash \\
9 & 4.1 & 1.5 & -62.22 & Yuma Wash to Bonita Creek \\
\hline
\end{tabular}

\section{Discussion}

\section{Key Findings and a Path Forward}

This report presents the first predictive, regionwide map of flycatcher breeding habitat, and there are numerous findings likely to be of interest to natural resource managers, habitat modelers, and avian ecologists:

1. A rangewide change-detection map that provides new insights into the formation and loss of predicted flycatcher breeding habitat;

2. A hierarchical ranking of predicted flycatcher habitat at multiple scales - rangewide, statewide, FWS management units, critical-habitat reaches, and U.S. Geological Survey 7.5minute quadrangles;

3. A set of spatially explicit maps that show predicted flycatcher habitat in binary or fiveprobability class formats for 2013-15;

4. A rangewide accuracy assessment with a robust set of territories obtained from 2014; and

5. An assessment of beetle impacts along the lower Virgin River from 2010 to 2015, and beetle-impact simulations along the lower Colorado and upper Gila Rivers in 2015. 


\section{Habitat Change Detection}

Predicted flycatcher habitat increased 58.8 percent along a lateral west-east gradient from 2013 to 2015, suggesting that regional weather patterns were responsible for greening and graying of riparian zones. The greening of riparian zones, as indicated by an increase in predicted flycatcher habitat from 2013 to 2015, was especially pronounced along the Rio Grande in southwestern Texas, the Pecos River in southeastern New Mexico, and the Rio Grande in western New Mexico (fig. 23). This pattern changed abruptly in Arizona where there was considerable variability in the state of flycatcher habitat, with some rivers exhibiting a checkerboard pattern of graying and greening from headwaters to mouth. The major tributaries of the Gila River (for example, San Pedro, Verde, San Francisco Rivers) all showed a considerable decrease in predicted flycatcher habitat (riparian areas became less lush), whereas the main stem Gila River showed increased lushness and flycatcher habitat along many reaches. There was another transition in California where most rivers and streams showed a pronounced decrease in predicted flycatcher habitat that indicated a loss of vigor in the riparian vegetation related to drought. These observations are strongly supported by U.S. Drought Monitor Maps (U.S. Department of Agriculture, 2015) that clearly show how the drought increased in the Western United States and decreased in the Eastern United States from 2013 to 2015 (fig. 39). The strong response of the satellite model to drought is not surprising because NDVI is a key component of the flycatcher model and is very sensitive to moisture and temperature (Williams and others, 2013). At finer scales, large interannual changes in predicted flycatcher habitat have been documented owing to drought, flooding, and surface and groundwater conditions (Hatten and others, 2010; Orr and others, 2014).

The largest changes in predicted flycatcher habitat in 2015 were at reservoir inflows and riverine reaches. This is not surprising because fluctuating water levels caused by seasonal runoff or reservoir operations can result in optimal seed deposition and germination zones for riparian vegetation (Shafroth and others, 1998; Paradzick and Hatten, 2004). Young, lush vegetation in reservoir drawdown zones has been shown to be heavily favored by breeding flycatchers (Paxton and others, 2007). At Roosevelt Lake in south-central Arizona, the satellite model provided habitat estimates that explained 79 percent of the inter-annual variability in a fluctuating flycatcher population from 1996 to 2004 (Hatten and others, 2010). Additionally, flycatcher populations along Alamo Lake in eastern Arizona occur in areas predicted to be suitable by the satellite model (Hatten and Paradzick, 2003). In addition to lake deltas, riverine areas that have interval flooding can result in favorable flycatcher breeding habitat, such as the lower Bill Williams River or Rio Grande (Dockens and others, 2004; Hatten and Sogge, 2007). 

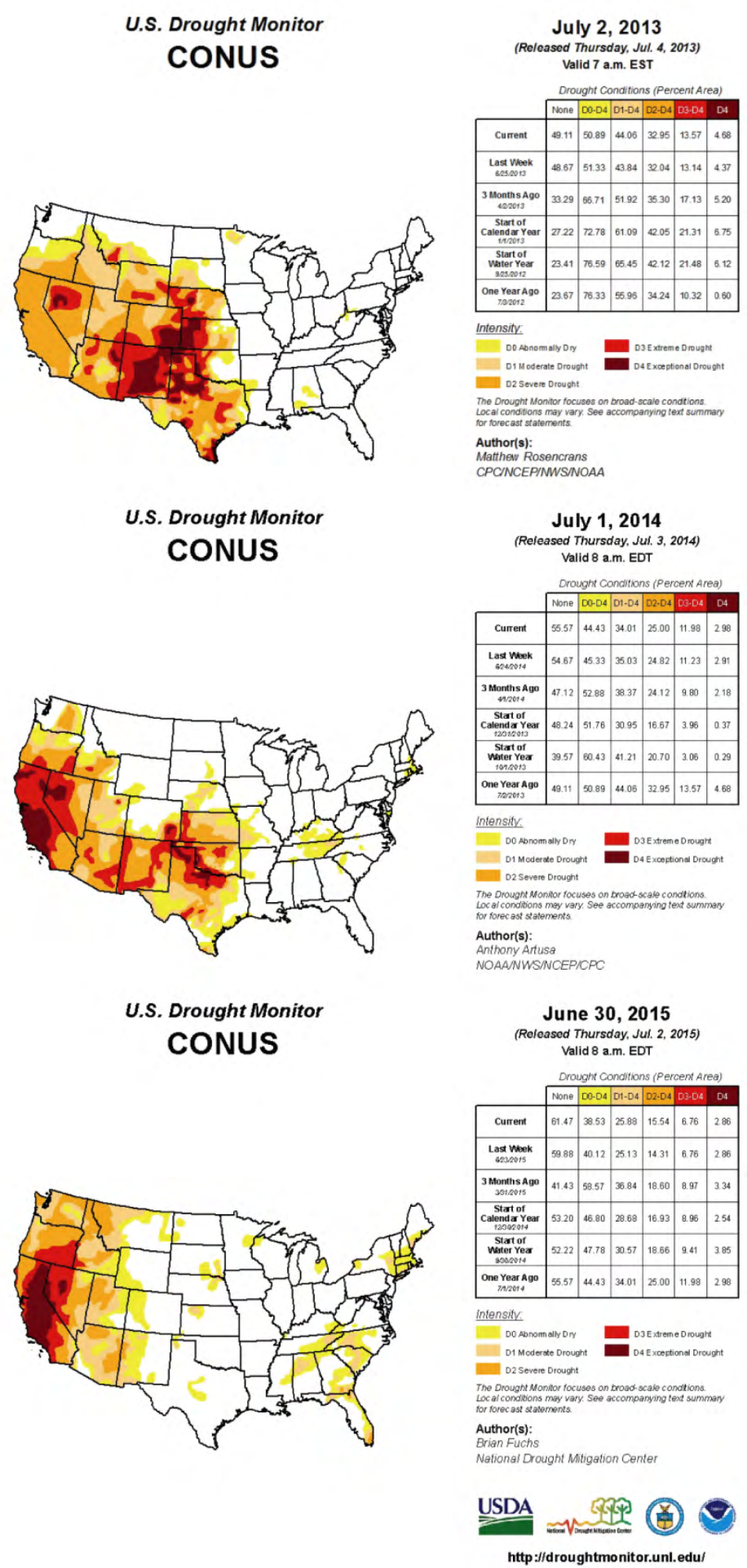

Figure 39. Drought maps portray a drought that intensifies to the west and decreases in the eastern portion of the study area from 2013 to 2015 (U.S. Department of Agriculture, 2015). 


\section{Rangewide Ranking of Flycatcher Breeding Habitat}

An intriguing part of this study was the identification of potentially new flycatcher breeding locations that have never been surveyed, or have not been visited in years. Given the scarcity of resources available to fund field surveys, this mapping effort could be used to identify and prioritize survey efforts. For example, the greening of the eastern part of flycatcher range could indicate that additional surveys are necessary along parts of the lower Rio Grande and Pecos River in eastern Texas. Although these areas only had only one documented breeding site (Durst and others, 2008), the satellite model indicates that the probability of favorable habitat has increased substantially from 2013 to 2015 .

Managers can be confident that the probability classes of the satellite model are a useful tool for prioritizing survey and restoration/enhancement efforts. For example, the likelihood of flycatcher territories is much greater in higher probability classes, with less than 12 percent in classes 1 or 2, thus, higher probability classes could be prioritized when survey funds are scarce (fig. 17). Using similar logic, it may be more economical to restore/enhance locations that are in the middle-probability range, such as class 3 , because it is already much more likely to contain a flycatcher territory than classes 1 or 2 (2.7 to 6 times, fig. 17). Such a strategy currently (2016) is being used along the upper Gila River in southeastern Arizona (near Fort Thomas), where tamarisk is being selectively removed and replaced with native willows before beetles arrive (Johnson and Calvo, 2014; Orr and others, 2014; Johnson, 2016).

\section{Accuracy Assessment}

A key question of this study was whether the performance of the satellite model was acceptable throughout the range of the flycatcher. The answer is "yes." Specifically, the accuracy of the satellite model in 2014 was 88 percent $(n=758)$ at a 40-percent cutpoint, with the remaining territories occurring on average only $74 \mathrm{~m}$ from predicted habitat. This accuracy assessment had a sample size that was 58 percent as large as the total known territories (1,299) rangewide since 1993 (Durst and others, 2008). Furthermore, these accuracy results compare favorably to other flycatcher mapping efforts in southcentral Arizona (Paxton and others, 2007; Hatten and others, 2010) and the Rio Grande, New Mexico (Hatten and Sogge, 2007). The fit of the model was respectable, with a clear exponential relationship between territory densities and five probability classes.

A discussion about model accuracy is not complete without consideration of map accuracy because they are not the same thing (see Story and Congalton, 1986). For example, if the satellite model produces a 90 -percent probability at a specific location $(30 \times 30-\mathrm{m}$ cell $)$, that does not mean that there is a 90-percent chance that a flycatcher territory will occur there, nor does it mean that it is flycatcher habitat. The only way to determine map accuracy from a user perspective is to randomly survey a set of locations in a given reach to determine their suitability (although there is subjectivity in visual classifications). After a given number of locations are randomly visited in each probability class, field results can be compared with model predictions (producer accuracy) using a classification table (error matrix). This approach was attempted after the first statewide mapping effort in 2001 (see Dockens and others, 2004), but it was limited because of budget constraints and logistical considerations (private access rights, etc.). However, results of Dockens and others (2004) are consistent with model accuracy because field-map misclassification decreased in high probability classes and increased in low probability classes. 
The difficulties encountered in this field verification exercise actually reinforced the strengths of the satellite mode; mainly, that it can be consistently and cheaply applied without bias, provided the underlying ruleset (as described in the section, "Methods") is not altered during model application.

\section{Beetle-Impact Analysis and Simulations}

This is the first time that the flycatcher satellite model has been used to measure the impacts of the beetle on its habitat. The results are dramatic, largely because most of the lower Virgin River is comprised of tamarisk habitat. In areas that have reduced amounts of tamarisk and dominant native vegetation, losses to predicted flycatcher habitat likely will be less extreme. These results mirror previous studies that have shown large decreases in the vigor and lushness of tamarisk following beetle colonization in the upper Colorado and Dolores Rivers, Utah (Dennison and others, 2009), Humboldt and Walker Rivers, Nevada (Pattison and others, 2011), and lower Virgin River, Nevada and Arizona (Bateman and others, 2013; Nagler and others, 2014; Bateman and Johnson, 2015). Although these studies used different methods and satellite sensors, the conclusions of each study are very similar with regard to the impacts of the beetle on tamarisk. This study went a step further by linking decreases in tamarisk vitality to flycatcher breeding habitat.

The beetle-impact simulations provide information to managers of potential decreases in flycatcher habitat should beetles colonize the Lower Colorado or upper Gila Rivers. The best vegetation maps available were used for these reaches, but neither map had an accuracy assessment (Bangle and others, 2014; Neale and others, 2014), so caution is warranted when evaluating the beetle-impact simulations. On the lower Virgin River, which was not a simulation, only 5.8 percent of predicted flycatcher habitat persisted from 2010 to 2015 (beetles introduced in 2008), whereas simulation results indicated that 45 percent will persist along the upper Gila River and 64.1 percent will persist along the Lower Colorado River. On the upper Gila River, most of the predicted habitat was in zones 1-5 (fig. 36), where predicted decreases in flycatcher habitat ranged from 18.8 to 94.1 percent. Beetles are not yet present on the upper Gila River; subtropical tamarisk beetles are currently (2016) predicted to arrive from western Texas and northern Arizona and New Mexico in 2-3 years (J. Tracy, Texas A\&M University, written commun., April 2016) (fig. 2). The situation seems worse on the lower Colorado River, where northern tamarisk beetles have been moving steadily downstream and subtropical tamarisk beetles moving west will likely colonize the entire reach in the next 3-5 years (J. Tracy, Texas A\&M University, written commun., April 2016).

The beetle-impact simulations can help guide restoration/enhancement actions across the range of the flycatcher. Proactive efforts are occurring to minimize beetle effects on flycatcher habitat at multiple locations. The Gila Watershed Partnership is working proactively in zones 1-5 (fig. 36) by initiating habitat restoration at sites that currently provide breeding habitat for Southwestern Willow Flycatchers and yellow-billed cuckoos (Coccyzus americanus). However, because of the anticipated arrival of the tamarisk leaf beetle (Diorhabda spp.), this organization is taking action now that will restore native habitat, minimize impacts of the beetle, and conserve this vulnerable riparian ecosystem (Orr and others, 2014). A similar proactive effort is occurring 
along the lower Colorado River, where Reclamation is replacing agricultural plantations with native vegetation more suitable to flycatchers and other native birds, such as yellow-billed cuckoos. The satellite model identified multiple native plantations as high-probability flycatcher habitat (fig. 32), providing support so that restoration and enhancement efforts can help minimize projected impacts from invasive beetles or natural disasters such as flooding, fire, or drought.

\section{Next Steps}

\section{Occupancy Modeling}

Linking an occupancy model to the satellite model might significantly improve the ability to identify where flycatchers occur on an annual basis (MacKenzie and others, 2006). Satellite model simulations identify predicted flycatcher habitat and produce territory density estimates within five probability classes, but they cannot estimate the likelihood that a flycatcher will occur. Large areas of predicted flycatcher habitat are vacant in some years but become occupied in subsequent years (U.S. Fish and Wildlife Service, 2002). Researchers have gathered considerable amounts of information related to flycatcher movement and habitat preferences (Paxton and others, 2007), but we lack the ability to predict which patches will become occupied as local or regional conditions change. The satellite model provides a foundation upon which an occupancy model could be built; the missing piece of the puzzle is a more complete accounting of flycatcher territories rangewide. I used 758 territories obtained in 2014 that were in GIS or spreadsheet format, but there were other locations handwritten on hard-copy maps that were not included in the analysis, indicating the importance of updating the regionwide flycatcher database on an annual basis (Durst and others, 2008). Three to five years of survey efforts coupled with satellite model results should provide sufficient data to produce an occupancy model (MacKenzie and others, 2006). A new suite of predictor variables would need to be created from the satellite model output, such as quantity of predicted habitat within different radii (Hatten and Paradzick, 2003), proximity to different sized creeks and rivers obtained from the NHDPlus database (McKay and others, 2012), location (FWS management unit, 7.5-minute quadrangle, HUCHydrologic Unit Code, easting), and number of years a site has been above or below a given probability threshold (Hatten and others, 2010).

\section{Automated Cloud-Based Mapping}

The methods and results presented in this report could be used in the development of an automated cloud-based mapping application. Specifically, the satellite model algorithms could be applied automatically to Landsat scenes that are being collected monthly by Google Earth ${ }^{\mathrm{TM}}$ mapping service from the U.S. Geological Survey EROS Data Center (Google Earth ${ }^{\mathrm{TM}}$, 2016a). Created in cooperation with the U.S. Geological Survey, Google Earth ${ }^{\mathrm{TM}}$ Engine was developed as a planetary application that could track changes in forest cover (Regalado, 2010). Through Google Earth Engine, users could access flycatcher habitat maps with an interactive Internet mapping application, similar to the recent Google Earth ${ }^{\mathrm{TM}}$ Engine application developed for sage grouse (U.S. Department of Agriculture, 2016), specifying an area of interest (for example, polygon) and date (could be multiple years). Google Earth ${ }^{\mathrm{TM}}$ Engine could enable quick and efficient rangewide maps to be created and the development of habitat time series for any locations from 1986 to the present (Google Earth ${ }^{\mathrm{TM}}, 2016 \mathrm{~b}$ ). 


\section{Acknowledgments}

I thank Mark Sogge (U.S. Geological Survey) and Carol Evans (U.S. Bureau of Reclamation) for helping with project initiation and coordination, and Thomas Batt (USGS) for downloading and organizing Landsat data. I thank Susan Sferra, Greg Beatty, and Scott Durst of the U.S. Fish and Wildlife Service for providing logistical, technical, and administrative support. I also thank the following individuals for providing verification data: Sonja Kokos (Bureau of Reclamation), Vicki Ryan (U.S. Fish and Wildlife Service), Darrell Ahlers (Bureau of Reclamation), Barbara Kus and Scarlett Howell (USGS), Matthew Johnson (Northern Arizona University), Lacey Green (California Department of Fish and Wildlife), and Martha Schuman (The Nature Conservancy). I also thank Eben Paxton, Linda Rogers, John Osias, and Barbara Ralston (U.S. Geological Survey), and Matthew Johnson (Northern Arizona University), for providing useful comments that greatly improved this paper, and Luis Menoyo (U.S. Geological Survey) for graphical support. A hearty thanks to all the nameless field technicians that labored to collect territory and nest locations throughout the flycatcher's range. Lastly, I thank James Tracy (Texas A\&M University) for providing useful information related to tamarisk beetles.

\section{References Cited}

Anderson, B.W., and Ohmart, R.D., 1984, Lower Colorado River riparian methods of quantifying vegetation 13 communities to prepare type maps: Final report prepared for the Bureau of Reclamation, Lower Colorado Region, Boulder City, Nevada.

Bateman, H.L., Nagler, P.L., and Glenn, E.P., 2013, Plot- and landscape-level changes in climate and vegetation following defoliation of exotic saltcedar (Tamarix sp.) from the biocontrol agent Diorhabda carinulata along a stream in the Mojave Desert (USA): Journal of Arid Environments, v. 89, p. 16-20.

Bateman, H.L., and Johnson, M.J., 2015, Effects of biocontrol and restoration on wildlife in Southwestern riparian habitats: Report submitted to Southern Rockies and Desert Landscape Conservation Cooperative.

Bangle, D., Ahlbrandt, R., Baker, M., and Milliken, J., 2014, 2010-2011 vegetation mapping along the lower Colorado River . Bureau of Reclamation, unpub. report, $74 \mathrm{p}$.

Bean, D.W., Dudley, T., and Huletine, K., 2013, Bring on the beetles!-The history and impact of tamarisk biological control, in Sher, A., and Quigley, M.F., eds., Tamarix-A case study of ecological change in the American West: New York, Oxford University Press, p. 377-403.

Chander, G., Markham, B.L., and Helder, D.L., 2009, Summary of current radiometric calibration coefficients for Landsat MSS, TM, ETM+, and EO-1 sensors: Remote Sensing of Environment, v. 113, p. 893-903.

Chew, M.K., 2013, Tamarisk introduction, naturalization, and control in the United States, 1818-1952, in Sher, A., and Quigley, M.F., eds., Tamarix-A case study of ecological change in the American West; New York, Oxford University Press, p. 269-286.

DeLoach, C.J., Carruthers, R., 2004, Biological control programs for integrated invasive plant management, in Proceedings of Weed Science Society of America Meeting, Kansas City, Missouri: Weed Science Society of America (CD-ROM), 17 p.

Dennison, P.E, Nagler, P.L., Hultine, K.R., Glenn, E.P., and Ehleringer, J.R., 2009, Remote monitoring of tamarisk defoliation and evapotranspiration following saltcedar leaf beetle attack: Remote Sensing of Environment, v. 113, p. 1,462-1,472.

Dobbs, R. C., Huizinga, M., Edwards, C.N., and Fridell, R., 2012, Status, reproductive success, and habitat use of Southwestern willow flycatchers on the Virgin River, Utah, 2008-2011: Publication Number 12-36, Utah Division of Wildlife Resources. 
Dockens, P.E.T., Paradzick, C.E., and Hatten, J.R., 2004, Application of a Southwestern willow flycatcher GIS-based habitat model-An estimate of breeding habitat in Arizona, 2001, in Dockens, P.E.T., and Paradzick, C.E., eds., Mapping and monitoring Southwestern willow flycatcher breeding habitat in Arizona-A remote sensing approach: Phoenix, Arizona Game and Fish Department Nongame and Endangered Wildlife Program Technical Report 223, p. 28-59.

Durst, S.L., Sogge, M.K., Stump, S.D., Walker, H,A, Kus, B.E., and Sferra, S.J., 2008. Southwestern willow flycatcher breeding sites and territory summary-2007: U.S. Geological Survey Open-File Report 2008-1303, http://pubs.usgs.gov/of/2008/1303.

Google Earth, 2016a, A planetary-scale platform for Earth science data and analysis: Google Earth Engine Web site, accessed February 29, 2016, at https://earthengine.google.com/.

Google Earth, 2016b, Timelapse: Google Earth Engine Web site, accessed February 29, 2016, at https://earthengine.google.com/timelapse/.

Hatten, J.R., 2014, Mapping and monitoring Mount Graham red squirrel habitat with lidar and Landsat imagery: Ecological Modelling, v. 289, p. 106-123.

Hatten, J.R., and Paradzick, C.E., 2003, A multiscaled model of southwestern willow flycatcher breeding habitat: Journal of Wildlife Management, v. 67, p. 774-788.

Hatten, J.R., Paxton, E.H., and Sogge, M.K., 2010, Modeling the dynamic habitat and breeding population of Southwestern willow flycatcher: Ecological Modelling, v. 221, p. 1,674-1,686.

Hatten, J.R., and Sogge, M.K., 2007, Using a remote sensing/GIS model to predict Southwestern willow flycatcher breeding habitat along the Rio Grande, New Mexico: U.S. Geological Survey Open-File Report 2007-1207, http://pubs.usgs.gov/of/2007/1207/.

Hultine, K.R., Belnap, J., van Riper, C., III, Ehleringer, J.R., Dennison, P.E., Lee, M.E., Nagler, P.E., Snyder, K.A., Uselman, S.M., and West, J.B., 2009, Tamarisk biocontrol in the Western United States-Ecological and societal implications: Frontiers in Ecology and the Environment e-View, doi: 10.1890/090031.

Hultine, K.R., Dudley, T.L., Koepke, D.F., Bean, D.W., Glenn, E.P., and Lambert, A.M., 2015, Patterns of herbivory-induced mortality of a dominant non-native tree/shrub (Tamarix spp.) in a Southwestern US watershed: Biological Invasions, doi: 10.1007/s10530-014-0829-4.

Jamison, L.R., van Riper, C., III, and Bean, D.W., 2015, The influence of Tamarix ramosissima defoliation on population movements of the Northern tamarisk beetle (Diorhabda carinulata) within the Colorado Plateau, in Huenneke, L.F., van Riper, C., III, and Hays-Gilpin, K.A., The Colorado Plateau VI-Science and management at the landscape scale: Tucson, University of Arizona Press, $\mathrm{p}$. 289-300, Project MUSE, https://muse.jhu.edu/,

Johnson, M.J., 2016, Gila River, AZ Southwestern willow flycatcher and yellow-billed cuckoo surveys and nest monitoring for proposed restoration sites, 2015: Annual report submitted to Gila Watershed Partnership of Arizona and U.S. Fish and Wildlife Service,. 42 p.

Johnson, M.J., and Calvo, C.M., 2014, Virgin River tamarisk removal and restoration and its effects on Southwestern willow flycatchers - Virgin River, Arizona assessment and recommendations: Annual report submitted to Arizona State Forestry Division, $113 \mathrm{p}$.

Johnson, M.J., and Jamison, L.R.. 2015, Tamarisk leaf beetle species distribution in Rio Grande River watershed, New Mexico, 2015: Bosque Ecosystem Monitoring Program, Annual Report submitted to the Army Corp of Engineers, Albuquerque, New Mexico, 71 p.

Lowry, J.H, Jr., Ramsey, R.D., Boykin, K., Bradford, D., Comer, P., Falzarano, S., Kepner, W., Kirby, J., Langs, L., Prior-Magee, J., Manis, G., O’Brien, L., Sajwaj, T., Thomas, K.A., Rieth, W., Schrader, S., Schrupp, D., Schulz, K., Thompson, B., Velasquez, C., Wallace, C., Waller, E., and Wolk, B., 2005, Southwest regional gap analysis project-Final report on land cover mapping methods: Logan, Utah State University, RS/GIS Laboratory. 
MacKenzie, D.I., Nichols, J.D., Royle, J.A., Pollock, K.H., Bailey, L.L., Hines, J.E., 2006, Occupancy estimation and modeling-Inferring patterns and dynamics of species occurrence: San Diego, Academic Press.

McKay, L., Bondelid, T., Rea, A., Johnston, C., Moore, R., and Dewald, T., 2012, NHDPlus Version 2-User Guide: Prepared for U.S. Environmental Protection Agency, 159 p.

Nagler, P.L., Pearlstein, S., Glenn, E.P., Brown, T.B., Bateman, H.L., Bean, D.W., and Hultine, K.R., 2014, Rapid dispersal of saltcedar (Tamarix spp.) biocontrol beetles (Diorhabda carinulata) on a desert river detected by phenocams, MODIS imagery and ground observations: Remote Sensing of Environment, v. 140, p. 206-219.

Neale, C.M.U., Akasheh, O., and McGinty, C., 2014, Mapping the geomorphology and vegetation in the Gila River riparian corridor to support restoration planning and assessment: Logan, Utah State University, Department of Civil and Environmental Engineering, unpub. report, 17 p.

Orr, B.K., Leverich, G.T., Diggory, Z.E., Dudley, T.L., Hatten, J.R., Hultine, K.R., Johnson, M.P., and Orr, D.A., 2014, Riparian restoration framework for the upper Gila River, Arizona: Prepared for the Gila Watershed Partnership of Arizona, 57 p. with appendixes.

Paradzick, C.E., and Hatten, J.R., 2004, Southwestern willow flycatcher habitat change detection analysis-Roosevelt Lake, Arizona, 1985-2001 in Dockens, P.E.T., and Paradzick, C.E., eds., Mapping and monitoring Southwestern willow flycatcher habitat in Arizona-A remote sensing approach: Phoenix, Arizona Game and Fish Department Nongame and Endangered Wildlife Program Technical Report 223, p. 60-82.

Pattison, R.R., D’Antonio, C.M., Dudley, T.L., Allander, K.K., and Rice, R., 2011, Early impacts of biological control on canopy cover and water use of the invasive saltcedar tree (Tamarix spp.) in western Nevada, USA: Oecologia, v. 165, p. 605-616.

Paxton, E.H., Sogge, M.K., Durst, S.L., Theimer, T.C., and Hatten, J.R., 2007, Spatial Modeling, chap. 6 of The ecology of the Southwestern willow flycatcher in central Arizona-A 10-year synthesis report: U.S. Geological Survey Open-File Report 2007-1381, p 97-124.

Paxton, E.H., Theimer, T.C., and Sogge , M.K., 2011, Tamarisk biocontrol using tamarisk beetlesPotential consequences for riparian birds in the Southwestern United States: The Condor, v. 113, no, 2, p. 255-265.

Regalado, A., 2010, New Google Earth Engine: Science magazine online, accessed February 29, 2016, at http://www.sciencemag.org/news/2010/12/new-google-earth-engine.

Shafroth, P.B., Auble, G.T., Stromberg, J.C., and Patten, D.T., 1998, Establishment of woody riparian vegetation in relation to annual patterns of stream flow, Bill Williams River, Arizona: Wetlands, v. 18, p. 577-590.

Sogge, M.K., Ahlers, D., and Sferra, S.J., 2010, A natural history summary and survey protocol for the Southwestern willow flycatcher: U.S. Geological Survey Techniques and Methods, book 2, chap. A10, http://pubs.usgs.gov/tm/tm2a10/. 
Sogge, M.K., and Marshall, R.M., 2000, Chapter 5: A survey of current breeding habitats, in Finch, D.M., and Stoleson, S.H., eds., Status, ecology, and conservation of the Southwestern Willow Flycatcher: U.S. Forest Service Rocky Mountain Research Station General Technical Report-60, p. 43-56.

Sogge, M.K., Paxton, E.H., and van Riper, C., III, 2013, Tamarisk in riparian woodlands - A bird's eye view, in Sher A., and Quigley, M.F., eds., Tamarix - A case study of ecological change in the American West: New York, Oxford University Press, p. 189-206.

Sogge, M.K., Sferra, S.J., and Paxton, E.H., 2008, Tamarix as habitat for birds-Implications for riparian restoration in the Southwestern United States: Restoration Ecology, v. 16, p. 146-154.

Story, M., Congalton, R.G., 1986. Accuracy assessment: a user's perspective. Photogramm. Eng. Remote Sens. 52, 397-399.

U.S. Fish and Wildlife Service, 1995, Final rule determining endangered status for the Southwestern willow flycatcher: Federal Register, v. 60, no. 38, p. 10694-10715.

U.S. Fish and Wildlife Service, 2002, Southwestern willow flycatcher final recovery plan: U.S. Fish and Wildlife Service, Albuquerque, New Mexico.

U.S. Fish and Wildlife Service, 2013, Designation of critical habitat for Southwestern willow flycatcher-Final rule: Federal Register, v. 78, no. 2., p. 344-534. [Also available at http://www.regulations.gov, Docket No. FWS-R2-ES-2011-0053.]

U.S. Department of Agriculture, 2015, U.S. Drought Monitor (home page): Lincoln, Nebraska, National Drought Mitigation Center Web site, accessed February 24, 2016, at http://droughtmonitor.unl.edu/.

U.S. Department of Agriculture, 2016, Sage grouse initiative-Interactive viewer: Sage Grouse Initiative Web site, accessed February 29, 2016, at http://map.sagegrouseinitiative.com/.

U.S. Geological Survey, 2005, Global Visualization (GloVis) viewer: U.S. Geological Survey Fact Sheet 2005-3118, 1 p., accessed February 11, 2016, at http://glovis.usgs.gov/.

Williams, A.P., Allen, D.A., Macalady, A.K., Griffin, D., Woodhouse, C.A., Meko, D.M., and others, 2013, Temperature as a potent driver of regional forest drought stress and tree mortality: Nature Climate Change, v. 3, p. 292-297. 


\section{Appendix A. Metadata for Landsat Scenes Used in Regionwide Mapping and Habitat Time Series}

Table A1. Metadata for 57 Landsat scenes used to model flycatcher breeding habitat rangewide, Southwestern United States, 2013.

[UTM zone: Universal Transverse Mercator zone]

\begin{tabular}{lcccc}
\hline \multicolumn{1}{c}{ Date } & Scene_ID & UTM zone & Clouds & $\begin{array}{c}\text { Quality } \\
\text { ranking }\end{array}$ \\
\hline 6/1/2013 & LC80300372013152LGN00 & 14 & 0.12 & 9 \\
$6 / 1 / 2013$ & LC80300382013152LGN00 & 13 & 3.88 & 9 \\
$6 / 1 / 2013$ & LC80300392013152LGN00 & 13 & 0.53 & 9 \\
$6 / 1 / 2013$ & LC80300402013152LGN00 & 13 & 0.23 & 9 \\
$6 / 8 / 2013$ & LC80310362013159LGN00 & 13 & 0.06 & 9 \\
$6 / 8 / 2013$ & LC80310372013159LGN00 & 13 & 0.05 & 9 \\
$6 / 8 / 2013$ & LC80310382013159LGN00 & 13 & 0.12 & 9 \\
46/8/2013 & LC80310392013159LGN00 & 13 & 0.05 & 9 \\
$6 / 8 / 2013$ & LC80310402013159LGN00 & 13 & 0.01 & 9 \\
5/14/2013 & LC80320352013134LGN03 & 13 & 0.24 & 9 \\
$6 / 15 / 2013$ & LC80320362013166LGN00 & 13 & 0.2 & 9 \\
$6 / 15 / 2013$ & LC80320372013166LGN00 & 13 & 1.7 & 9 \\
$6 / 15 / 2013$ & LC80320382013166LGN00 & 13 & 0.3 & 9 \\
$6 / 15 / 2013$ & LC80320392013166LGN00 & 13 & 0.35 & 9 \\
$6 / 6 / 2013$ & LC80330342013157LGN00 & 13 & 2.15 & 9 \\
$6 / 22 / 2013$ & LC80330352013173LGN00 & 13 & 3.02 & 9 \\
$6 / 22 / 2013$ & LC80330362013173LGN00 & 13 & 2.06 & 9 \\
$6 / 6 / 2013$ & LC80330372013157LGN00 & 13 & 5.15 & 9 \\
$6 / 6 / 2013$ & LC80330382013157LGN00 & 13 & 0.09 & 9 \\
$7 / 31 / 2013$ & LC80340342013212LGN00 & 13 & 9.25 & 9 \\
$6 / 29 / 2013$ & LC80340352013180LGN00 & 13 & 5.11 & 9 \\
$6 / 29 / 2013$ & LC80340362013180LGN00 & 13 & 7.35 & 9 \\
5/28/2013 & LC80340372013148LGN00 & 13 & 2.1 & 9 \\
$6 / 13 / 2013$ & LC80340382013164LGN00 & 12 & 0.07 & 9 \\
$6 / 20 / 2013$ & LC80350342013171LGN00 & 12 & 0.06 & 9 \\
$6 / 20 / 2013$ & LC80350352013171LGN00 & 12 & 0.01 & 9 \\
$6 / 20 / 2013$ & LC80350362013171LGN00 & 12 & 0.02 & 9 \\
$6 / 20 / 2013$ & LC80350372013171LGN00 & 12 & 0.01 & 9 \\
$6 / 20 / 2013$ & LC80350382013171LGN00 & 12 & 0.04 & 9 \\
$6 / 11 / 2013$ & LC80360342013162LGN00 & 12 & 0 & 9 \\
$6 / 27 / 2013$ & LC80360352013178LGN01 & 12 & 0.01 & 9 \\
$6 / 27 / 2013$ & LC80360362013178LGN01 & 12 & 0.02 & 9 \\
$6 / 27 / 2013$ & LC80360372013178LGN01 & 12 & 0.11 & 9
\end{tabular}




\begin{tabular}{|c|c|c|c|c|}
\hline Date & Scene_ID & UTM zone & Clouds & $\begin{array}{l}\text { Quality } \\
\text { ranking }\end{array}$ \\
\hline $6 / 11 / 2013$ & LC80360382013162LGN00 & 12 & 0.18 & 9 \\
\hline $6 / 18 / 2013$ & LC80370342013169LGN01 & 12 & 0.02 & 9 \\
\hline $6 / 18 / 2013$ & LC80370352013169LGN01 & 12 & 0 & 9 \\
\hline $6 / 18 / 2013$ & LC80370362013169LGN01 & 12 & 0.02 & 9 \\
\hline $6 / 18 / 2013$ & LC80370372013169LGN01 & 12 & 0.24 & 9 \\
\hline $6 / 18 / 2013$ & LC80370382013169LGN01 & 12 & 0.13 & 9 \\
\hline $6 / 25 / 2013$ & LC80380342013176LGN00 & 12 & 0.15 & 9 \\
\hline 6/9/2013 & LC80380352013160LGN00 & 12 & 0.01 & 9 \\
\hline 6/9/2013 & LC80380362013160LGN00 & 12 & 0.06 & 9 \\
\hline $6 / 25 / 2013$ & LC80380372013176LGN00 & 11 & 0.05 & 9 \\
\hline $6 / 25 / 2013$ & LC80380382013176LGN00 & 11 & 5.93 & 9 \\
\hline $6 / 16 / 2013$ & LC80390342013167LGN00 & 11 & 0.02 & 9 \\
\hline $6 / 16 / 2013$ & LC80390352013167LGN00 & 11 & 0.26 & 9 \\
\hline $6 / 16 / 2013$ & LC80390362013167LGN00 & 11 & 0.08 & 9 \\
\hline $6 / 16 / 2013$ & LC80390372013167LGN00 & 11 & 0.34 & 9 \\
\hline $6 / 16 / 2013$ & LC80390382013167LGN00 & 11 & 6.23 & 9 \\
\hline $6 / 23 / 2013$ & LC80400342013174LGN00 & 11 & 0.12 & 9 \\
\hline $6 / 23 / 2013$ & LC80400352013174LGN00 & 11 & 0.63 & 9 \\
\hline $6 / 23 / 2013$ & LC80400362013174LGN00 & 11 & 0.96 & 9 \\
\hline $5 / 22 / 2013$ & LC80400372013142LGN01 & 11 & 27.79 & 9 \\
\hline $6 / 14 / 2013$ & LC80410342013165LGN00 & 11 & 1 & 9 \\
\hline $6 / 14 / 2013$ & LC80410352013165LGN00 & 11 & 1.05 & 9 \\
\hline $5 / 29 / 2013$ & LC80410362013149LGN00 & 11 & 2.77 & 9 \\
\hline $5 / 29 / 2013$ & LC80410372013149LGN00 & 11 & 7.66 & 9 \\
\hline $6 / 21 / 2013$ & LC80420342013172LGN00 & 11 & 1.23 & 9 \\
\hline $6 / 21 / 2013$ & LC80420352013172LGN00 & 11 & 0.18 & 9 \\
\hline $6 / 21 / 2013$ & LC80420362013172LGN00 & 11 & 1.5 & 9 \\
\hline $6 / 12 / 2013$ & LC80430342013163LGN00 & 10 & 0.49 & 9 \\
\hline $6 / 28 / 2013$ & LC80430352013179LGN00 & 10 & 11.55 & 9 \\
\hline $6 / 19 / 2013$ & LC80440342013170LGN00 & 10 & 0.47 & 9 \\
\hline
\end{tabular}


Table A2. Metadata for 57 Landsat scenes used to model flycatcher breeding habitat rangewide, Southwestern United States, 2014.

[UTM zone: Universal Transverse Mercator zone]

\begin{tabular}{|c|c|c|c|c|}
\hline Date & Scene_ID & $\begin{array}{l}\text { UTM } \\
\text { zone }\end{array}$ & Clouds & $\begin{array}{l}\text { Quality } \\
\text { ranking }\end{array}$ \\
\hline $6 / 4 / 2014$ & LC80300372014155LGN00 & 14 & 0.04 & 9 \\
\hline $6 / 4 / 2014$ & LC80300382014155LGN00 & 13 & 0.04 & 9 \\
\hline $6 / 4 / 2014$ & LC80300392014155LGN00 & 13 & 0.02 & 9 \\
\hline $6 / 4 / 2014$ & LC80300402014155LGN00 & 13 & 0.02 & 9 \\
\hline $6 / 11 / 2014$ & LC80310362014162LGN00 & 13 & 4.11 & 9 \\
\hline $5 / 10 / 2014$ & LC80310372014130LGNO0 & 13 & 0.05 & 9 \\
\hline $6 / 11 / 2014$ & LC80310382014162LGN00 & 13 & 4.39 & 9 \\
\hline $6 / 11 / 2014$ & LC80310392014162LGN00 & 13 & 0.09 & 9 \\
\hline $6 / 27 / 2014$ & LC80310402014178LGN00 & 13 & 0.26 & 9 \\
\hline $5 / 17 / 2014$ & LC80320342014137LGN00 & 13 & 0.20 & 9 \\
\hline $5 / 17 / 2014$ & LC80320352014137LGN00 & 13 & 0.01 & 9 \\
\hline $6 / 2 / 2014$ & LC80320362014153LGN00 & 13 & 0.02 & 9 \\
\hline $6 / 2 / 2014$ & LC80320372014153LGN00 & 13 & 0.46 & 9 \\
\hline $6 / 2 / 2014$ & LC80320382014153LGN00 & 13 & 0.35 & 9 \\
\hline $6 / 2 / 2014$ & LC80320392014153LGN00 & 13 & 0.00 & 9 \\
\hline $6 / 9 / 2014$ & LC80330342014160LGN00 & 13 & 0.35 & 9 \\
\hline $6 / 9 / 2014$ & LC80330352014160LGN00 & 13 & 0.04 & 9 \\
\hline $6 / 9 / 2014$ & LC80330362014160LGN00 & 13 & 0.12 & 9 \\
\hline $6 / 9 / 2014$ & LC80330372014160LGN00 & 13 & 2.49 & 9 \\
\hline $6 / 9 / 2014$ & LC80330382014160LGN00 & 13 & 0.11 & 9 \\
\hline $6 / 16 / 2014$ & LC80340342014167LGN00 & 13 & 0.87 & 9 \\
\hline $6 / 16 / 2014$ & LC80340352014167LGN00 & 13 & 0.03 & 9 \\
\hline $6 / 16 / 2014$ & LC80340362014167LGN00 & 13 & 3.60 & 9 \\
\hline $5 / 31 / 2014$ & LC80340372014151LGN00 & 13 & 4.02 & 9 \\
\hline $6 / 16 / 2014$ & LC80340382014167LGN00 & 12 & 4.07 & 9 \\
\hline $6 / 23 / 2014$ & LC80350342014174LGN00 & 12 & 18.09 & 9 \\
\hline $6 / 23 / 2014$ & LC80350352014174LGN00 & 12 & 0.61 & 9 \\
\hline $6 / 7 / 2014$ & LC80350362014158LGN00 & 12 & 0.02 & 9 \\
\hline $6 / 7 / 2014$ & LC80350372014158LGN00 & 12 & 0.01 & 9 \\
\hline $6 / 23 / 2014$ & LC80350382014174LGN00 & 12 & 0.67 & 9 \\
\hline $5 / 13 / 2014$ & LC80360342014133LGN00 & 12 & 1.62 & 9 \\
\hline $6 / 14 / 2014$ & LC80360352014165LGN00 & 12 & 0.01 & 9 \\
\hline $6 / 14 / 2014$ & LC80360362014165LGN00 & 12 & 0.03 & 9 \\
\hline $6 / 14 / 2014$ & LC80360372014165LGN00 & 12 & 0.45 & 9 \\
\hline $6 / 14 / 2014$ & LC80360382014165LGN00 & 12 & 0.34 & 9 \\
\hline $6 / 5 / 2014$ & LC80370342014156LGN01 & 12 & 0.73 & 9 \\
\hline $6 / 5 / 2014$ & LC80370352014156LGN01 & 12 & 0.01 & 9 \\
\hline
\end{tabular}




\begin{tabular}{|c|c|c|c|c|}
\hline Date & Scene_ID & $\begin{array}{l}\text { UTM } \\
\text { zone }\end{array}$ & Clouds & $\begin{array}{l}\text { Quality } \\
\text { ranking }\end{array}$ \\
\hline $6 / 21 / 2014$ & LC80370362014172LGN00 & 12 & 0.29 & 9 \\
\hline $6 / 21 / 2014$ & LC80370372014172LGN00 & 12 & 0.28 & 9 \\
\hline $6 / 21 / 2014$ & LC80370382014172LGN00 & 12 & 0.08 & 9 \\
\hline $6 / 28 / 2014$ & LC80380342014179LGN00 & 12 & 0.06 & 9 \\
\hline $6 / 28 / 2014$ & LC80380352014179LGN00 & 12 & 0.01 & 9 \\
\hline $6 / 28 / 2014$ & LC80380362014179LGN00 & 12 & 0.06 & 9 \\
\hline $6 / 28 / 2014$ & LC80380372014179LGN00 & 11 & 0.04 & 9 \\
\hline $6 / 28 / 2014$ & LC80380382014179LGN00 & 11 & 1.79 & 9 \\
\hline $6 / 19 / 2014$ & LC80390342014170LGN00 & 11 & 0.04 & 9 \\
\hline $6 / 19 / 2014$ & LC80390352014170LGN00 & 11 & 0.26 & 9 \\
\hline $6 / 19 / 2014$ & LC80390362014170LGN00 & 11 & 0.06 & 9 \\
\hline $6 / 19 / 2014$ & LC80390372014170LGN00 & 11 & 0.32 & 9 \\
\hline $6 / 19 / 2014$ & LC80390382014170LGN00 & 11 & 1.07 & 9 \\
\hline $5 / 25 / 2014$ & LC80400342014145LGN00 & 11 & 0.36 & 9 \\
\hline $6 / 10 / 2014$ & LC80400352014161LGN00 & 11 & 2.04 & 9 \\
\hline $6 / 10 / 2014$ & LC80400362014161LGN00 & 11 & 0.41 & 9 \\
\hline $5 / 25 / 2014$ & LC80400372014145LGN00 & 11 & 20.97 & 9 \\
\hline $6 / 17 / 2014$ & LC80410342014168LGN00 & 11 & 2.11 & 9 \\
\hline $6 / 17 / 2014$ & LC80410352014168LGN00 & 11 & 1.13 & 9 \\
\hline $6 / 17 / 2014$ & LC80410362014168LGN00 & 11 & 0.93 & 9 \\
\hline $6 / 17 / 2014$ & LC80410372014168LGN00 & 11 & 13.09 & 9 \\
\hline $6 / 24 / 2014$ & LC80420342014175LGN00 & 11 & 1.25 & 9 \\
\hline $6 / 24 / 2014$ & LC80420352014175LGN00 & 11 & 0.23 & 9 \\
\hline $6 / 24 / 2014$ & LC80420362014175LGN00 & 11 & 15.83 & 9 \\
\hline $6 / 15 / 2014$ & LC80430342014166LGN00 & 10 & 3.53 & 9 \\
\hline $5 / 30 / 2014$ & LC80430352014150LGN00 & 10 & 9.00 & 9 \\
\hline $6 / 22 / 2014$ & LC80440342014173LGN00 & 10 & 30.02 & 9 \\
\hline
\end{tabular}


Table A3. Metadata for 57 Landsat scenes used to model flycatcher breeding habitat rangewide, Southwestern United States, 2015.

[UTM zone: Universal Transverse Mercator zone]

\begin{tabular}{|c|c|c|c|c|c|}
\hline $\begin{array}{l}\text { Path/ } \\
\text { row }\end{array}$ & Scene_ID & $\begin{array}{l}\text { Acquisition } \\
\text { date }\end{array}$ & $\begin{array}{l}\text { UTM } \\
\text { zone }\end{array}$ & Clouds & $\begin{array}{l}\text { Quality } \\
\text { ranking }\end{array}$ \\
\hline 3038 & LC80300382015206LGN00 & $7 / 25 / 2015$ & 13 & 0.09 & 9 \\
\hline 3039 & LC80300392015206LGN00 & $7 / 25 / 2015$ & 13 & 0.80 & 9 \\
\hline 3040 & LC80300402015158LGN00 & $6 / 07 / 2015$ & 13 & 1.43 & 9 \\
\hline 3136 & LC80310362015181LGN00 & $6 / 30 / 2015$ & 13 & 0.06 & 9 \\
\hline 3137 & LC80310372015165LGN00 & $6 / 14 / 2015$ & 13 & 0.08 & 9 \\
\hline 3138 & LC80310382015165LGN00 & $6 / 14 / 2015$ & 13 & 0.14 & 9 \\
\hline 3139 & LC80310392015197LGN00 & $7 / 16 / 2015$ & 13 & 0.17 & 9 \\
\hline 3140 & LC80310402015197LGN00 & $7 / 16 / 2015$ & 13 & 0.07 & 9 \\
\hline 3235 & LC80320352015172LGN00 & $6 / 21 / 2015$ & 13 & 0.00 & 9 \\
\hline 3236 & LC80320362015172LGN00 & $6 / 21 / 2015$ & 13 & 0.00 & 9 \\
\hline 3237 & LC80320372015172LGN00 & $6 / 21 / 2015$ & 13 & 0.51 & 9 \\
\hline 3238 & LC80320382015172LGN00 & $6 / 21 / 2015$ & 13 & 0.38 & 9 \\
\hline 3239 & LC80320392015172LGN00 & $6 / 21 / 2015$ & 13 & 0.21 & 9 \\
\hline 3334 & LC80330342015227LGN00 & $8 / 15 / 2015$ & 13 & 1.20 & 9 \\
\hline 3335 & LC80330352015227LGN00 & $8 / 15 / 2015$ & 13 & 0.88 & 9 \\
\hline 3336 & LC80330362015227LGN00 & $8 / 15 / 2015$ & 13 & 0.31 & 9 \\
\hline 3337 & LC80330372015227LGN00 & $8 / 15 / 2015$ & 13 & 5.51 & 9 \\
\hline 3338 & LC80330382015163LGN00 & $6 / 12 / 2015$ & 13 & 0.28 & 9 \\
\hline 3434 & LC80340342015154LGN00 & $6 / 03 / 2015$ & 13 & 1.82 & 9 \\
\hline 3435 & LC80340352015170LGN00 & $6 / 19 / 2015$ & 13 & 0.26 & 9 \\
\hline 3436 & LC80340362015170LGN00 & $6 / 19 / 2015$ & 13 & 0.13 & 9 \\
\hline 3437 & LC80340372015170LGN00 & $6 / 19 / 2015$ & 13 & 0.31 & 9 \\
\hline 3438 & LC80340382015170LGN00 & $6 / 19 / 2015$ & 12 & 0.03 & 9 \\
\hline 3534 & LC80350342015177LGN00 & $6 / 26 / 2015$ & 12 & 1.20 & 9 \\
\hline 3535 & LC80350352015177LGN00 & $6 / 26 / 2015$ & 12 & 4.99 & 9 \\
\hline 3536 & LC80350362015177LGN00 & $6 / 26 / 2015$ & 12 & 10.50 & 9 \\
\hline 3537 & LC80350372015177LGN00 & $6 / 26 / 2015$ & 12 & 6.47 & 9 \\
\hline 3538 & LC80350382015177LGN00 & $6 / 26 / 2015$ & 12 & 0.42 & 9 \\
\hline 3634 & LC80360342015168LGN00 & $6 / 17 / 2015$ & 12 & 0.03 & 9 \\
\hline 3635 & LC80360352015168LGN00 & $6 / 17 / 2015$ & 12 & 0.00 & 9 \\
\hline 3636 & LC80360362015168LGN00 & $6 / 17 / 2015$ & 12 & 0.02 & 9 \\
\hline 3637 & LC80360372015168LGN00 & $6 / 17 / 2015$ & 12 & 0.28 & 9 \\
\hline 3638 & LC80360382015152LGN00 & $6 / 1 / 2015$ & 12 & 0.20 & 9 \\
\hline 3734 & LC80370342015159LGN00 & $6 / 8 / 2015$ & 12 & 0.80 & 9 \\
\hline 3735 & LC80370352015191LGN00 & $7 / 10 / 2015$ & 12 & 0.73 & 9 \\
\hline 3736 & LC80370362015175LGN00 & $6 / 24 / 2015$ & 12 & 6.35 & 9 \\
\hline 3737 & LC80370372015191LGN00 & $7 / 10 / 2015$ & 12 & 3.07 & 9 \\
\hline 3738 & LC80370382015191LGN00 & $7 / 10 / 2015$ & 12 & 2.72 & 9 \\
\hline
\end{tabular}




\begin{tabular}{cccccc}
\hline $\begin{array}{c}\text { Path/ } \\
\text { row }\end{array}$ & Scene_ID & $\begin{array}{c}\text { Acquisition } \\
\text { date }\end{array}$ & $\begin{array}{c}\text { UTM } \\
\text { zone }\end{array}$ & Clouds & $\begin{array}{c}\text { Quality } \\
\text { ranking }\end{array}$ \\
\hline 3834 & LC80380342015198LGN00 & $7 / 17 / 2015$ & 12 & 0.14 & 9 \\
3835 & LC80380352015182LGN00 & $70 / 1 / 2015$ & 12 & 0.01 & 9 \\
3836 & LC80380362015198LGN00 & $7 / 17 / 2015$ & 12 & 0.76 & 9 \\
3837 & LC80380372015166LGN00 & $6 / 15 / 2015$ & 11 & 0.05 & 9 \\
3838 & LC80380382015166LGN00 & $6 / 15 / 2015$ & 11 & 1.37 & 9 \\
3934 & LC80390342015173LGN00 & $6 / 22 / 2015$ & 11 & 0.03 & 9 \\
3935 & LC80390352015173LGN00 & $6 / 22 / 2015$ & 11 & 0.26 & 9 \\
3936 & LC80390362015173LGN00 & $6 / 22 / 2015$ & 11 & 0.07 & 9 \\
3937 & LC80390372015173LGN00 & $6 / 22 / 2015$ & 11 & 0.73 & 9 \\
4034 & LC80400342015196LGN00 & $7 / 15 / 2015$ & 11 & 0.09 & 9 \\
4035 & LC80400352015196LGN00 & $7 / 15 / 2015$ & 11 & 0.32 & 9 \\
4036 & LC80400362015196LGN00 & $7 / 15 / 2015$ & 11 & 0.34 & 9 \\
4037 & LC80400372015196LGN00 & $7 / 15 / 2015$ & 11 & 0.82 & 9 \\
4134 & LC80410342015171LGN00 & $6 / 20 / 2015$ & 11 & 2.41 & 9 \\
4135 & LC80410352015171LGN00 & $6 / 20 / 2015$ & 11 & 0.86 & 9 \\
4136 & LC80410362015171LGN00 & $6 / 20 / 2015$ & 11 & 0.77 & 9 \\
4137 & LC80410372015171LGN00 & $6 / 20 / 2015$ & 11 & 3.04 & 9 \\
4234 & LC80420342015194LGN00 & $7 / 13 / 2015$ & 11 & 0.86 & 9 \\
4235 & LC80420352015194LGN00 & $7 / 13 / 2015$ & 11 & 0.16 & 9 \\
4236 & LC80420362015226LGN00 & $8 / 14 / 2015$ & 11 & 0.25 & 9 \\
\hline & & & & & \\
\hline
\end{tabular}


Table A4. Metadata for habitat-time-series analysis of Virgin River, Nevada and Arizona.

[Satellite model was used to predict flycatcher habitat at a 40-percent probability threshold. For this analysis, two Landsat scenes were mosaicked together each year (paths/rows [PRs] 3934 and 3935)]

\begin{tabular}{|c|c|c|c|c|}
\hline Year & $\begin{array}{c}\text { PR } 3934 \\
\text { (Julian date) }\end{array}$ & $\begin{array}{l}\text { Acquisition } \\
\text { date }\end{array}$ & $\begin{array}{c}\text { PR } 3935 \\
\text { (Julian date) }\end{array}$ & $\begin{array}{l}\text { Acquisition } \\
\text { date }\end{array}$ \\
\hline 1986 & 221 & 8.8 .86 & 205 & 7.23 .86 \\
\hline 1987 & 160 & 6.9 .87 & 160 & 6.9 .87 \\
\hline 1988 & 163 & 6.11 .88 & 195 & 7.13 .88 \\
\hline 1989 & 165 & 6.14 .89 & 181 & 6.30 .89 \\
\hline 1990 & 184 & 7.2 .90 & 184 & 7.2.90 \\
\hline 1991 & 171 & 6.20 .91 & 171 & 6.20 .91 \\
\hline 1992 & 182 & 6.30 .92 & 182 & 6.30 .92 \\
\hline 1993 & 192 & 7.11 .93 & 192 & 7.11 .93 \\
\hline 1994 & 179 & 6.27 .94 & 179 & 6.27 .94 \\
\hline 1995 & 182 & 7.1 .95 & 182 & 7.1 .95 \\
\hline 1996 & 169 & 6.17 .96 & 169 & 6.17 .96 \\
\hline 1997 & 187 & 7.6.97 & 171 & 6.20 .97 \\
\hline 1998 & 174 & 6.23 .98 & 158 & 7.7.98 \\
\hline 1999 & 177 & 6.26 .99 & 177 & 6.26 .99 \\
\hline 2000 & 180 & 6.28 .00 & 148 & 5.27 .00 \\
\hline 2001 & 166 & 6.15 .01 & 166 & 6.15 .01 \\
\hline 2002 & 169 & 6.18 .02 & 169 & 6.18 .02 \\
\hline 2003 & 172 & 6.21 .03 & 172 & 6.21 .03 \\
\hline 2004 & 159 & 6.7 .04 & 159 & 6.7 .04 \\
\hline 2005 & 177 & 6.26 .05 & 177 & 6.26 .05 \\
\hline 2006 & 180 & 6.29 .06 & 180 & 6.29 .06 \\
\hline 2007 & 167 & 6.16 .07 & 167 & 6.16 .07 \\
\hline 2008 & 170 & 6.18 .08 & 170 & 6.18 .08 \\
\hline 2009 & 172 & 6.21 .09 & 172 & 6.21 .09 \\
\hline 2010 & 175 & 6.24 .10 & 175 & 6.24 .10 \\
\hline 2011 & 178 & 6.27 .11 & 178 & 6.27 .11 \\
\hline 2013 & 167 & 6.16 .13 & 167 & 6.16 .13 \\
\hline 2014 & 170 & 6.19 .14 & 170 & 6.19 .14 \\
\hline 2015 & 173 & 6.22 .15 & 173 & 6.22 .15 \\
\hline
\end{tabular}


Table A5. Metadata for Landsat scenes used in habitat-time-series analysis, by year, upper Gila River, Arizona and California.

[All scenes are path 35 and row 37, UTM Zone 12. NA, not available]

\begin{tabular}{|c|c|c|}
\hline Year & $\begin{array}{c}\text { Julian } \\
\text { day }\end{array}$ & $\begin{array}{c}\text { Month and } \\
\text { day }\end{array}$ \\
\hline 1986 & 161 & June 10 \\
\hline 1987 & 180 & June 28 \\
\hline 1988 & 167 & June 15 \\
\hline 1989 & 169 & June 18 \\
\hline 1990 & 236 & August 24 \\
\hline 1991 & 159 & June 8 \\
\hline 1992 & 178 & June 26 \\
\hline 1993 & 180 & June 29 \\
\hline 1994 & 167 & June 16 \\
\hline 1995 & 170 & June 19 \\
\hline 1996 & 157 & June 5 \\
\hline 1997 & 175 & June 24 \\
\hline 1998 & 178 & June 27 \\
\hline 1999 & 181 & June 30 \\
\hline 2000 & 168 & June 16 \\
\hline 2001 & 170 & June 19 \\
\hline 2002 & 173 & June 22 \\
\hline 2003 & 176 & June 25 \\
\hline 2004 & 163 & June 11 \\
\hline 2005 & 165 & June 14 \\
\hline 2006 & 168 & June 17 \\
\hline 2007 & 123 & May 3 \\
\hline 2008 & 158 & June 6 \\
\hline 2009 & 128 & May 8 \\
\hline 2010 & 147 & May 26 \\
\hline 2011 & 166 & June 15 \\
\hline 2012 & NA & NA \\
\hline 2013 & 171 & June 20 \\
\hline 2014 & 158 & June 7 \\
\hline 2015 & 177 & June 26 \\
\hline
\end{tabular}




\section{Appendix B. Normalized Difference Vegetation Index (NDVI) Conversions for Landsat 8}

\section{Landsat 5}

The flycatcher satellite model was developed with imagery acquired from the Landsat 5 Thematic Mapper sensor that was in continuous operation from 1984 through 2011. No adjustments to Landsat 5 images are required before their use in the satellite model; just follow a few simple steps:

1. Preview and download the desired imagery from the EROS Data Center with the GLOVIS tool (http://glovis.usgs.gov/),

2. calculate NDVI with bands 3 and 4 ,

3. Create the three vegetation variables, and

4. Apply equation 1 (see section, "Methods").

It is not advisable at this time to adjust Landsat 5 imagery to top-of-atmosphere (TOA) reflectance (Chander and others, 2009) because equation 1 will produce unreliable results.

If one selects an image that was acquired with Landsat 8 (from late 2012 to present), the image must first be adjusted to TOA reflectance before calculating NDVI. Following TOA adjustment and NDVI calculation, a simple two-step regression is applied to the NDVI values to convert them to Landsat 5 NDVI values. Without applying the TOA adjustment or regressions, the satellite model will not produce results similar to those from 1984 to 2011. Some of the material presented in the following section (eq. B1) was published in a previous study (Hatten, 2014). However, a significant alteration has been made (eq. B2 is new) in order for the flycatcher satellite model to run correctly on Landsat 8. Specifically, Landsat 5 uses bands 3 and 4 to calculate NDVI, whereas Landsat 8 uses bands 4 and 5. The bandwidth of Band 3 (red) for Landsat 5 is $0.63-0.69 \mu \mathrm{m}$, whereas band 4 (reflected IR) is $0.76-0.90 \mu \mathrm{m}$. In contrast, the Landsat 8 red band (band 4) is $0.64-0.67 \mu \mathrm{m}$, whereas its reflected IR band (band 5) is $0.85-0.88$ $\mu \mathrm{m}$. These differences in bandwidth present problems when calculating NDVI because they produce slightly different NDVI values that affect model probabilities used to produce flycatcher habitat suitability maps.

To successfully run the flycatcher satellite model after 2011 (Landsat 5 failed), the Landsat 8 NDVI values were calibrated against those of Landsat 5. Landsat 5 stopped working during autumn 2011, whereas Landsat 8 did not become operational until May 2013, making calibrating the two Landsat NDVI values impossible. A workaround was built by creating a statistical bridge from Landsat 8 to 7 NDVI values for 2013, and then from Landsat 7 to 5 NDVI values for 2011. This was accomplished by first adjusting Landsat 8 and 7 to TOA reflectance (Chander and others, 2009), but not adjusting Landsat 5 to TOA (rationale provided below), and applying a two-step linear regression; step 1 converted Landsat 8 to Landsat 7 NDVI values, and step two converted Landsat 7 to Landsat 5 NDVI values. Following these corrections, the three vegetation variables were created with the modified NDVI values and the flycatcher model was created by applying equation 1 . Testing of these methods at multiple locations and times showed that they produced consistent results, whereas unadjusted imagery produced inconsistent results. 
The NDVI adjustment procedure was not straightforward because Landsat 7 has an ongoing problem with one of its sensor arrays that produces no-data stripes in certain areas (this is why the use of Landsat 7 data is not recommended unless absolutely necessary). Every Landsat 7 scene has an error-free path (a large strip with no striping problems), so a stripe-free area was selected along the upper Gila River (fig. B1; Area 1) and a regression was developed between Landsat 8 and 7 NDVI values. I switched areas when I converted Landsat 7 to 5 NDVI values (fig. B1; Area 2) because of a better match on acquisition dates.

After converting Landsat 7 and 8 images to TOA reflectance, NDVI was calculated for both images. Next, 5,000 random points were generated around the Salt River where there was much spectral variability because of desert and riparian areas. A geographic information system was used to attribute the 5,000 random points with Landsat 7 and Landsat 8 NDVI values obtained at the same locations. Next, linear regression was used to predict Landsat 7 NDVI with Landsat 8 NDVI (fig. B1; Area 2). There were significant differences between Landsat 7 and 8 NDVI values before conversion, but the difference became very small after converting Landsat 8 to Landsat 7 NDVI values with the following regression equation:

$$
N E \text { pre }=-0.239+(1.041 \times N C)
$$

where

$$
\begin{aligned}
N E \text { pre } & \text { is predicted Landsat } 7 \text { NDVI and } \\
N C & \text { is Landsat } 8 \text { NDVI. }
\end{aligned}
$$

This simple equation explained 94 percent of the variability between the two NDVI datasets and successfully converted Landsat 8 NDVI to Landsat 7 NDVI. The means and medians of the NDVI locations $(n=5,000)$ were quite different before conversion, but almost identical following conversion (fig. B3A). The mean Landsat 8 NDVI was 0.2269 and the mean Landsat 7 NDVI was -0.0029 prior to conversion, but following conversion with equation B1, the Landsat 8 mean NDVI was -0.0028 .

\section{Converting Landsat 7 NDVI to Landsat 5 NDVI}

An almost identical procedure was used to convert between Landsat 7 and 5 NDVI values as those used to convert between Landsat 8 to 7 NDVI values except that Landsat 5 was not converted to TOA. Through experimental conversions of NDVI between sensors, I learned that the flycatcher satellite model simulations only produced accurate predictions of habitat when I did not adjust Landsat 5 to TOA before applying a correction factor. The reason for this is that the original satellite model of flycatcher habitat did not apply TOA correction (Hatten and Paradzick, 2003); thus, converting it retrospectively and then applying an NDVI correction between sensors resulted in unexpected results, such as a halo effect surrounding patches. Therefore, it is not advised to apply TOA correction to Landsat 5 imagery when applying the NDVI correction. 
An area along the upper Gila River was used when NDVI values were converted between Landsat 7 and 5 (fig. B1; Area 1). After generating 5,000 random points in Area 1 and attributing them with Landsat 7 NDVI (corrected to TOA) and Landsat 5 (not adjusted to TOA) NDVI values, a linear regression explained 0.93 percent of the variability in NDVI (fig. B3B) with the following equation:

$$
N T \_ \text {pre }=0.102+\left(0.897 \times N E \_ \text {pre }\right)
$$

where

$$
\begin{array}{ll}
N T \text { pre } & \text { is predicted Landsat } 5 \text { NDVI, and } \\
N E \text { pre } & \text { is predicted Landsat } 7 \text { NDVI. }
\end{array}
$$

The means and medians of the two NDVI layers were quite different before conversion, but were almost identical after conversion (fig. B3B). Specifically, the mean NDVI value for Landsat 7 was -0.0858 compared to the Landsat 5 mean of 0.0247 , but the Landsat 7 mean NDVI was 0.025 after conversion. 


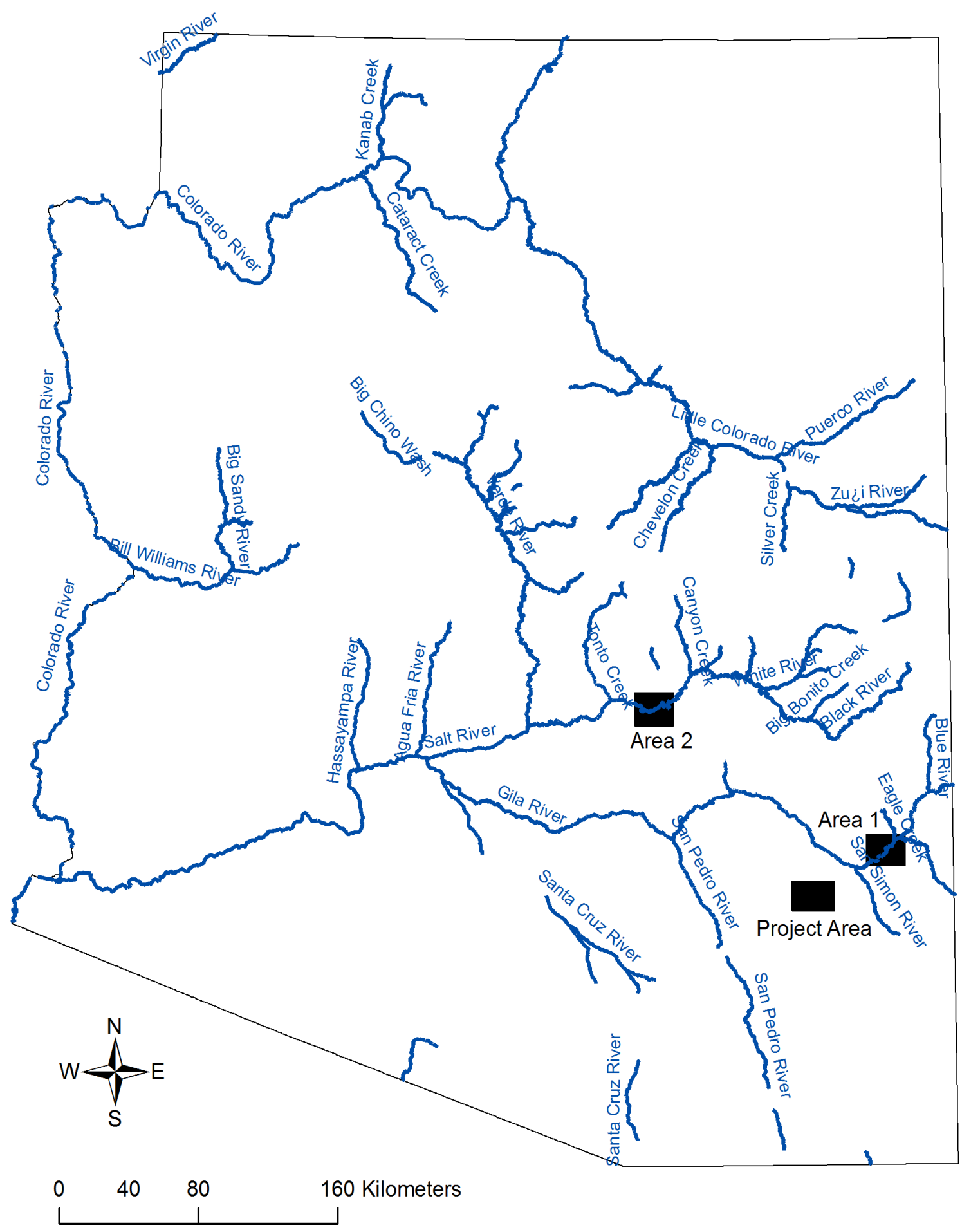

Figure B1. Map showing locations of areas 1 and 2 used in normalized difference vegetation index (NDVI) adjustments between sensors. Areas 1 and 2 were locations where 5,000 random points along the river channels were used to adjust Landsat 8 NDVI values to match Landsat 7 and $5 \mathrm{NDVI}$ values. Project Area in this figure refers to a previous modeling effort where some of the methodologies presented in this report were originally developed (see Hatten, 2014). 

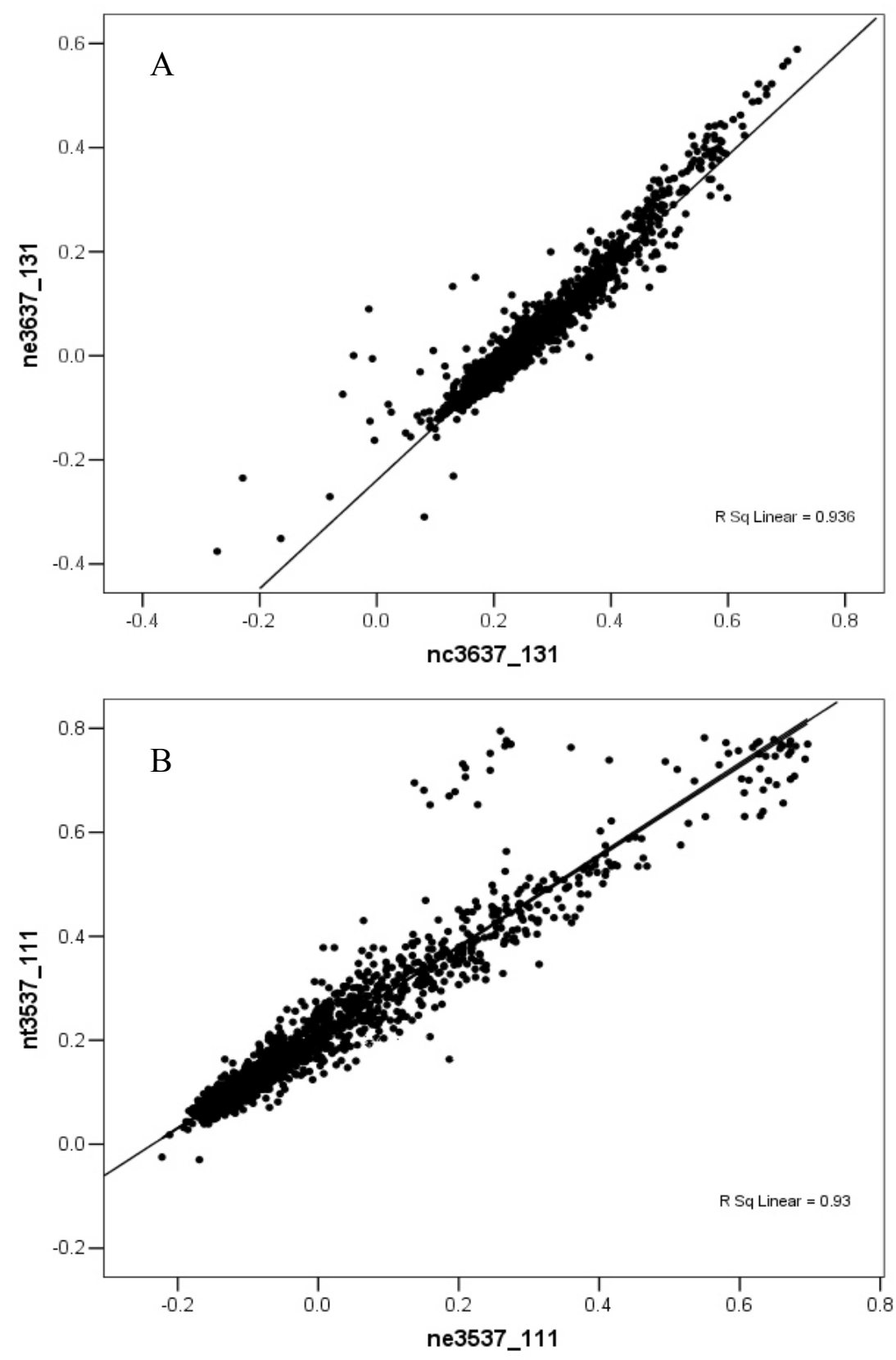

Figure B2. (A) Relation between Landsat 8 and 7 normalized difference vegetation index (NDVI), after adjusting to top-of-atmosphere [TOA] reflectance; and (B) relation between Landsat 7 and $5 \mathrm{NDVI}$, after adjusting to TOA reflectance. Landsat 8 and 7 images (A) were acquired in 2013, and Landsat 7 and 5 scenes (B) were acquired in 2011. nc, Landsat $8 \mathrm{NDVl}$; ne, Landsat $7 \mathrm{NDVl}$; nt, Landsat 5 NDVI. NDVI values in (A) were acquired in Area 1 (fig. B1) while NDVI values in (B) were acquired in Area 2 (fig. B1). The numbers 3537 or 3637 refer to the different path/row numbers of each scene. 

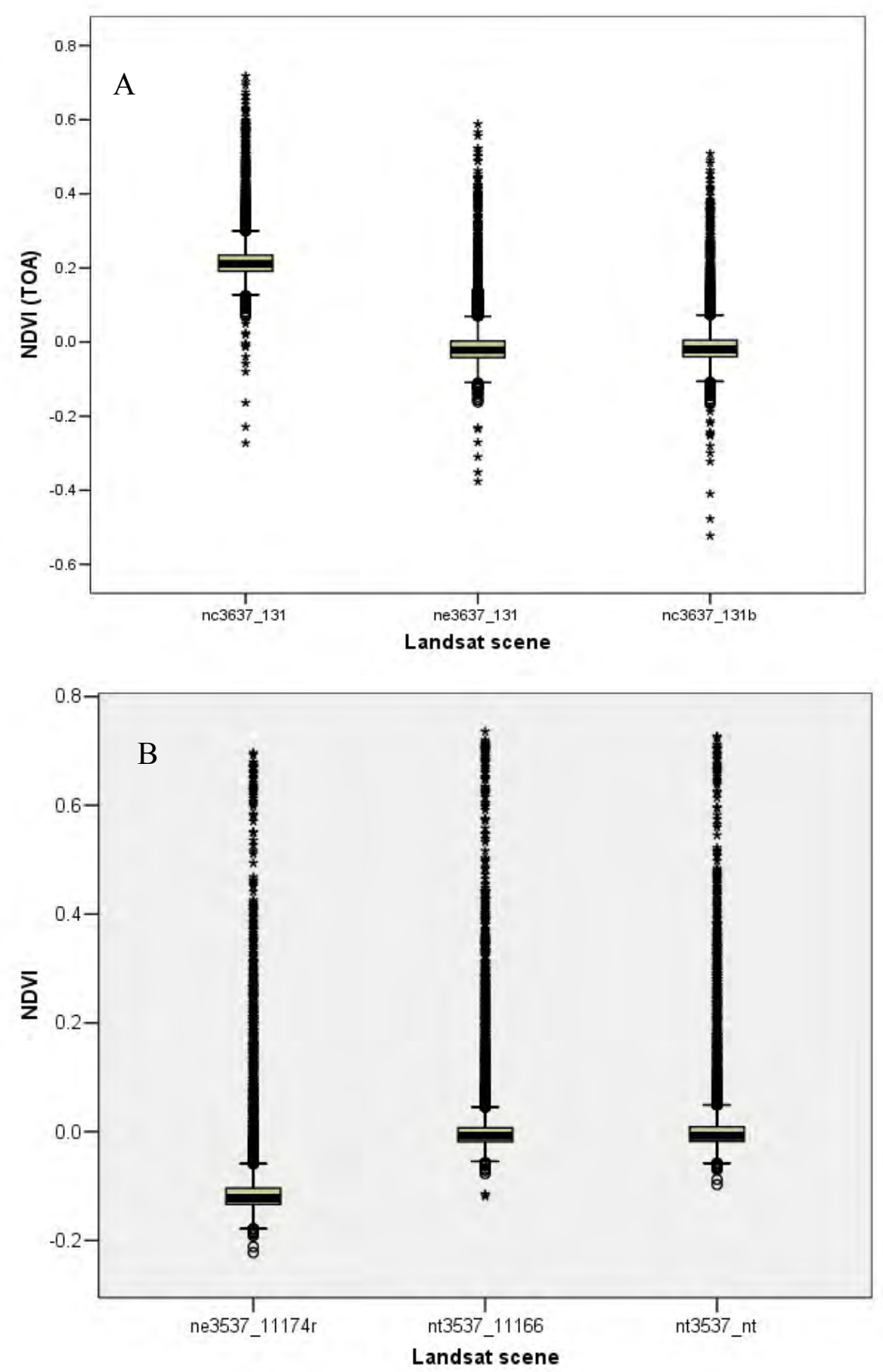

Figure B3. (A) Distribution of Landsat 8 normalized difference vegetation index (NDVI) before (nc3637_131) and after (nc3637_131b) conversion to Landsat 7 (ne3637_131) NDVI, using equation B1; and (B) distribution of Landsat 7 NDVI before (ne3537_11174r) and after (nt3537_nt) conversion to Landsat 5 (nt3537_11166) NDVI, using equation B2. Landsat image ne3537_11174r was converted to topof-atmosphere (TOA) reflectance before NDVI calculations were made, whereas nt3537_11166 was not converted to TOA. 
Publishing support provided by the U.S. Geological Survey

Science Publishing Network, Tacoma Publishing Service Center

For more information concerning the research in this report, contact the Director, Western Fisheries Research Center U.S. Geological Survey

6505 NE 65th Street

Seattle, Washington 98115

http://wfrc.usgs.gov/ 
